\title{
Oregon State University TRIgA Reactor ANNUAL Report
}

To satisfy the requirements of:

A. U.S. Nuclear Regulatory Commission License R-106 (Docket No. 50-234), Section $6.7(e)$ of the Technical Specifications, for the period July 1 , 1978 through June 30, 1979.

B. U.S. Department of Energy Fuel Fabrication Contract No. EY-76-C-06-1953, for the period July 1, 1978 through June 30, 1979.

C. Oregon Department of Energy, DOE Rule No. 30-010, for the period July 1, 1978 through June 30, 1979.

Written by:

T.V. Anderson, Reactor Supervisor

A.G. Johnson, Health Physicist

S.L. Bennett, Radiation Specialist

J.C. Ringle, Assistant Reactor Administrator

Submitted by:

C.H. Wang, Reactor Administrator

Radiation Center

Oregon State University

Corvallis, Oregon 97331

Telephone: 503-751-2341

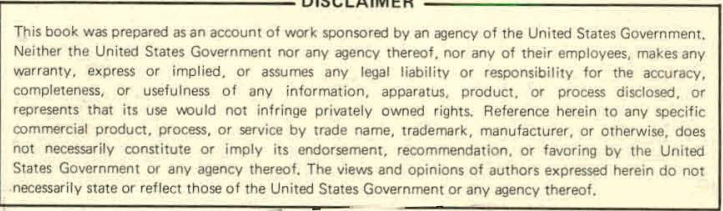

tates Government or any agency thereof. The views and opinions of authors expressed herein do not States Government of any agency thereot. The views and opinions of authors express

August 31,1979 


\section{DISCLAIMER}

This report was prepared as an account of work sponsored by an agency of the United States Government. Neither the United States Government nor any agency Thereof, nor any of their employees, makes any warranty, express or implied, or assumes any legal liability or responsibility for the accuracy, completeness, or usefulness of any information, apparatus, product, or process disclosed, or represents that its use would not infringe privately owned rights. Reference herein to any specific commercial product, process, or service by trade name, trademark, manufacturer, or otherwise does not necessarily constitute or imply its endorsement, recommendation, or favoring by the United States Government or any agency thereof. The views and opinions of authors expressed herein do not necessarily state or reflect those of the United States Government or any agency thereof. 


\section{DISCLAIMER}

Portions of this document may be illegible in electronic image products. Images are produced from the best available original document. 


\section{TABLE OF CONTENTS}

page

I. InTRODUCTION AND SUMMARY . . . . . . . . . . . . I-1

A. INTRODUCTION TO OREGON STATE TRIGA REACTOR ANNUAL REPORT. . I

B. SUMMARY OF OSTR USE DURING REPORTING PERIOD . . . . . . . I I I

C. SUMMARY OF OSTR ENVIRONMENTAL AND RADIATION PROTECTION DATA I-3

1. Liquid Waste Date ................ I-3

2. Gaseous Waste Data................ I I-4

3. Solid Waste.................. I I 4

4. Radiation Exposure Received by Facility Personnel and Visitors (in mRem)................. I-5

5. Number of Area and Offsite Environmental Monitoring Samples Evaluated ............... I-5

II. General Information $\ldots \ldots \ldots \ldots \ldots \ldots$ iI-

A. RAdiATION CEnTER. ..................... II-1

B. FACULTY MEMBERS HOUSED AT THE RADIATION CENTER. . . . . . . II-2

C. RESEARCH PERSONNEL HOUSED AT THE RADIATION CENTER . . . . . II-3

1. Post-Doctorate Research Associates. . . . . . . . II-3

2. Graduate Students ............... . II-3

3. Visiting Scientists and Trainees. . . . . . . . . II-5

D. CLASSIFIED STAFF AT THE RADIATION CENTER. . . . . . . . . II-5

E. REACTOR OPERATIONS STAFF. ................. . . II-5.

F. REACTOR OPERATIONS COMMITTEE. . . . . . . . . . . II-6

G. RADIATION SAFETY COMMITTEE. . . . . . . . . . . II-6 
page

III Operational Data $\ldots \ldots \ldots \ldots \ldots \ldots \ldots \ldots$ ili-1

A. REVIEW. . . . . . . . . . . . . . . . . . III-1

B. OPERATING STATISTICS. . . . . . . . . . . . . III-5

C. EXPERIMENTS PERFORMED . . . . . . . . . . . . . . . . III 9

D. UNPLANNED SHUTDOWNS ...................... . . III-12

E. CHANGES IN FACILITY ................... . . III-12

1. 10 CFR 50.59 Changes............... III-12

2. Other Changes ................ . III 12

3. Planned Changes ................ III-13

F. MAINTENANCE AND SURVEILLANCE. . . . . . . . . . . III-16

1. Maintenance ................. III-16

2. Tests and Inspections.............. III-17

G. REPORTABLE OCCURRENCE ................ III-17

IV. UTILIZATION DATA . . . . . . . . . . . . . . . . . . . . IV-1

A. TEACHING PROGRAMS .................... . . . IV- I

B. RESEARCH PROGRAMS .................... . . . IV-8

C. PUBLICATIONS RESULTING FROM OSTR OPERATIONS THAT WERE
REPORTED TO THE RADIATION CENTER.......
.

1. Publications in Print.............. IV-15

2. Publications in Press.............. IV-16

3. Reports and Papers. . . . . . . . . . . . IV-16.

D. COMMERCIAL OR NON-ACADEMIC UTILIZATION. . . . . . . . IV-17

E. PUBLIC RELATIONS. . . . . . . . . . . . . . . IV-17

F. PlanNED ChANGES IN UTILIZATION. . . . . . . . . . . . IV-17 
V. Environmental and Radiation Protection Data; JULY 1, 1978 - JUNE 30, 1979 . . . . . . . . . . V-1

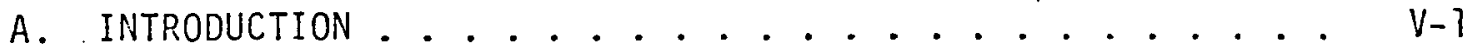

B. A SUMMARY OF THE NATURE AND AMOUNT OF RADIOACTIVE EFFLUENTS RELEASED OR DISCHARGED TO THE ENVIRONS BEYOND THE EFFECTIVE CONTROL OF THE LICENSEE AS MEASURED AT OR PRIOR TO THE POIMT OF SUCH RELEASE OR DISCHARGE .......... V $\mathrm{V}-1$

1. Liquid Waste (summarized on a monthly basis) . . . . V-l

(a) The radioactivity discharged during the reporting period .......... $v-1$

(1) The total estimated quantity of radioactivity released (in curies) ..... V-l

(2) The detectable radionuclides present in this waste.......... $V$-2

(3) An estimate of the specific activity for each detectable radionuclide present if the specific activity of the released material after dilution was greater than $1 \times 10^{-7}$ microcuries/cubic centimeter. .

(4) A summary of the total release (in curies) for each radionuclide determined in (2) above for the reporting period, based on representative isotopic analysis .....

(5) The estimated average concentration of the released radioactive material at the point of release for the reporting period (in terms of microcuries/cubic centimeter) and the fraction of the applicable MPC value........ V-2

(b) The total volume (in gallons) of effluent water (including diluent) released during each period of release ........... $\mathrm{V}$ - . 
2. Gaseous Waste (summarized on a monthly basis) . . . V-2

(a) The radioactivity discharged during the reporting period.......... $v-2$

(1). The total estimated quantity of radioactivity released (in curies) determined by an appropriate sampling and counting method

(2) The detectable radionuclides present in this waste .......... V-3

(3) The total estimated quantity of Argon-41 released (in curies) during the reporting period based on data from an appropriate monitoring system ..... V-3

(4) The estimated average atmospheric diluted concentration of Argon-41 released during the reporting period (in terms of microcuries/cubic centimeter) and the fraction of the applicable MPC value............. v-3

(5) The total estimated quantity of radioactivity in particulate form with half-lives greater than eight days (in curies) released during the reporting period, as determined by an appropriate particulate monitoring system. . . . . . . ..... V-3

(6) The average concentration of radioactive. particulates with half-lives greater than eight days (in microcuries/cubic centimeter) released during the reporting period ........ $V-3$

(7) An estimate of the average concentration of other significant radionuclides present in the gaseous waste discharge (in terms of microcuries/cubic centimeter) and the fraction of the applicable MPC value for the reporting period, if the estimated release was greater than $20 \%$ of the applicable MPC ...... 
3. Solid laste (summarized on an annual basis). . . V-4

(a). The radioactivity discharged during the reporting period ......... V-4

(1) The total amount of solid waste packaged (in cubic feet) ...... V-4

(2) The detectable radionuclides present in this waste........ $V-4$

(3) The total radioactivity in the solid waste (in curies).......... . V-4

(b) The dates of shipment and disposition (if shipped off-site)........... V V-4

C. AN ANNUAL SUMMARY OF THE RADIATION EXPOSURE RECEIVED BY FACILITY PERSONNEL AND BY VISITORS IN TERMS OF THE AVERAGE RADIATION EXPOSURE PER INDIVIDUAL AND THE GREATEST EXPOSURE PER INDIVIDUAL FOR EACH OF THE TWO GROUPS .................... $\mathrm{V}-4$

D. AN ANNUAL SUMAARY OF THE RADIATION LEVELS AND. THE LEVELS OF CONTAMINATION OBSERVED DURING ROUTINE SURVEYS PERFORMED AT THE FACILITY IN TERMS OF THE AVERAGE AND THE HIGHEST LEVELS

E. THE LOCATION AND MAGNITUDE OF THE MAXIMUM MEASURED OR CALCULATED DIRECT RADIATION LEVEL IN UNRESTRICTED AREAS DUE TO DIRECT RADIATION FROH THE FACILITY, AND DIRECT RADIATION FROM FACILITY EFFLUENTS . . . . . V-5

1. The Maximum Direct Radiation Level in Unrestricted Areas Due to Direct Radiation From the Facility............. V -5

2. The Maximum Direct Radiation Level in Unrestricted Areas Due to Direct Radiation From Facility Effluents

F. AN ANNUAL SUMMARY OF. THE GENERAL METHODS AHD THE RESULTS OF ENVIRONMENTAL SURVEYS PERFORMED OUTSIDE THE FACILITY

1. The Onsite Environmental Honitoring systems . . V-16

2. The Offsite Environmental Monitoring Systems . . V-21 


\section{LIST OF TABLES}

TABLE

TITLE

$\underline{P A G E}$

Table III-1 Three Year OSTR Statistics (using FLIP core). III-2

Table III-2 OSTR Statistics with 20\% Enriched Core . . . III-4

Table III-3 Present OSTR Operation Statistics . . . . III-6

Table III-4A OSTR Use Time .............. III-7

Table III-4B OSTR Use Time . . . . . . . . . . . III-7

Table III-5 OSTR Multiple Use Time . . . . . . . . III-8

Table III-6 Experiment Usage Vs. Project . . . . . . III-11

Table III-7 Unplanned Scrams . . . . . . . . III-12

Table III-8 Monthly Tests \& Inspections . . . . . . . III-18

Table III-9 Quarterly Tests \& Inspections . . . . . . III-19

Table III-10 Semi-Annual Tests \& Inspections...... III-20

Table III-11 Annual Tests \& Inspections ........ III-21

Table IV-TA OSTR Teaching Hours............ IV-3

Table IV-IB OSTR Operator Training Hours ....... IV-3

Table IV-2 Statistics of Students in Nuclear Engineering and Nuclear Science Courses... . . . . IV-4

Table IV-3 Other Educational Institutions Using OSTR . . IV-6

Table IV-4 Graduate Students Doing Thesis Research that Used the OSTR............ IV-7

Table IV-5 OSTR Research Hours........... IV-9

Table IV-6 Summary of Oregon State University TRIGA

Research Projects and Funding Agencies... IV-10

Table IV-7 Radiation Center Scheduled Visitors, July 1, 1978 - June 30,1979 . . . . . IV-18 
Table V-1

Monthly Summary of Liquid Waste Discharges for the Year July 1, 1978 through June 30, 1979 .............. . . V-35

Table V-2 Monthly Summary of Gaseous Waste Discharges for the Year July 1, 1978 through June 30, 1979 ................ V-36

Table V-3 Annual Summary of Solid Waste Discharges for the Year July 1., 1978 through June 30, 1979 . V-37

Table V-4 Annual Summary of Radiation Exposure Received by Facility Personnel and Visitors for the Year July 1, 1978 through June $30,1979$. . V-38

Table V-5 Annual Summary of Radiation Levels and Contamination Levels Observed During Routine Radiation Surveys for the Year July 1, 1978 through June 30, 1979 ......... . V-39

Table V-6 Total Dose Equivalent Recorded on OperatingArea Film Badge Monitors Located Inside the TRIGA Reactor Facility for the Year July 1,

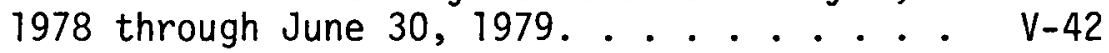

Table V-7 Total Dose Equivalent at the TRIGA Reactor Area Fence for the Year July 1, 1978

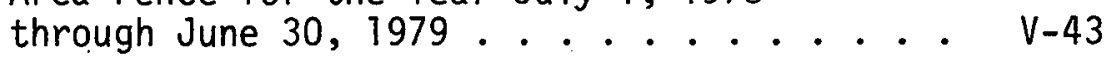

Table V-8 Annual Average Concentrations of Gross Beta Radioactivity for Offsite Environmental Soil, Water, and Vegetation Samples for the Year July 7,1978 through June 30,1979 . . . . V-45

Table V-9 Annual Totals for Offsite Airborne Gamma Monitoring Stations for the Year July 1 , 1978 through June 30, 1979 


\section{LIST OF FIGURES}

Fig. III-1 OSTR Annual Energy Production Vs. Time (Fiscal Year)............ III-3

Fig. III-2 Symmetrical Care Before June 1979... . $\quad$ III-14

Fig. III-3 . Assymetrical Care, June 1979 ...... III-15

Fig. $V-1 \quad$ Operating-Area Film Badge Monitor Locations of the TRIGA Reactor ......... V-40

Fig. V-2 Area Radiation Monitor Locations for the TRIGA and AGN Reactors, and the TRIGA Reactor Area Fence . . . . . . . . . V-41

Fig. V-3 Monitoring Stations for the OSU TRIGA Reactor, January 6, 1976 through June 30, 1979 
I. Introduction and Summary 


\section{INTRODUCTION AND SUMMARY}

A. INTRODUCTION TO OREGON STATE TRIGA REACTOR ANNUAL REPORT

1. This year's annual report will use the format that was introduced in the 1976-77 report.

2. The reporting period will be for one year: 1 July 78 to 30 June 79.

3. All of the information included in this annual report may not be of interest to al1 recipients and will require selected perusal. A comprehensive Table of Contents has been included to aid in such a selection.

4. This year's report will not attempt to review in detail the past operating years for the original $20 \%$ enriched core. A table showing the important operational data for this period (1967-1976) is included as Table III-2, however. This year's report will review the operating history of the $70 \%$ enriched FLIP core (1976-present). The 70\% enriched FLIP core is established as the historical base for subsequent reports.

5. The 1976-77 report. is a good source of detailed information for readers interested in the OSTR's 20\% enriched core history.

B. SUMMARY OF OSTR USE DURING REPORTING PERIOD

During the year July 1, 1978 to June 30, 1979 the Oregon State TRIGA Reactor:

1. Generated 10.6 MWD of energy.

2. Consumed 13.3 grams of ${ }^{235} \mathrm{U}$. 
3. Pulsed 130 times.

4. Two fuel elements were added to the core during the reporting period.

5. Accommodated 10 courses in nuclear engineering and nuclear engineering technology; six courses in nuclear chemistry; and provided demonstrations for classes in lower division chemistry and general science. Also, 29 hours of reactor time was used to furnish special training in reactor operation for four Taiwan Power Company students. (Reactor use time for teaching and instruction totaled 202 hours.)

6. Two reactor operators are starting their training and preparing for reactor operator 1 icensing. These trainees are from Malaysia* participating in a special research reactor operator training program. A total of three hours of reactor time has been used in the training during this reporting period.

7. Accommodated 52 research projects. (Reactor use time for research programs totaled 363 hours.)

8. During a typical week, operated about 22 hours/week.

9. Accommodated 1,095 scheduled visitors and several hundred unscheduled visitors during university open house events. (Reactor use time for visitor demonstration totaled 31 hours.)

10. Reactor use time averaged $55 \%$, based on a 40 -hour week (eight hours a day, five days a week). 
C. SUMMARY OF OSTR ENVIRONMENTAL AND RADIATION PROTECTION DATA

Year July 1, 1978

Through June 30,1979

1. Liquid Waste Data (See Table V-1):

a. Total estimated quantity

of radioactivity released

(in curies)*

$2.30 \times 10^{-5}$

b. Detectable radionuclides

in liquid waste

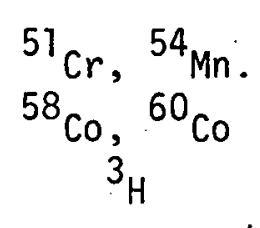

c. Estimated average

concentration of released

radioactive material at

the point of release (in

microcuries per cubic

centimeter)

$2.32 \times 10^{-6}$

d. Percent of applicable MPC

for released 1 iquid

radioactive material at

the point of release (\%)

0.174

e. Total volume of liquid

effluent released,

including diluent, (in

gallons)**

2620

*The OSU operational policy is to subtract only detector background from our water analysis data and not background radioactivity in Corvallis city water.

**Total volume of effluent plus diluent does not take into consideration the additional mixing with approximately 95,000 to 115,000 gallons per year of 1 iquids and sewage normally discharged by the Radiation Center complex into the same sanitary sewer system. 
Year July 1, 1978

Through June 30, 1979

2. Gaseous Waste Data (See Table V-2):

a. Total estimated quantity

of radioactivity released

(in curies)

b. Detectable radionuclides

in gaseous waste*

10.62

${ }^{41} \mathrm{Ar}$
$\left(t_{\frac{1}{2}}=1.83 \mathrm{hr}\right)$

c. Estimated average

atmospheric diluted

concentration of

Argon-41 at the point

of release (in micro-

curies per cubic

centimeter)

$5.97 \times 10^{-8}$

d. Percent of applicable MPC

for diluted concentration

of Argon-4l at the point

of release (\%)

e. Total estimated release of radioactivity in particulate

form with half-lives greater

than 8 days (in curies)**

NONE

3. Solid Waste (See Table V-3):

a. Total amount of solid waste packaged and disposed of (in cubic feet)

b. Detectable radionuclides in solid waste

$$
\begin{aligned}
& { }^{60} \mathrm{Co},{ }^{59} \mathrm{Fe},{ }^{24} \mathrm{Na}, \\
& { }^{56} \mathrm{Mn},{ }^{57} \mathrm{Cr},{ }^{75} \mathrm{Se}
\end{aligned}
$$

c. Total radioactivity in solid waste (in curies)

$6.51 \times 10^{-4}$

* Routine gamma spectroscopy evaluation of the gaseous radioactivity in the stack discharge indicated that it was virtually all Argon-4l.

**Evaluation of the particulate radioactivity in the stack discharge confirmed its origin as naturally occurring radon daughter products, predominantly lead-214 and bismuth-214, not associated.with reactor operations: 
Year Ju1y 1,1978

Through June 30, 1979.

4. Radiation Exposure Received by

Facility Personnel and Visitors

(in mRem)(See Table V-4):

a. Facility operating personnel (mRem)

(1) Average whole body

(2) Average extremities

(3) Maximum whole body

8.00

(4) Maximum extremities

208.00

30.00

680.00

b. Facility research personnel

(mRem)

(1) Average whole body

0.00

(2) Average extremities

82.00

(3) Maximum whole body

0.00

(4) Maximum extremities

450.00

c. Visitors (mRem)

(1) Average whole body

1.00

(2) Maximum whole body

25.00

5. Number of Area and Offsite Environmental

Monitoring Samples Evaluated:

a. Area film badges inside

the TRIGA facility

b. Vendor supplied TLD monitors

on the reactor facility fence

36

c. OSU TLU monitors on the

reactor facility fence

108

d. Integrating ionization chambers

on the reactor facility fence

468

e. $\mu R / h r$ measurements around the perimeter of the reactor facility fence

234

f. Offsite environmental soil samples

g. Offsite environmental

water samples

h. Ofisite environmental

vegetation samples 
Year July 1, 1978

Through June 30,1979

i. Offsite vendor supplied TLD monitors

44

j. Offsite OSU TLD monitors 228

k. Offsite integrating ionization chambers

1. $\mu R / h r$ measurements at the offsite airborne gamma monitoring stations 
II. General Information 


\section{GENERAL INFORMATION}

A. RADIATION CENTER

The Oregon State TRIGA Reactor (OSTR) is housed in the Radiation Center at Oregon State University. The Radiation Center was designed and established to: (1) accommodate internal and off-campus instructional programs; (2) support research and development programs involving nuclear science and engineering; (3) provide a place for the use of radioisotopes and ionizing radiation; and (4) provide fast and thermal neutrons for applicable programs. Construction of the Radiation Center was divided into two phases. The first phase was completed in June 1964 and consisted of 32,397 square feet of office and laboratory space. The second phase was completed in March 1967, and consisted of a nuclear research reactor housed in a 9,956 square foot building adjacent to the existing Radiation Center. In 1975, temporary space of 1,600 square feet was added for interim accommodation of the fast expanding nuclear engineering program. In 1977, additional temporary space of 1,600 square feet was added. The Radiation Center complex at present totals 45,553 square feet.

Housed in the Center are various types of laboratories and equipment designed to furnish:

1. Instruction programs in nuclear engineering, radiation biology, and nuclear and radiation chemistry.

2. Instrumental and radiochemical neutron activation analysis. 
3. Neutron radiography and neutron diffraction.

4. Irradiation experiments involving $x$-ray, gamma-ray, or neutrons.

5. Measurement of various types of ionizing radiation.

6. Consultation in the application of radioisotopes and radiation research.

7. Exploratory programs on the novel uses of radioisotopes and radiation.

B. FACULTY MEMBERS HOUSED AT THE RADIATION CENTER

* Warig, Chih H. (Professor) Director, OSU Radiation Center Reactor Administrator Head, Department of Nuclear Engineering

*Bennett, Casey W. (Instructor) Chemistry (nuclear chemistry)

*Binney, Stephen.E. (Associate Professor)

Nuclear Engineering (nuclear instrumentation)

Daniels, Malcolm (Professor)

Chemistry (radiation chemistry)

*Dodd, Brian (Assistant Professor) Nuclear Engineering (health physics) Health Physicist, OSU Radiation Center

Fairchild, Clifford E. (Professor) Physics (radiation chemistry)

* Hornyik, Kar1 (Associate Professor) Nuclear Engineering (safety analysis and reactor kinetics) Jansen, George. (Visiting Professor) Nuclear Engineering (nuclear fuel cycle)

* Johnson, Arthur F. (Associate Profcssor) Nuclear Engineering (health physics)

Senior Health Physicist, OSU Radiation Center

Kimeldorf, Donald J. (Professor) General Science (radiation biology)

* Reactor users for research and/or teaching. 




1. Post-Doctorate Research Associates

$\begin{array}{lll}\text { Name } & \text { Field } & \frac{\text { Advisur }}{\text { Bahl, Mahinder K. }} \\ \text { Gimzewski, James } & \text { Chemistry } & \text { T.D. Thomas } \\ \text { *Ma, Maw-Suen } & \text { Chemistry } & \text { T.D. Thomas } \\ \text { Chemistry } & \text { R.A. Schmitt }\end{array}$

2. Graduate Students

\begin{tabular}{|c|c|c|c|}
\hline Name & Degree & Field & Advisor \\
\hline $\begin{array}{l}\text { Ades, Maurice } \\
\text { Bomben, Ken }\end{array}$ & $\begin{array}{l}\text { PhD } \\
\text { PhD }\end{array}$ & $\begin{array}{l}\text { Nuclear Engr } \\
\text { Chemistry }\end{array}$ & $\begin{array}{l}\text { K.L. Peddicord } \\
\text { T.D. Thomas }\end{array}$ \\
\hline
\end{tabular}

*Reactor users for research and/or thesis work. 
Graduate Students (continued)

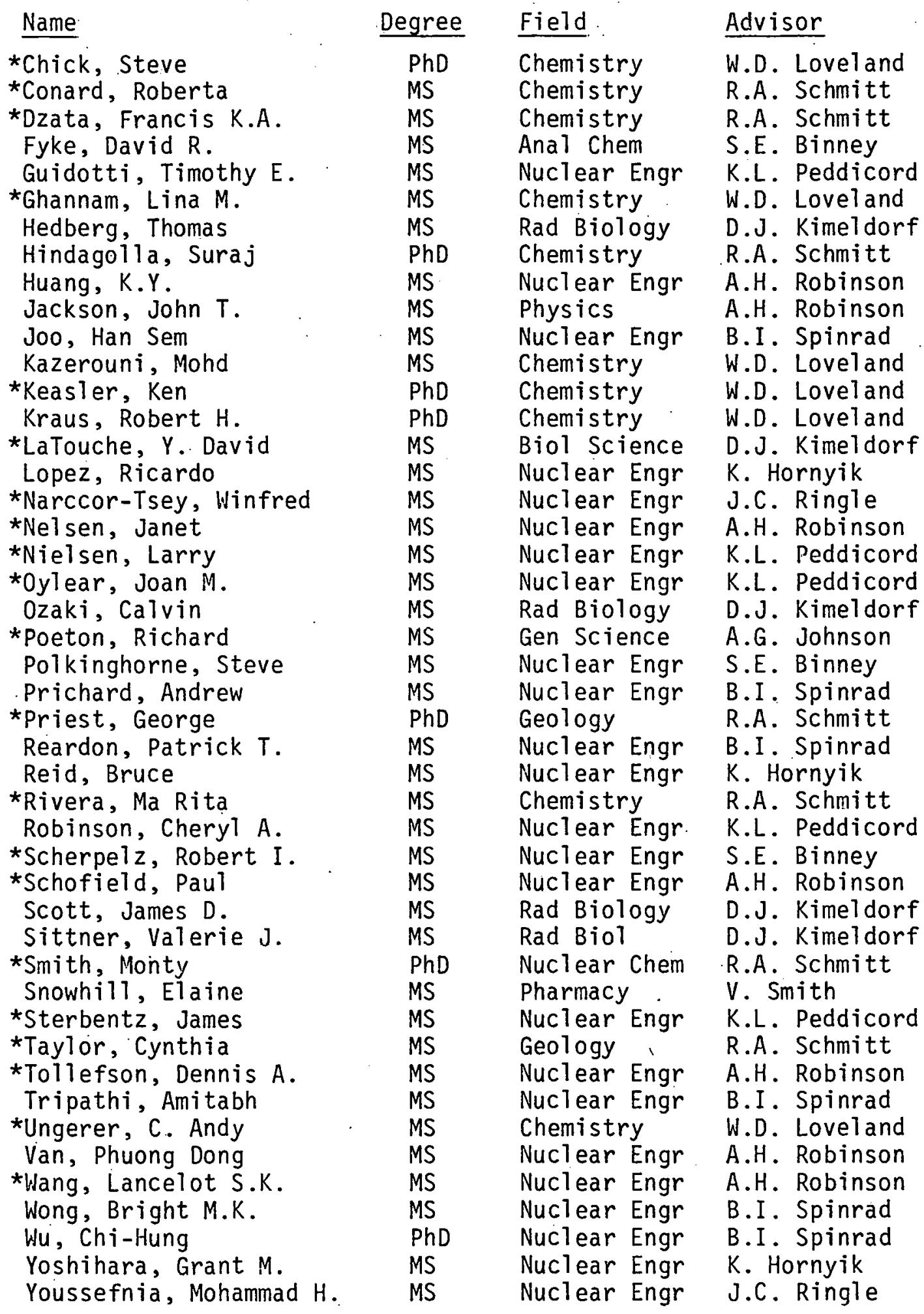

* Reactor users for research and/or thes is work. 
3. Visiting Scientists and Trainees

\begin{tabular}{lll} 
Name & Field (Affiliation) & Advisor \\
\cline { 2 - 2 } & Reactor Operations (Malaysia) & J.C. Ringle \\
*Ali, Yusof & Reactor Operations (Malaysia) & J.C. Ringle \\
*Barton, John P. & Neutron Radiography (IRT Corp.) & C.H. Wang \\
Besar, Idris & Health Physics (Malaysia) & A.G. Johnson \\
*Fawaris, A.H. & Radioecology (Louisiana St. U.) & W.D. Loveland \\
*Fukuoka, Takaaki & Meteorite Studies (Japan) & R.A. Schmitt \\
*Gooding, James & Geology (Univ. of New Mexico) & R.A. Schmitt \\
*Hamzah, Razali & Reactor Operations (Malaysia) & J.C. Ringle \\
*Kamat, Kasbun & Reactor Operations (Malaysia) & J.C. Ringle \\
*Khair, Nahrul & Reactor Operations (Malaysia) & J.C. Ringle \\
*Knaus, Ronald M. Nuclear Chemistry (Louisiana St) & W.D. Loveland \\
*Laul, J.C. & Neutron Act. Anal. (BNWL) & R.A. Schmitt \\
*Leeman, William & Geology (Rice University) & R.A. Schmitt \\
*Nunnelley, Lewis & Nuclear Chemistry & T.D. Thomas \\
Pilus, A. Rahman & Health Physics (Malaysia) & A.G. Johnson \\
*Yunus, Yaziz & Reactor Operations (Malaysia) & J.C. Ringle
\end{tabular}

D. CLASSIFIED STAFF AT THE RADIATION CENTER

Name

Anderson, Terrance $V$.

Bauman, Mary L.

Bennett, Stephen L.

Busby, Harold

Campbe11, Ken

Carpenter, Will iam T.

Clark, Judith A.

Doak, Sandra

Fl ickinger, Evel yn

Keen, Robin Ann

Moeller, Wanda

Schneider, Mary $K$.

Smith, Vernon $N$.

Woodrow, Doyle

Ungier; Leon
Title

Reactor Supervisor

Clerical Specialist

Radiation Specialist

Scientific Instrument Technician

Custodian

Reactor Operator

Business Manager

Clerical Assistant

Secretary

Administrative Assistant

Clerical Specialist

Clerical Assistant

Chemist

Scientific Instrument Technician

Research Assistant-Unclassified

* Reactor users for research and/or thesis work.

E. REACTOR OPERATIONS STAFF

Title

Reactor Administrator

Assistant Reactor Administrator

Reactor Supervisor
Naine

C.H. Wang

J.C. Ringle

T.V. Anderson 


\section{REACTOR OPERATIONS STAFF (continued) \\ Title \\ Senior Reactor Operators}

Reactor Operators

Senior Health Physicist

Health Physicist

Radiation Specialist

F. REACTOR OPERATIONS COMMITTEE

Name

J.C. Ringle (chairman)

T.V. Anderson

S.E. Binney

A.G. Johnson

G.M. Reistad

A.H. Robinson

R.A. Schmitt

D.L. Willis

G. RADIATION SAFETY COMMITTEE

Name

S.E. Binney (chairman)

A.G. Johnson

John Kelley

J.E. Nixon

C.C. Calligan

S.C. Fang

D.J. Reed

R.C. Worrest
Name

J.C. Ringle

S.E. Binney

T.V. Anderson

J.M. Oylear (student)

W.T. Carpenter

A.G. Johnson

B. Dodd

S.L. Bennett

\section{Affiliation}

Nuclear Engineering

Radiation Center

Nuclear Engineering

Radiation Center

Mechanical Engineering

Nuclear Engineering

Nuclear Chemistry

General Science (Rad. Biol.)

Affiliation

Nuclear Engineering

Radiation Center

Radiation Safety office

Food Science \& Technology

Computer Center

Agricultural Chemistry

Biochemistry-Biophysics

General Science 
III. Operational Data 


\section{OPERATIONAL DATA}

\section{A. REVIEW}

1. The OSTR has operated for more than 12 years.

2. From March 1967 to August 1969, the maximum reactor power level was restricted to $250 \mathrm{k} ! \mathrm{s}$.

3. In August 1969 the reactor was licensed to operate at a maximum reactor power level of $1 \mathrm{MW}$. From then until June 1971 the OSTR could operate at 1 MW for only short periods of time, due to the lack of sufficient cooling capacity.

4. In June 1971 the cooling capacity was upgraded to allow continuous operation at $1 \mathrm{MW}$.

5. In July 1976 the reactor was shut down (for a month) and a new FLIP core (70\% enriched fuel) installed.

6. See Table III-l for a tabular review of the OSTR's three year statistics with the FLIP core.

7. See Figure III-7 for a graphical review of the OSTR'S three year energy production with the FLIP core.

8. See Table III-2 for a summary of the OSTR nine year statistics with a standard (20\% enriched) core.

9. This year's Annual Report will not attempt to review the past 12 years, but will only report and review the FLIP core. It will, however, establish the new $70 \%$ enriched fuel as the historical base for subsequent reports. More detailed information concerning the $20 \%$ enriched standard core can be obtained from the 1976-77 Annual Report dated 31 August 77 . 


\section{Table II I-1}

THREE YEAR OSTR STATISTICS

\begin{tabular}{|c|c|c|c|}
\hline FLIP Core & $\begin{array}{c}1 \text { Aug } 76 \\
\text { to } \\
30 \text { Jun } 77^{\star}\end{array}$ & $\begin{array}{l}\text { 1. Ju1 } 77 \\
\text { to } \\
30 \text { Jun } 78\end{array}$ & $\begin{array}{c}1 \text { Jul } 78 \\
\text { to } \\
30 \text { Jun } 79\end{array}$ \\
\hline $\begin{array}{l}\text { Operating Hours } \\
\text { (critical) }\end{array}$ & 875 & 819 & 458 \\
\hline Megawatt Hours & 451 & 496 & 255 \\
\hline Megawatt Days & 19 & 20.6 & 10.6 \\
\hline Grams $235 \mathrm{U}$ Used & 24 & 25.9 & 13.4 \\
\hline $\begin{array}{l}\text { Hours at Ful1 } \\
\text { Power (1 MW) }\end{array}$ & 401 & 481 & 218 \\
\hline $\begin{array}{l}\text { Number of Fuel } \\
\text { Elements Added } \\
\text { to Core }\end{array}$ & (initial loading) & 0 & 2 \\
\hline $\begin{array}{l}\text { Number of Irrad- } \\
\text { iation Kequests }\end{array}$ & 443 & 375 & 329 \\
\hline
\end{tabular}

*Reactor shutdown July 26, 1976 for one month for refueling reactor with new full FLIP core. 
Figure [II-]

OSTR ANNUAL ENERGY PRODUCTION VS. TIME (FISCAL YEAR)

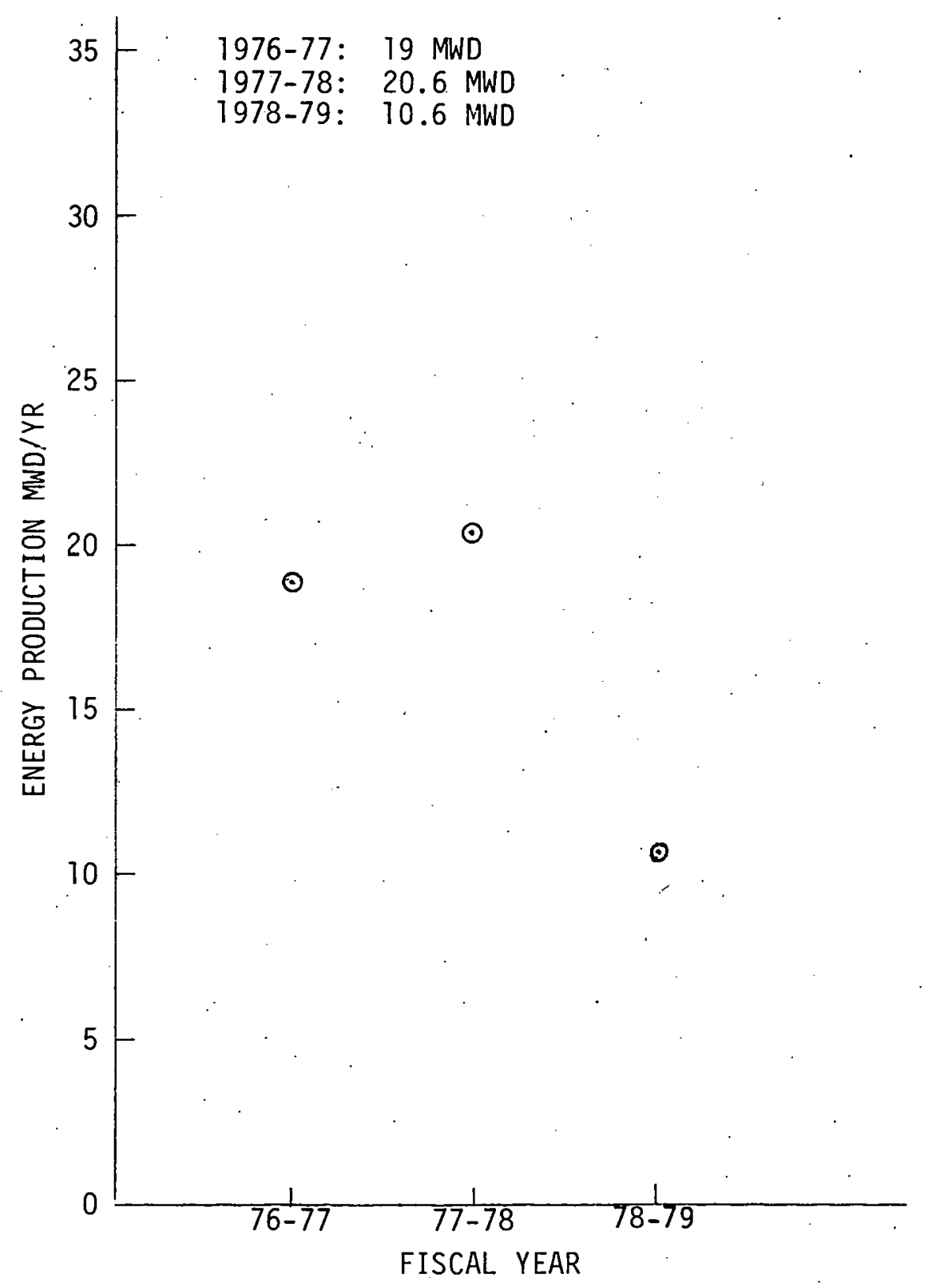


Table $111-2$

OSTR STATISTICS WITH 20\% ENRICHED CORE

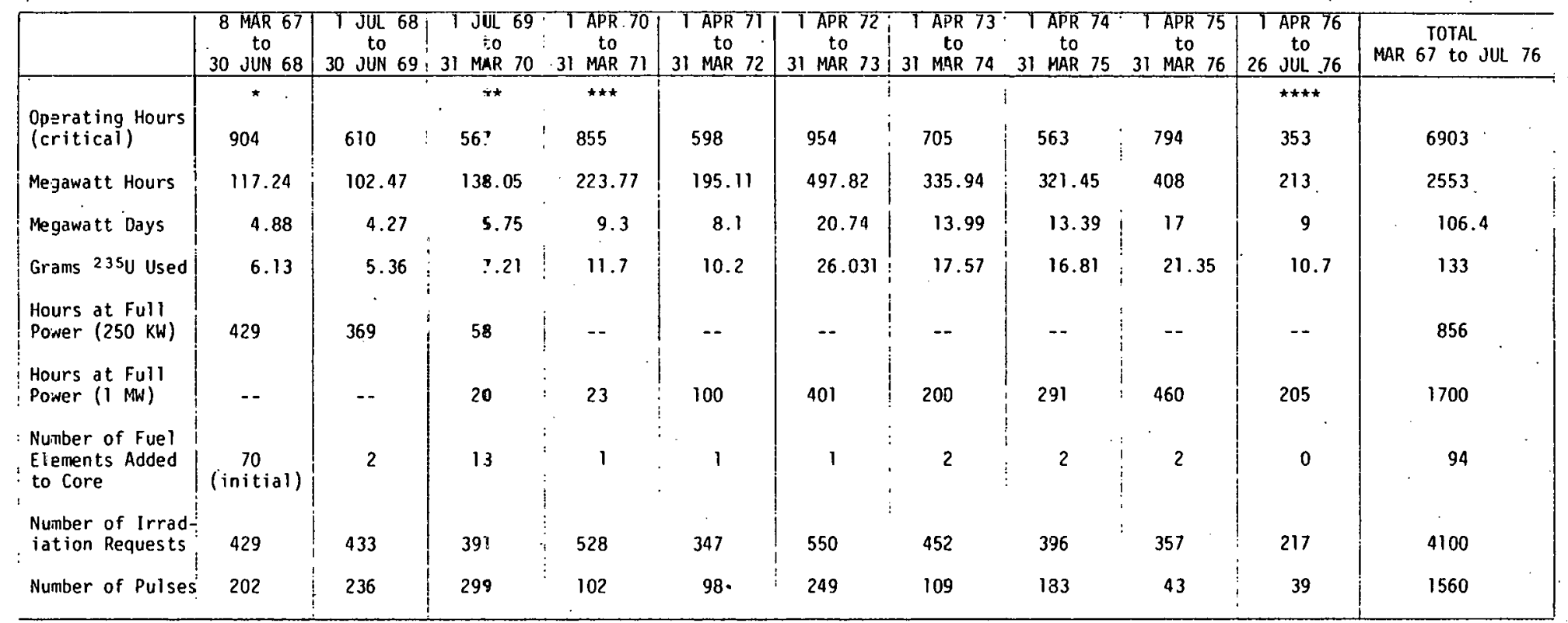

* Reactor became critical on March 8, 1967 (?0 element core; 250 KW). Hote: This period.length is 1.33 years as initial critical

occurred out of phase with the reporting period.

**Reactor shutdown August 22, 1969 for one month for upgrading to 1 MW (did not upgrade cooling system). No:e: This period length is only .75 years as there was a change in the reporting period

***Reactor shutdown June 1, 1971 for one month for cooling system upgrading.

$\star \star \star \star$ Reactor shutdown July 26,1976 for one month for refueling reactor with new full FLIP core. Note: This period length is .33 years. 


\section{B. OPERATING STATISTICS}

The utilization of the OSTR for the reporting period declined to some extent compared to that of the previous year (see Table III-1).

The thermal energy generated in the reactor during the reporting period was 10.64 MWD. (The cumulative thermal energy generated by the FLIP core now totals 50.2 MWD for Aug. 1, 1976 to June 30, 1979). See Tables III-I and III-3 through III-5 for this reporting period's statistics. Reactor use time averaged $255 \%$ of our 8 -hour day, 5 -day week schedule.

Our present rate of excess reactivity decrease with the FLIP core is about $3 \$ /$ MWD. Our present core excess (after the addition of two FLIP fuel elements) is approximately $\$ 6.70$. The initial FLIP core excess was $\$ 7.17$. So far the reactivity loss per MWD with the FLIP core is about the same as with the $20 \%$ fuel. The fuel manufacturer (General Atomic) reports that with the FLIP fuel we should initialiy expect a decrease in reactivity and then eventually (at about 120 MWD) see a. net gain in reactivity. This net gain should peak in about $4.5 \mathrm{MW}$ years and is a result of the burnable poison in the fuel. 
Table III-3

PRESENT OSTR OPERATION STATISTICS

\begin{tabular}{|c|c|c|}
\hline Reactor Operations & $\begin{array}{c}1 \text { July } 78 \\
\text { to } \\
30 \text { Jun } 79\end{array}$ & $\begin{array}{c}\text { FLIP } \\
\text { Cumulative } \\
1 \text { Aug } 76 \\
\text { to date. }\end{array}$ \\
\hline 1. MWH of energy produced & 255 & 1202 \\
\hline 2. MWD of energy produced & 10.6 & 50.2 \\
\hline 3. Grams $235 \mathrm{U}$ used & 13.4 & 63.3 \\
\hline $\begin{array}{l}\text { 4. Number of fuel elements } \\
\text { added to core }\end{array}$ & 2 & $84+3$ FFCR** \\
\hline 5. Number of pulses & 130 & 316 \\
\hline 6. Hours reactor critical & 458 & 2152 \\
\hline 7. Hours at full power (1 MW) & 218 & 1100 \\
\hline $\begin{array}{l}\text { 8. Number of startup } \\
\text { and shutdown checks }\end{array}$ & 246 & 725 \\
\hline $\begin{array}{l}\text { 9. Number of irradiation } \\
\text { requests processed* }\end{array}$ & 329 & 1147 \\
\hline 10. Number of samples irradiated & 4526 & 16,300 \\
\hline
\end{tabular}

*Each request authorized from 1 to 120 samples to be irradiated (the number of samples per irradiation request averaged about 14)

**Fuel Follower Control Rod 
Table III-4A

OSTR USE TIME

\begin{tabular}{|c|c|c|}
\hline $\begin{array}{c}\text { Overall Reactor } \\
\text { Operation Time } \\
\text { Statistics }\end{array}$ & $\begin{array}{c}1 \text { Juty } 78 \\
\text { to } \\
30 \text { Jun } 79 \\
\text { (hours) }\end{array}$ & $\begin{array}{l}\text { FLIP } \\
\text { Cumulative } \\
7 \text { Aug } 76 \\
\text { to date } \\
\text { (hours) }\end{array}$ \\
\hline $\begin{array}{l}\text { 1. Checkout, core excess } \\
\text { and shutdown }\end{array}$ & 358 & 1033 \\
\hline 2. Load and unload samples & 97 & 306 \\
\hline 3. Reactor in operation* & 699 & 2657 \\
\hline 4. Total reactor use time & 1148 & 3996 \\
\hline
\end{tabular}

*Includes preclude time. (Preclude is the time the reactor is not available for use due to inspections and maintenance, such as fuel element inspections; transient rod lubrication, control rod calibration, power calibration, etc.)

Table III-4B

OSTR USE TIME

\begin{tabular}{|c|c|c|c|}
\hline & $\begin{array}{c}\text { Teaching, Research, } \\
\text { Inspection and } \\
\text { Demonstration Time } \\
\text { Statistics }\end{array}$ & $\begin{array}{l}1 \text { July } 78 \\
\text { to } \\
30 \text { Jun } 79 \\
\text { (hours) }\end{array}$ & $\begin{array}{l}\text { FLIP } \\
\text { Cumulative } \\
1 \text { Aug } 76 \\
\text { to date } \\
\text { (hours) }\end{array}$ \\
\hline & $\begin{array}{l}\text { Training (departmental) } \\
\text { and others) } 1,2\end{array}$ & 202 & 627 \\
\hline & OSU research $h^{1,3}$ & 289 & 1374 \\
\hline 3. & Off-campus research ${ }^{1,3}$ & 74 & 257 \\
\hline 4. & Reactor preclude time & 552 & 1666 \\
\hline 5 . & Visitor demonstration & 31 & 72 \\
\hline & Total reactor use time & 1748 & 3996 \\
\hline
\end{tabular}

I Includes sample loading and unloading.

${ }^{2}$ See Tables IV-1 and IV-2 for teaching statistics.

${ }^{3}$ See Table IV-5 for research statistics. 
Table III-5

OSTR MULTIPLE ${ }^{I}$ USE TIME

\begin{tabular}{|l|c|c|}
\hline Number of Users & $\begin{array}{c}1 \text { Jul } 78 \\
\text { to } \\
30 \text { Jun } 79 \\
\text { (hours) }\end{array}$ & $\begin{array}{c}\text { FLIP } \\
\text { Cumulative } \\
\text { 1 Aug 76 } \\
\text { to date } \\
\text { (hours) }\end{array}$ \\
\hline 1. Two users & 37 & 220 \\
2. Three users & 10 & 49 \\
3. Four users & 0.2 & 1.7 \\
$\begin{array}{c}\text { 4. Total multiple } \\
\text { use time }\end{array}$ & $47.2^{2}$ & $270.7^{3}$ \\
\hline
\end{tabular}

1Multiple use time is that time when more than one experimenter had samples in the reactor during critical operations .

${ }^{2} 10 \%$ of total hours the reactor was critical this year.

$312 \%$ of total hours the reactor was critical since startup with FLIP fuel August 1976. 


\section{EXPERIMENTS PERFORMED}

There are at the present time 12 approved experiments on the active list that can be utilized in reactor-related programs. These experiments are 1 isted below:

NOTE: Missing numbers identify those experiments that are in the inactive file and are not being used.

A-1 Reactor operation in any of its modes with no sample irradiation.

B-3 Irradiation of materials in assorted matrices for el ements $\mathrm{H}$ to $\mathrm{Bi}$ inclusive plus natural $T h$ and $U$ for neutron activation analysis.

B-8 Isotope production for elements 1 thru 83 ( $H$ to $B i$ ) excluding $\mathrm{Cd}$.

B-11 Nuclear reaction studies by irradiating stable elements to produce any nuclide formed during the neutron irradiation of natural uranium.

B-12 Exploratory experiments to investigate the TRIGA capability to achieve certain experimental goals. If the TRIGA can achieve the desired goals, a regular experiment is drafted.

B-21 Advanced Neutron Radiography using beam port \#3. (Radiography of all conventional items plus ordinance materials.)

B-23 Measure $\gamma$ decay via $\gamma$ detector in thermal column for nuclear englneerting labs.

B-24 General neutron radiography using beam port \#1. (Ordinance items excluded from radiography in this experiment.)

B-25 Neutron flux monitors to be used to measure relative fluxes at various locations in the reactor core and other irradiation facilities. (Fission probes and self-powered neutron detectors.)

B-29 Reactivity measurements for fuel worth.

B-30 Irradiation of jet, diesel, and furnace fuels. Irradiation of various fuel oils for NAA required a new experiment to satisfy the needs of various cnvironmental agencies . 
B-31 TRIGA flux mapping using all irradiation facilities and foils for determining neutron fluxes.

There are 25 experiments in the inactive file that would require re-approval of the Reactor Operations Committee before using.

of the 12 approved experiments, 10 were used during the reporting period.

See Table III- 6 for a tabulation of the experiments performed during the reporting period. (This table shows the experiments used, how often each was used, and in which particular area the use occurred.) 
Table III-6*

EXPERIMENT USAGE VS. PROJECT

\begin{tabular}{|c|c|c|c|c|c|c|}
\hline Experiment & Research & $\begin{array}{c}\text { Research } \\
\text { Thesis }\end{array}$ & $\begin{array}{c}\text { Lab } \\
\text { Classes }\end{array}$ & Forensic & $\begin{array}{l}\text { Special } \\
\text { Projects }\end{array}$ & Total \\
\hline$A-1$ & -- & -- & 43 & -- & 17 & 60 \\
\hline$B-3$ & 148 & 15 & 42 & 10 & 1 & 276 \\
\hline$B-8$ & 4 & 1 & 25 & -- & 6 & 36 \\
\hline$B-21$ & 28 & 3 & -- & -- & -- & 31 \\
\hline$B-23$ & -- & -- & 7 & -- & -- & 7 \\
\hline$B-24$ & 4 & -- & -- & -- & -- & 4 \\
\hline$B-25$ & -- & -- & 4 & -- & - & 4 \\
\hline$B-29$ & -- & -- & 3 & $\therefore$ & -- & 3 \\
\hline$B-30$ & -- & -- & 2 & - & -- & 2 \\
\hline B-31 & -- & 1 & -- & -- & - & 1 \\
\hline TOTAL & 184 & 20 & 126 & 10 & 24 & 364 \\
\hline
\end{tabular}

*Table displays the number of times a specific experiment was used in a particular area. 
D. UNPLANNED SHUTDOWNS

There was a total of three unplanned shutdowns that occurred during the reporting period. See Table III-7 for tabulation.

Table III-7

UNPLANNED SCRAMS

\begin{tabular}{|l|c|l|}
\hline Type Scram & 0ccurrences & \multicolumn{1}{|c|}{ Cause } \\
\hline Linear Scram & 2 & $\begin{array}{l}\text { Reactor power range switch turned the } \\
\text { wrong way--usualiy by students--during } \\
\text { power increases. }\end{array}$ \\
$\begin{array}{l}\text { External } \\
\text { Scram }\end{array}$ & $\begin{array}{l}\text { Beam port \#1 has a series of inter- } \\
\text { locks associated with beam closure } \\
\text { and access to target area. One lead } \\
\text { shutter was not closed far enough to } \\
\text { trip the micro switch when the access } \\
\text { door was starting to roll open caus- } \\
\text { a scram. }\end{array}$ \\
\hline
\end{tabular}

E. CHANGES IN FACILITY

1. 10 CFR 50.59 Changes

There were no 10 CFR 50.59 changes in our facility and no

new experiments added to the approved list during the reporting period:

2. Other Changes

a. In August of 1978, the annunciator panel was moved from its temporary location, on top of the left console side cabinet, to a position in front of and above the operator. This change was made in anticipation of 
adding a future instrument rack to the top of the left side cabinet. The annunciator panel position is an improvement over the old location.

b. In June of 1979 , the core fuel elements were rearranged to favor an increased neutron flux to beam port \#4, and to increase the transient rod worth. The core configuration was changed from a symmetrical to an asymmetrical arrangement. See Figure III-2 for the symmetrical configuration and Figure III-3 for the asymmetrical arrangement. The transient rod worth increased from $\$ 2.25$ to \$2.78. Mechanical and electrical stops are now used to restrict the transient rod worth to $\$ 2.35$, as required by our Technical Specifications.

c. In June of 1979 , a graphite filler plug was removed from beam port \#4. This graphite plug was inserted into the reflector about six years ago to enhance the neutron in the tangential beam port (BP \#3). A water-filled aluminum plug was inscrted into BP H4 to replace the graphite plug in hopes the neutron beam would be increased for the neutron radiography program. The core excess decreased $23 \$$ with this change of plugs .

3. Planned Changes

a. We plan, in the very near future, to upgrade about half of our existing console electronics. A 
Figure III-2

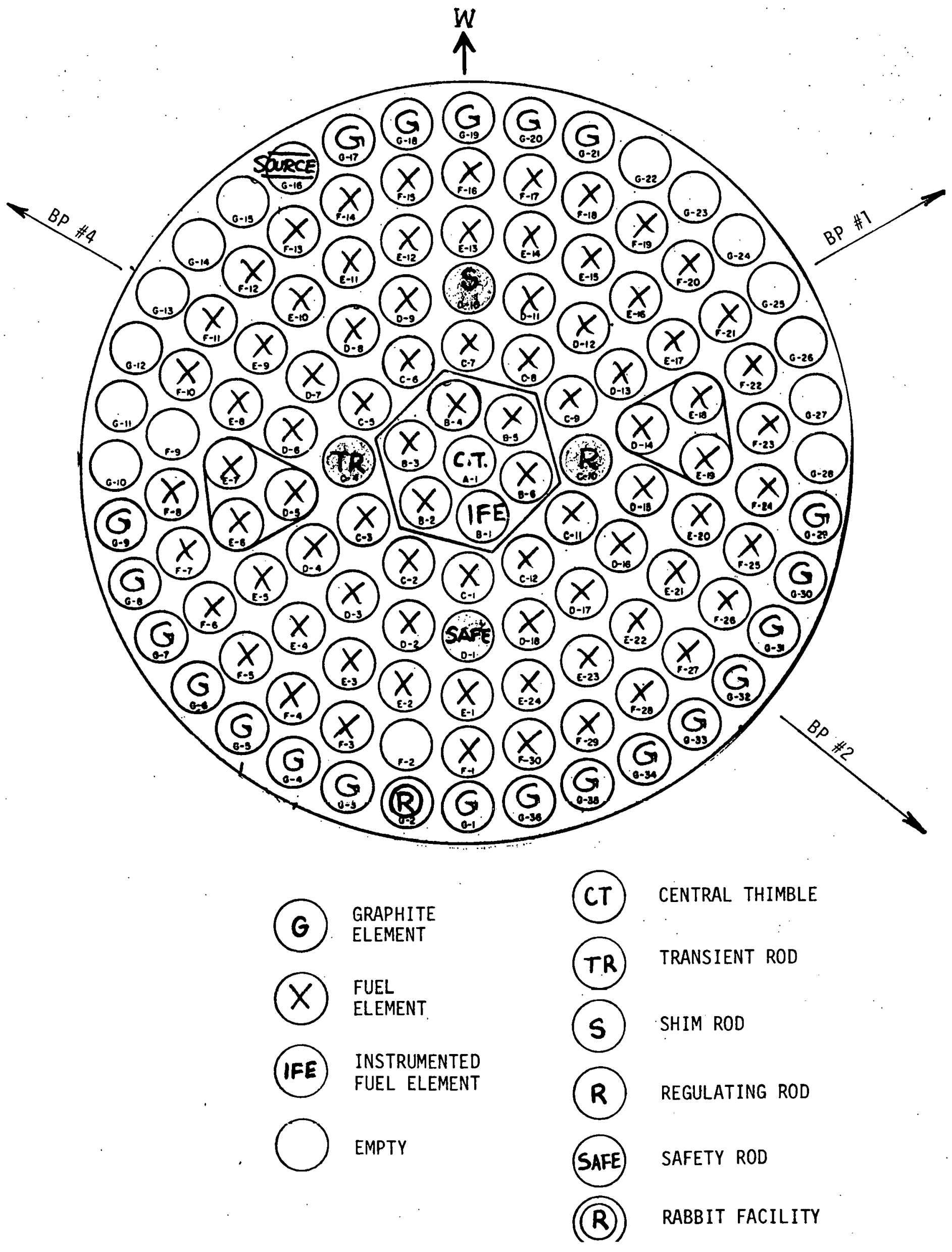


Figure III-3

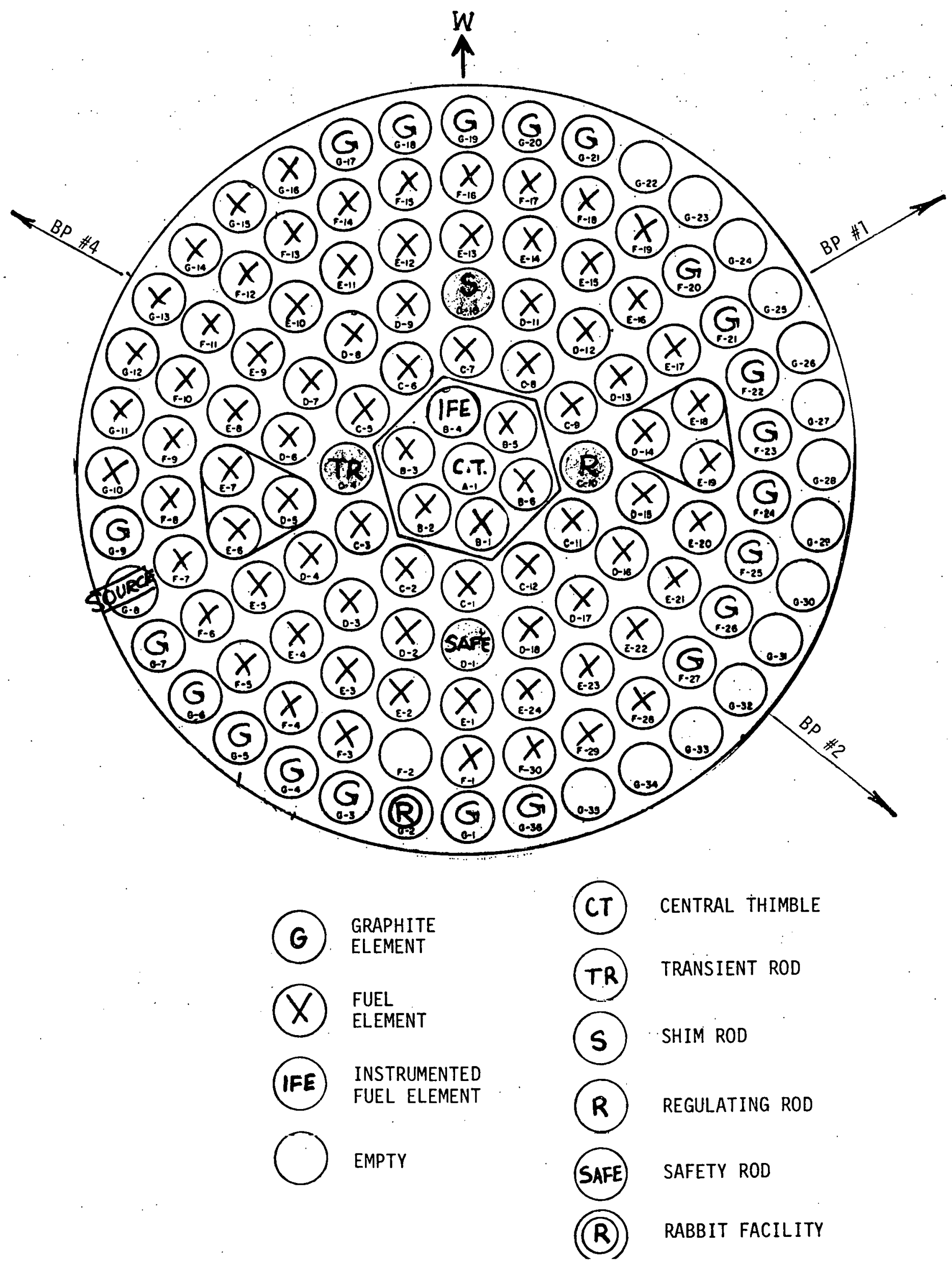


wide-range linear, wide-range $\log$, and safety channel would be added; replacing our present linear, $10 \mathrm{~g}$, and startup channels. We have requested an amendment to our Technical Specifications in a letter dated April 16, 1979 to the NRC to accommodate this electronics upgrading.

b. We are also planning to increase our pulsed reactivity insertion limit from $\$ 2.35$ to $\$ 2.55$. The letter dated April 16, 1979 to the NRC also requests a change in our Technical Specifications to allow this.

c. We plan to add new radiation surveillance equipment to our facility in the form of a new constant air monitor and a new area radiation monitor. This equipment has been ordered, and it should be installed, calibrated, and operational by the end of 1979 .

\section{F. MAINTENANCE AND SURVEILLANCE}

\section{Maintenance}

a. Oct 178: The reactor room exhaust fan motor shorted out. The field windings were replaced and the fan put back in service. The reactor down time was about two days total.

b. Jan 19: The regulating rod drive gear box was replaced. The bull wheel in the gear train was worn out. We had a replacement gear box in our spare parts inventory; thus reactor down time was only about five hours. 
c. Jun 19: The transient rod drive piston ring was replaced. The old ring was deteriorating and letting too much air past the piston resulting in inconsistent reactivity insertion rates and peak power values during pulsing. The ring that was replaced was the original ring installed over 12 years ago. The reactor down time was about 2.5 hours.

2. Tests and Inspections

The OSTR has a routine test and inspection surveillance program. These T\&I lists are presented in Tables III-8 through III-11. Those items marked with an asterisk (*) are required by the Technical Specifications.

\section{G. REPORTABLE OCCURRENCE}

On June 7,1979 , the measured shutdown margin for the OSTR was $\$ 0.48$, nine cents less than our Technical Specifications (Part 3.2) limitation of $\$ 0.57$. This was reported to the NRC, Region V, Office of Inspection and Enforcement by telephone on June 8, 1979 and by a letter dated June 19., 1979.

This incident occurred when the reactor core was changed from a symmetrical arrangement (See Figure III-2) to a asymmetrical arrangement. This change was made to accommodate a neutron radiography research program. 


\begin{tabular}{|c|c|c|c|c|}
\hline & TEST OR INSPECTION TO BE PERFORMED & DUE DATE & $\begin{array}{c}\text { DATE } \\
\text { COMPLETED } \\
\end{array}$ & INITIAL \\
\hline 1. & Functional check of reactor water level alarms. & & & \\
\hline 2. & Measure reactor primary water system $\mathrm{pH}$. & & & \\
\hline 3. & Measure the $\mathrm{pH}$ of the bulk shiled tank water: & & & \\
\hline 4. & Check TRIGA tank water activity. & & & \\
\hline 5. & $\begin{array}{l}\text { Emergency power systems battery liquid level } \\
\text { and terminal checks. }\end{array}$ & & & \\
\hline 6. & $\begin{array}{l}\text { Emergency evacuation alarm system battery } \\
\text { liquid level and terminal checks. }\end{array}$ & & & \\
\hline 7. & Inspect brushes on rabbit system blower motor. & & & \\
\hline 8. & Functional check of evacuation alarm. & & & \\
\hline 9. & Blow down the transient rod air accumulator tank. & & & \\
\hline 10. & $\begin{array}{l}\text { Calculate the average monthly conductivity. } \\
\text { (Average conductivity must be less than } 5 \\
\text { micro mhos per centimeter.) }\end{array}$ & & & \\
\hline 11. & Change the light bulb in the green light. & & & \\
\hline 12. & $\begin{array}{l}\text { Change the light above side entrance to reactor } \\
\text { building. }\end{array}$ & & & \\
\hline 13. & $\begin{array}{l}\text { Check filter tape speed on stack monitor } \\
(1 " / h r) \text {. }\end{array}$ & & & \\
\hline 14. & Lubricate the TRIGA tube loading tool as needed. & & & \\
\hline 15. & Check cam oil level. & & & \\
\hline 16. & Propane tank liquid level check ( $\%$ full) & & & \\
\hline
\end{tabular}


Table III-9

T \& I'S FOR THE QUARTER OF






\begin{tabular}{|c|c|c|c|c|}
\hline & TEST OR INSPECTION TO BE PERFORMED & DUE DATE & $\begin{array}{c}\text { DATE } \\
\text { COMPLETED }\end{array}$ & INITIAL \\
\hline 1. & $\begin{array}{l}\text { Functional check of the following interlocks: } \\
\text { (a) Source interlock. } \\
\text { (b) Simultaneous withdrawal of } 2 \text { rods. } \\
\text { (c) Pulse initiation above } 1 \mathrm{kw} \text {. } \\
\text { (d) Pulse interlock on range switch position } 1 \mathrm{MW} \text {. } \\
\text { (e) Transient rod cylinder air interlock. } \\
\text { (f) Pulse mode rod movement interlock. } \\
\text { (g) Prevents pulsing above } \$ 2.35 \text { reactivity } \\
\text { insertion. }\end{array}$ & & & \\
\hline \pm 2 & $\begin{array}{l}\text { Test safety circuits below: } \\
\text { (a) Linear channel. } \\
\text { (b) Safety channel. } \\
\text { (c) Manual scram. } \\
\text { (d) Preset times on pulse (less than } 15 \text { seconds). }\end{array}$ & & & \\
\hline * 3 & $\begin{array}{l}\text { Check (1) rod drop time (time must be less than } \\
\text { two seconds) and (2) rod withdrawal and insertion } \\
\text { time. } \\
\begin{array}{|l|l|l|l|l|} & \text { TRANS } & \text { SAFE } & \text { SHIM } & \text { REG } \\
\text { Rod Drop } & & & & \\
\text { Withdrawal } & & & & \\
\text { Insertion } & & & & \\
\end{array}\end{array}$ & & & \\
\hline * 4 & $\begin{array}{l}\text { Pulse reactor and compare fuel temperature and } \\
\text { peak power with previous pulses of the same } \\
\text { reactivity insertion. }\end{array}$ & & & \\
\hline$\star 5$ & $\begin{array}{l}\text { Functional check of reactor room ventilation } \\
\text { shutdown system. }\end{array}$ & & & \\
\hline$* 6$ & Calibrate FE temp. meter. & & & \\
\hline$\star 7$ & ROC MTG at least semiannual. & & & \\
\hline$\star 8$. & $\begin{array}{l}\text { Clean and lubricate transient rod internal } \\
\text { barrel and piston (check for excessive air } \\
\text { leakage). }\end{array}$ & & & \\
\hline 9. & $\begin{array}{l}\text { Lube ball nut drive and threaded cylinder on } \\
\text { transient rod. }\end{array}$ & & & \\
\hline 10. & $\begin{array}{l}\text { Lubricate lazy susan drive and indicator assembly } \\
\text { bearings. }\end{array}$ & & & \\
\hline 11. & $\begin{array}{l}\text { MAP-1B: Disassemble and clean orifice plate for } \\
\text { flow indicator. }\end{array}$ & & & \\
\hline 12. & $\begin{array}{l}\text { Console: Perform check 1ist (Appendix I in } \\
\text { GA manual } \# 7615 \text { ). }\end{array}$ & & & \\
\hline :13. & $\frac{\text { AM-2A Air Monitor: Inspect and clean recorder, }}{\text { Iightly lubricate recorder bearings. }}$ & & . & \\
\hline 14. & Westronics Recorder: Check zero and calibration. & & & \\
\hline
\end{tabular}




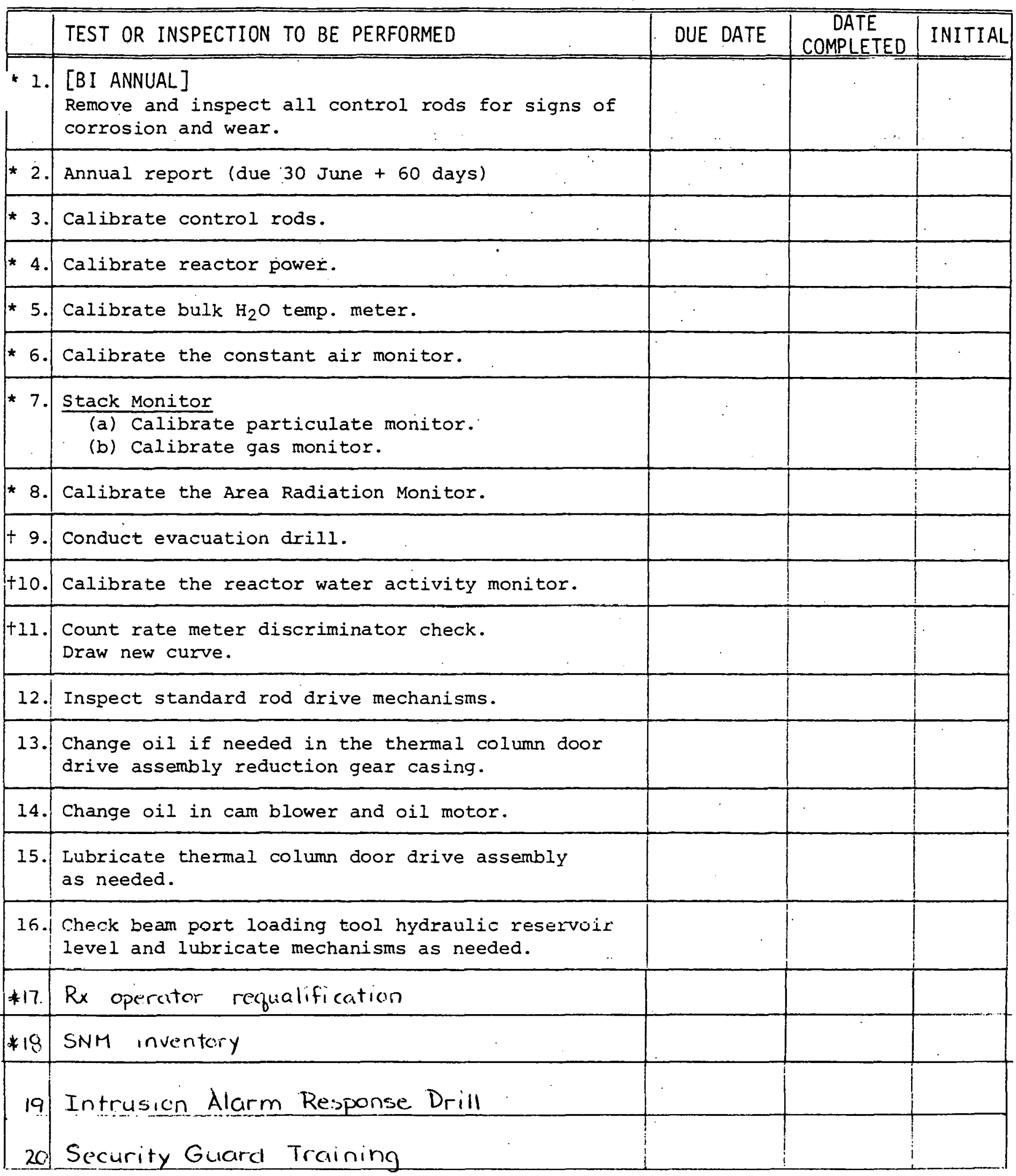


The core change had been reviewed and approved by the Reactor Operations Committee. The change was carried out in sequences, with rod worths being measured and shutdown margins calculated at the end of each sequence. After the final sequence, the core excess reactivity had increased more and the control rod worths had increased less than was predicted from the previous sequence. This resulted in a shutdown margin slightly less than the limit in the Technical Specifications .

As soon as this situation was discovered, two fuel elements were moved and the shutdown margin went up to $\$ 0.74$. See Figure III-3 for the final asymmetrical core arrangement. More details regarding this incident can be found in our letter to NRC dated June 19, 1979. 
IV. Utilization Data 
IV. UTILIZATION DATA

A. TEACHING PROGRAMS

1. The OSTR was used to accommodate 10 courses in nuclear engineering and nuclear engineering technology. These courses were:
NE 101 Nuclear Engineering Orientation
NE 102 Nuclear Engineering Orientation
NE 441 Nuclear Reactor Experiments
NE 442 Nuclear Reactor Experiments
NE 203 Nuclear Radiation Detection and Measurement
NT 203 Nuclear Radiation Detection and Measurement
NT 311 Radiation Protection
NT 312 Radiation Protection
NT 491 Nuclear Technology Experiments
NT 492 Nuclear Technology Experiments

Six chemistry courses utilized the OSTR. They were:
CH 107 General Chemiștry Laboratory
CH 419 Radioactive Tracer Methods
$\mathrm{CH} 528$ Activation Analysis
$\mathrm{CH} 316$ Radiochemistry
CH 207 General Chemistry Laboratory
CH 515 Experimental Nuclear Chemistry

2. A special class was held for four Taiwan Power Company students, which was an introduction to nuclear reactor operations. The training included at least 10 startups and shutdowns for each student, with power changes in manual and automatic modes., rod balancing, temperature effects, scram recovery, and approach to critical. A total of 29 hours of reactor time was required for this class during the reporting period. See Tables IV-1A, IV-2, IV-3, and IV-4 for data showing the use of the OSTR to accommodate teaching and academic programs. 
3. Two trainees from Malaysia arrived September, 1978. They enrolled in several academic classes and started their training for a reactor operator 1 icense in June, 1979. The Malaysian operator training was integrated into the regular reactor schedule and therefore their hours of on-the-job training are not reflected in any of the teaching statistics. (See Table IV-1B.) The Malaysian operators are Yaziz Bin Yunis and Mohd. Puàd Bin Haji Abu. 
Table IV-1A

OSTR TEACHING HOURS

\begin{tabular}{|l|c|c|}
\hline \multicolumn{1}{|c|}{ Description } & $\begin{array}{c}1 \text { Jut } 78 \\
\text { to } \\
30 \text { Jun } 79 \\
\text { (hours) }\end{array}$ & $\begin{array}{c}\text { Cumulative } \\
\text { 1 Aug } 76 \\
\text { to date } \\
\text { (hours) }\end{array}$ \\
\hline $\begin{array}{l}\text { Departmental } \\
\text { Chemistry (58) } \\
\text { Nuclear Engineering (83) } \\
\text { Nuclear Engineering Technology (29) }\end{array}$ & 170 & 567 \\
$\begin{array}{l}\text { Special Classes } \\
\text { Reactor Operator Trainees }\end{array}$ & & \\
Urban League Workshop & & \\
Total Teaching Time 2,3 & $202^{4}$ & 57 \\
\hline
\end{tabular}

${ }^{I}$ Special training class was conducted for four Taiwan Power Company students.

2 Includes sample loading and unloading.

${ }^{3}$ See Table IV-2 for class and student statistics

${ }^{4}$ See Table III-4B.

Table IV-TB

OSTR OPER̈ATOR TRAINING HOURS

\begin{tabular}{|l|c|}
\hline \multicolumn{1}{|c|}{ Name } & Training Accomplishment \\
\hline Yaziz Bin Yunis & Reactor Operator \\
Mohd. Puad Bin Haji Abu & Reactor Operator \\
\hline Total Training Hnurs & 3 \\
\hline
\end{tabular}


Table IV-2

STATISTICS OF STUDENTS IN

NUCLEAR ENGINEERING AND NUCLEAR SCIENCE COURSES

\begin{tabular}{|c|c|c|c|c|c|}
\hline \multirow[b]{2}{*}{ Course } & \multirow[b]{2}{*}{$\mathrm{Cr}$. } & \multirow[b]{2}{*}{ Course Title } & \multicolumn{3}{|c|}{ Number of Students } \\
\hline & & & $\begin{array}{c}\text { FAL } \\
1978\end{array}$ & $\begin{array}{l}\text { WIN } \\
1979 \\
\end{array}$ & $\begin{array}{c}\text { SPR } \\
1979 \\
\end{array}$ \\
\hline \multicolumn{6}{|c|}{ Nuclear Engineering Courses } \\
\hline NE 101* & 3 & Nuclear Engineering Orientation & 17 & -- & -- \\
\hline NE 102* & 3 & Nuclear Engineering Orientation & -- & 18 & -- \\
\hline NE $103 x$ & 3 & Nuclear Engineering Fundamentals & -- & -- & 20 \\
\hline NE 201 & 3 & Nuclear Energy Fundamentals & 28 & -- & -- \\
\hline NE 202 & 3 & Nuclear Radiation \& Matter & -- & 23 & -- \\
\hline $\begin{array}{l}\text { NE } 203^{* *} \\
\text { NF } 406\end{array}$ & 3 & Nuclear Radiation Detection \& Meas. & $-\overline{5}$ & -- & $\begin{array}{r}26 \\
6\end{array}$ \\
\hline $\begin{array}{l}\text { NE } 406 \\
\text { NE } 407\end{array}$ & 1 & $\begin{array}{l}\text { Projects } \\
\text { Seminar }\end{array}$ & -2 & 20 & -- \\
\hline NE 420 & 3 & Intro. to Nuclear Reactor Analysis & -- & -- & 31 \\
\hline NE 421 & 3 & Nuclear Reactor Analysis \& Comput. & 34 & -- & -- \\
\hline NE 422 & 3 & Nuclear Reactor Analysis \& Comput. & -- & 32 & -- \\
\hline NE 423 & 3 & Nuclear Reactor Analysis \& Comput. & -- & -- & 30 \\
\hline NE $447 * *$ & 3 & Nuclear Reactor Experiments & 29 & -- & -- \\
\hline NE $442 * \star$ & 3 & Nuclear Reactor Experiments & -- & 23 & -- \\
\hline NE 461 & 3 & Reactor Thermohydraulics \& Power Gen. & 21 & -- & -- \\
\hline NE 462 & 3 & Reactor Thermohydraulics \& Power Gen. & 31 & -- & -- \\
\hline NE 463 & 3 & Reactor Design & -- & -- & 17 \\
\hline NE 464 & 3 & Reactor Safety Engineering & -- & .25 & -- \\
\hline NE 465 & 3 & Nuclear Fuel Cycle & -- & 38 & -- \\
\hline NE 481 & 3 & Nuclear Materials & -- & -- & 34 \\
\hline NE 501 & & Research & 1 & 1 & 3 \\
\hline NE 503 & $1=15$ & Thes is & 8 & 8 & 9 \\
\hline NE 505 & & Reading \& Conference & 1 & 6 & 12 \\
\hline NE $506 \mathrm{P}$ & & Projects & -- & -- & \\
\hline NE 507 & & Seminar & - & 2 & -- \\
\hline NE 511 & 2 & Neutron Trans. Theory & 7 & -- & -- \\
\hline NE 512 & 2 & Neutron Trans: Theory & & 5 & -- \\
\hline NE 513 & 3 & Nuclear Reactions Var. Thry. & -- & -- & 5 \\
\hline NE 521 & 3 & Reactor Environmental Problems & 6 & -- & -- \\
\hline NE 522 & 3 & Reactor Safety Problems. & -- & 4 & -- \\
\hline NE 523 & 3 & Advanced Reactor Design & -- & -- & 7 \\
\hline NE 531 & 3 & Nuclear Reactor Kinetics & - & 7 & -- \\
\hline NE 535 & 2 & Nuclear Reactor Burnup & 11 & -- & $\therefore$ \\
\hline NE 552 & 3 & Computational Methods for Nuc. React. & - & 17 & -- \\
\hline NE 553 & 3 & Computational Methods for Nuc. React. & -- & - & 10 \\
\hline NE 581 & 3 & Selected Topics in Reactor Theory & -- & 10 & -- \\
\hline
\end{tabular}

*OSTR used occasionally for demonstration experiments.

**OSTR heavily used. 


\begin{tabular}{|c|c|c|c|c|c|}
\hline & & & Numbe & of St & dents \\
\hline Course & $\mathrm{Cr}$. & Course Title & $\begin{array}{c}\text { FAL } \\
1978 \\
\end{array}$ & $\begin{array}{l}\text { WIN } \\
1979 \\
\end{array}$ & $\begin{array}{c}\text { SPR } \\
1979 \\
\end{array}$ \\
\hline Nuclear $E$ & ingint & eexing Technology Courses & & & \\
\hline NT $101 *$ & 3 & Nuclear Engineering Orientation & 5 & - & -- \\
\hline NT $102 x *$ & 2 & Nuclear Engineering Orientation & -- & 3 & -- \\
\hline NT $103 x$ & 3 & Nuclear Engineering Fundamentals & -- & -- & 1 \\
\hline NT 201 & 3 & Nuclear Energy Fundamentals & 5 & -- & - \\
\hline NT 202 & 3 & Nuclear Radiation \& Matter & -- & 4 & -- \\
\hline NT $203 * *$ & 3 & Nuclear Radiation Detection \& Meas. & -- & -- & 4 \\
\hline NT $311 * \star$ & 4 & Radiation Protection & -- & 13 & -- \\
\hline NT $312^{* *}$ & 4 & Radiation Protection & -- & - & 8 \\
\hline NT $330 x$ & 3 & Nuclear Engr. Calculations & -- & -- & 7 \\
\hline NT 405 & 1 & Reading \& Conference & -- & 1 & $\therefore$ \\
\hline NT $405 \mathrm{~A}$ & 1 & Reading \& Conference (Nuclear Engr. Calc.) & 10 & -- & -- \\
\hline NT 406 & & Projects & -- & 1 & 7 \\
\hline NT 407 & & Seminar & 6 & -- & \\
\hline NT 410 & 3 & Field Practice & 2 & -- & $=-$ \\
\hline NT 411 & 3 & Nuclear Rules \& Regulations & 12 & -- & -- \\
\hline NT 413 & 3 & Nucl ear Plant Environmental. Impact & -- & -- & 11 \\
\hline NT 431 & 3 & Nuclear Power Plant Technology & 16 & -- & -- \\
\hline NT 432 & 3 & Nuclear Power Plant Technology & -- & 14 & $=$ \\
\hline NT 433 & 2 & Nuclear Quality Assurance & -- & -- & 13 \\
\hline NT $497 * *$ & 3 & Nuclear Technology Experiments & 9 & -- & -- \\
\hline NT $492 \star * \mid$ & 3 & Nuclear Technology Experiments & -- & 9 & -- \\
\hline Chemistry & Cou & rses & & & \\
\hline CH 105 & 4 & General Chemistry Lecture & -- & 631 & 94 \\
\hline CH 107* & 2 & General Chemistry Labs & 67 & -- & -- \\
\hline $\begin{array}{ll}\mathrm{CH} & 207^{*} \\
\mathrm{CH} & 316^{* *}\end{array}$ & $\begin{array}{l}2 \\
3\end{array}$ & Nuclear Reactor Chemistry & 32 & -- & -- \\
\hline $\mathrm{CH} 419 * \star$ & 4 & Radioactive Tracer Methods & 10 & -- & -- \\
\hline CH $515 * *$ & 3 & Experimental Nuclear Chemistry & -- & -- & 4 \\
\hline $\mathrm{CH} 528 * \star$ & 3 & Activation Analysis & -- & 11 & -- \\
\hline other Cou & urses & & & & \\
\hline GS 460 & 3 & Radiation Health & 13 & -- & -- \\
\hline Special $c$ & 1 ass & for Taiwan Power Company & -- & & 4 \\
\hline
\end{tabular}

*OSTR used occasionally for demonstration experiments.

**OSTR heavily used. 
Table IV-3

OTHER EDUCATIONAL INSTITUTIONS USING OSTR*

\begin{tabular}{|l|c|c|c|}
\hline & $\begin{array}{c}\text { Number of } \\
\text { Facul ty } \\
\text { Involved }\end{array}$ & $\begin{array}{c}\text { Number of } \\
\text { Students } \\
\text { Involved }\end{array}$ & $\begin{array}{c}\text { Number of } \\
\text { Visits to } \\
\text { OSTR }\end{array}$ \\
\hline University of Oregon & $5^{\star *}$ & $7 * *$ & 7 \\
Louisiana State University & 1 & 0 & 1 \\
$\begin{array}{l}\text { Urban League Workshop } \\
\text { (Portland) }\end{array}$ & 1 & 0 & 1 \\
\hline
\end{tabular}

*Does not count community college, high school and grade school classes that come through for special tours. These are listed under the section on "Public Relations."

** Includes researchers and students from other universities working through the University of Oregon. (See Table IV-4.) 


\section{Table IV-4}

GRADUATE STUDENTS DOING THESIS RESEARCH THAT USED THE OSTR

\begin{tabular}{|c|c|c|c|c|}
\hline Name & Degree & Department & Advisor & Thes is \\
\hline \multicolumn{5}{|c|}{ Oregon State University } \\
\hline R. Cobler & MS & Chemistry & Dymond & Galapagos Rise Hydrothermal Study \\
\hline R. Poeton & MS & General Science & Johnson & Effect of Cadmium Ratio on TLD Flux Calibration \\
\hline K. Keasler & PhD & Chemistry. & Lovel and & $\begin{array}{l}\text { Stable Activable Tracer for an Estuarine } \\
\text { Environment }\end{array}$ \\
\hline G. Priest & PhD & Geology & Taylor & Analysis Little Walker Rocks \\
\hline \multicolumn{5}{|c|}{ University of Oregon } \\
\hline S. Goldberg & PhD & Geology & Goles & Anorthosite Genesis \\
\hline C. Bow & PhD & Geology & Goles & Geochemistry of Galapagos Lavas \\
\hline H. Nashland & PhD & Geology & McBirney & $\begin{array}{l}\text { Petrology of the Upper Border Group of the } \\
\text { Skaergaard Intrusion }\end{array}$ \\
\hline C. White & MS & Geology & McBirney & Sodium Analysis of Mt. Hood Geologic Samples \\
\hline
\end{tabular}




\section{B. RESEARCH PROJECTS}

Fifty-two research projects utilized 363 hours of reactor time. Thirty-two of these research projects were from Oregon State University, 19 were from the University of Oregon, and one was from Battelle Northwest in Richland, Washington.

Three of the Oregon State University projects were conducted and correlated with other universities and institutions. These organizations were:

1. Rice University

2. Louisiana State University

3. Battelle Northwest Laboratory*

Several of the University of Oregon projects were also correlated with other universities. These institutions were:

1. MCGill University (Montreal, Canada)

2. University of British Columbia (Canada)

3. Washington State University

4. University of Georgia

5. University of Tubigen (Germany)

6. Universily of Califurmid, Riverside. See Table IV-5 for statistics regarding research hours and Table IV-6 for a summary of the research projects.

*Under ERDA prime contract EY-76-6-06-1830. 
Table IV-5

OSTR RESEARCH HOURS

\begin{tabular}{|c|c|c|}
\hline $\begin{array}{c}\text { Reactor Research } \\
\text { Hours Statistics }\end{array}$ & $\begin{array}{c}1 \text { JuT 78 } \\
\text { to } \\
30 \text { Jun } 79 \\
\text { (hours) }\end{array}$ & $\begin{array}{c}\text { Cumulative } \\
\text { T Aug 76 } \\
\text { to date } \\
\text { (hours) }\end{array}$ \\
\hline $\begin{array}{c}\text { OSU Research* } \\
\text { (About 10\% of this time was } \\
\text { thesis \& research combined) } \\
\text { off-Campus Research* } \\
\text { (About 14\% of this time was } \\
\text { thesis \& research combined) } \\
\text { Commercial }\end{array}$ & 289 & 1374 \\
Total Research* & 74 & 257 \\
\hline
\end{tabular}

*Includes sample loading and unloading time.

NOTE: Research hours, OSU funded: 114

Research hours, other funded: 249 
- Iable_IV-6

SUMMARY CIF OREGON STATE UNIVERSITY TRIGA RESEARCH PROJECTS AND FUNDING AGENCIES

\begin{tabular}{|c|c|c|c|c|c|}
\hline $\begin{array}{l}\text { Listing } \\
\text { Number }\end{array}$ & $\begin{array}{l}\text { Name of Person(s) } \\
\text { Using Reactor }\end{array}$ & $\begin{array}{l}\text { Department and } \\
\text { Institution }\end{array}$ & Project Title & Description & Funding *Agency \\
\hline 1. & $\begin{array}{l}\text { R.A. Schmitt, } \\
\text { I.J. Tinșley }\end{array}$ & $\begin{array}{l}\text { Ag Chemistry, } \\
\text { OSU }\end{array}$ & Toxicology of Brominated Oils & INAA of Bromine in Marine Organisms & NIIHS \\
\hline 2. & $\begin{array}{l}\text { R.A. Schmitt } \\
\text { I.J. Tinsley }\end{array}$ & $\begin{array}{l}\text { Ag Chemistry } \\
\text { OSU }\end{array}$ & Toxicology of Brominated Fatty Acids & $\begin{array}{l}\text { Evaluation of the Distribution and } \\
\text { Absorption of Brominated Fatty Acids }\end{array}$ & NIIHS \\
\hline 3. & $\begin{array}{l}\text { R.A. Schmitt } \\
\text { M. Snith }\end{array}$ & Chemistry, JSU & $\begin{array}{l}\text { Lunar and Meteoritic Activation } \\
\text { Analys is for Thesis (Ph.D.) }\end{array}$ & $\begin{array}{l}\text { Chemical \& Petrological Characteri- } \\
\text { zation of Rock Casts in a Brecclated } \\
\text { Meteorite }\end{array}$ & NASA \\
\hline 4. & $\begin{array}{l}\text { R.A. Schmitt, } \\
\text { M.S. Ma }\end{array}$ & Chemistry, DSU & $\begin{array}{l}\text { Chemical Studies of Lunar, } \\
\text { Meteoritic and Terrestrial Samples }\end{array}$ & INAA of Selected Samples & NASA \\
\hline 5. & $\begin{array}{l}\text { R.A. Schmitt, } \\
\text { W.P. Leeman }\end{array}$ & $\begin{array}{l}\text { Chemistry, oSU } \\
\text { \& Rice Univ }\end{array}$ & $\begin{array}{l}\text { Trace El ement Studies of Volcanic } \\
\text { Rocks }\end{array}$ & $\begin{array}{l}\text { INAA for Selected Trace Elements in } \\
\text { a Variety of Volcanic Rocks From } \\
\text { French and Hawail Polynesia }\end{array}$ & Rice University \\
\hline 6. & $\begin{array}{l}\text { R.A. Schmit:, } \\
\text { G. Priest }\end{array}$ & Geology, OSU & $\begin{array}{l}\text { Composition Analysis of Selected } \\
\text { Volcanic Rocks for Thesis (Ph.D) }\end{array}$ & $\begin{array}{l}\text { INAA for Trace Elements in Little } \\
\text { Walker Volcanic Center }\end{array}$ & OSU Geology Dept. . \\
\hline 7. & $\begin{array}{l}\text { R.A. Schmitt } \\
\text { A. Weibel }\end{array}$ & Chemistry, CSU & Carbonate Crystal INAA & $\begin{array}{l}\text { Crystals Found in Geothermal } \\
\text { Investigattons to be Analyzed } \\
\text { for Uranlum \& Thorium }\end{array}$ & OSU Radiation Center. \\
\hline 8. & $\begin{array}{l}\text { R.A. Schmitt, } \\
\text { A. Weibel }\end{array}$ & Chemistry, asu & INAA of African Soils & $\begin{array}{l}\text { Examine Soils From Kenya, Africa } \\
\text { to Correlate with Published Data }\end{array}$ & OSU Radiation Center \\
\hline 9 . & $\begin{array}{l}\text { R.A. Schmitt, } \\
\text { L. Norris }\end{array}$ & $\begin{array}{l}\text { Forestry Sci. } \\
\text { Lab, OSU }\end{array}$ & Dy Tracer Studies & $\begin{array}{l}\text { INAA for Dy Tracer in Forest } \\
\text { Spraying }\end{array}$ & $\begin{array}{l}\text { OSU } \\
\text { Forestry Science Lab. }\end{array}$ \\
\hline 10. & $\begin{array}{l}\text { R.A. Schmitt, } \\
\text { E. Trione }\end{array}$ & osu & Western Wheat Quality Control & $\begin{array}{l}\text { INAA for Funge Which is Found in } \\
\text { Wheat. To Determine any Difference } \\
\text { in El emental Content. }\end{array}$ & OSU Radiation Center \\
\hline 11. & $\begin{array}{l}\text { R.A. Schmitt, } \\
\text { W. Fredericks }\end{array}$ & Chemistry, 0.50 & High Purity Crystal Production & $\begin{array}{l}\text { Crystals Analyzed for Purity to Help } \\
\text { Explain Aberations on Light \& 0ther } \\
\text { Sources of Radiation }\end{array}$ & oSU Chemistry \\
\hline 12. & $\begin{array}{l}\text { R.A. Schmitt, } \\
\text { V.N. Smith }\end{array}$ & Chemistry, osu & Forensic Investigations & $\begin{array}{l}\text { INAA for Selected Trace El ements in } \\
\text { a Variety of Forensic Samples }\end{array}$ & $\begin{array}{l}\text { Oregon Law Enforce- } \\
\text { ment Agencies }\end{array}$ \\
\hline 13. & $\begin{array}{l}\text { R.A. Schmitt, } \\
\text { T. Fukuoka }\end{array}$ & Chemistry, 0sU & $\begin{array}{l}\text { El emental Abundances in Meteoritic } \\
\text { Specimens }\end{array}$ & $\begin{array}{l}\text { INAA \& RNAA of Selected Chondrules } \\
\text { to Determine REE, Sr, and BG Content } \\
\text { in Meteorites }\end{array}$ & NASA \\
\hline
\end{tabular}


Table IV-6 (continued)

\begin{tabular}{|c|c|c|c|c|c|}
\hline $\begin{array}{l}\text { Listing } \\
\text { Number }\end{array}$ & $\begin{array}{l}\text { Name of Person(s) } \\
\text { Using Reactor }\end{array}$ & $\begin{array}{l}\text { Department and } \\
\text { Institution }\end{array}$ & Project Title & Description & Funding Agency \\
\hline 14. & R.A. Schmitt & Chemistry, asu & Róck Studies of Terrestrial Basalts & INAA of Terrestrial Basaltic Rocks & MASA \\
\hline 15. & A.H. Robinson & Nuclear Engr. & $\begin{array}{l}\text { Neutron Radiography Studies of } \\
\text { Liquid Propellants }\end{array}$ & $\begin{array}{l}\text { Development of High Speed Neutron } \\
\text { Radtography of Burning Propellants }\end{array}$ & 000 \\
\hline 16. & W. Loveland & Chemistry, osu & $\begin{array}{l}\text { Radiochemical Studies of Low Energy } \\
\text { \& Relativistic Heavy Ion Reactions }\end{array}$ & $\begin{array}{l}\text { To Measure Mass, Charge, Angular, } \\
\text { Energy, \& Momentum Distributions } \\
\text { by NAA of Target Materials }\end{array}$ & USDOE \\
\hline 17. & W. Loveland & Chemistry, 0sU & $\begin{array}{l}\text { Hillamette River Tracer Experiment } \\
\text { for Pollutants }\end{array}$ & $\begin{array}{l}\text { Develop a Tracer Method for Tracing } \\
\text { Fluid Bound Substances in Fresh } \\
\text { Water }\end{array}$ & USDI \\
\hline 18. & W. Loveland & Chemistry, 0jU & $\begin{array}{l}\text { Atmospheric Trace Elements Assoc- } \\
\text { iated With Forest Fires }\end{array}$ & $\begin{array}{l}\text { INAA of Atmospheric Air Samples of } \\
\text { Forest Fires \& Slash Burning }\end{array}$ & Water Resources \\
\hline 19. & W. Loveland & Chemistry, 0;U & Herbicide Tracing & $\begin{array}{l}\text { Use of Tracers to Monitor Herbicide } \\
\text { Dispersal }\end{array}$ & USDI \\
\hline 20. & W. Loveland & Chemistry, $0=0$ & $\begin{array}{l}\text { Hydrospheric Trace Elements and } \\
\text { Their Use in Water Pollutant } \\
\text { Tracers }\end{array}$ & $\begin{array}{l}\text { Development of a Cheap, Fast Means } \\
\text { of Tracing the Behavior of Fluid- } \\
\text { Bound Substances in Natural Waters, } \\
\text { Such as Rivers. }\end{array}$ & U.S. Dept. of Interior \\
\hline $2 \mathbf{l}$. & W. Loveland & Chemistry, osu & $\begin{array}{l}\text { Precipitation Scavenging of } \\
\text { Tracers Released into Frontal } \\
\text { Storms }\end{array}$ & $\begin{array}{l}\text { Analyze for Trace El ements in Rain } \\
\text { Water Using NAA }\end{array}$ & Air Resources Center \\
\hline 22. & $\begin{array}{l}\text { W. Loveland } \\
\text { K. Keasler }\end{array}$ & Chemistry, $0 \leqq U$ & $\begin{array}{l}\text { Hydrospheric Trace Elements in } \\
\text { Water Pollutant Tracing for } \\
\text { Thesis (PhD) }\end{array}$ & $\begin{array}{l}\text { Activable Tracers Being Developed } \\
\text { to Trace Soluble Materials in an } \\
\text { Estuarine Environment }\end{array}$ & USDI \\
\hline 23. & S.E. Binney & $\begin{array}{l}\text { Nuclear Engr., } \\
\text { OSU }\end{array}$ & $\begin{array}{l}\text { Extraction of Uranium From Sea } \\
\text { Water }\end{array}$ & $\begin{array}{l}\text { Various Methods and Materials for } \\
\text { the Extraction of Uranium from } \\
\text { Seawater are Being Tested and } \\
\text { Analyzed }\end{array}$ & $\begin{array}{l}\text { Exxon Nuclear } \\
\text { research grant }\end{array}$ \\
\hline 24. & S.E. Binney & $\begin{array}{l}\text { Nuclear Engr., } \\
\text { OSU }\end{array}$ & $\begin{array}{l}\text { NAA in the Zirconium Metals } \\
\text { Industry for Uranium/Thorium }\end{array}$ & $\begin{array}{l}\text { INAA of Samples From the Plant } \\
\text { Streams \& Sludge Ponds in a } \\
\text { Zirconium Separation Plant }\end{array}$ & $\begin{array}{l}\text { Teledyne. Wah Chang } \\
\text { Albany research grant }\end{array}$ \\
\hline 25 . & S.E: Binney & $\begin{array}{l}\text { Nuclear Engr., } \\
\text { OSU }\end{array}$ & "Fluorine". & $\begin{array}{l}\text { INAA of Zirconium Salts for } \\
\text { Selected Elements }\end{array}$ & $\begin{array}{l}\text { Teledyne Wah Chang } \\
\text { Al bany research grant }\end{array}$ \\
\hline 26. & $\begin{array}{l}\text { S.E. Binney } \\
\text { A.G. Johnson }\end{array}$ & $\begin{array}{l}\text { Nuclear Engr., } \\
\text { OSU }\end{array}$ & Thorium Assay & $\begin{array}{l}\text { Thorium Assay in Tissue by } \\
\text { Delayed Neutron Counting }\end{array}$ & OSU Radiation Center \\
\hline
\end{tabular}


Table IV-6 (continued)

\begin{tabular}{|c|c|c|c|c|c|}
\hline $\begin{array}{l}\text { Listing } \\
\text { Humber }\end{array}$ & $\begin{array}{l}\text { Name of Person(s) } \\
\text { Using Reactor }\end{array}$ & $\begin{array}{l}\text { Department and } \\
\text { Institution }\end{array}$ & Project Title & Description & Funding Agency \\
\hline 27. & $\begin{array}{l}\text { A.G. Johnson } \\
\text { R. Poeton }\end{array}$ & $\begin{array}{l}\text { OSU General } \\
\text { Science }\end{array}$ & $\begin{array}{l}\text { Effect of Cadmium Ratio on TLD } \\
\text { Flux Calibrations }\end{array}$ & $\begin{array}{l}\text { To Study the Variation of TLD Response } \\
\text { to Thermal Neutrons as a Function of } \\
\text { Cadmium Ratio }\end{array}$ & OSU Radiation Center \\
\hline 28. & J.P. Barton & $\begin{array}{l}\text { Nuclear Engr., } \\
\text { OSU }\end{array}$ & $\begin{array}{l}\text { Evaluate Neutron Radiography } \\
\text { Capabilities for Reactor } \\
\text { Analysis and Safety Program }\end{array}$ & $\begin{array}{l}\text { Devel opinent of Neutron Radiography of } \\
\text { Large Fuel Bundles Inside Substantial } \\
\text { Steel Shrouds; The Results will be } \\
\text { Specifically Relevant to the Fast } \\
\text { Breeder Reactor Systellis }\end{array}$ & ANL \\
\hline 29. & K.S. Krane & Physics, OSis & $\begin{array}{l}\text { Angular Correlation Measurements } \\
\text { of Nuclear Gamma Ray }\end{array}$ & $\begin{array}{l}\text { Nuclear Spectroscopic Study of Excited } \\
\text { States in Odd-Mass Spherical Nuclei by } \\
\text { Gamma-Gamma Angular Correlation Tech- } \\
\text { nique }\end{array}$ & $\begin{array}{c}\text { OSU Physics Department } \\
.\end{array}$ \\
\hline 30. & R.M. Knaus & $\begin{array}{l}\text { Radiation Center } \\
\text { OSU \& Louisiana } \\
\text { State University }\end{array}$ & $\begin{array}{l}\text { Lanthanum \& Molybdenum Sorption } \\
\text { in Willow Roots }\end{array}$ & $\begin{array}{l}\text { INAA of Roots Exposed to La and Mo to } \\
\text { Determine Sorp to the Root Surface }\end{array}$ & OSU Radiation Center \\
\hline 31. & $\begin{array}{l}\text { J. Dymond } \\
\text { R. Cobler }\end{array}$ & $\begin{array}{l}\text { Oceanographs, } \\
\text { OSU }\end{array}$ & $\begin{array}{l}\text { Galapagos Rise Hydrology Study } \\
\text { For Thesis (Ph.D) }\end{array}$ & Geochemical Study of Galapagos by NAA & NSF \\
\hline 32. & J. Corliss & $\begin{array}{l}\text { Oceanography, } \\
\text { OSU }\end{array}$ & Galapagos Project & $\begin{array}{l}\text { INAA for Trace Metals of Trench Rock } \\
\text { and Mn Crust, Sediments \& Hydrothermal } \\
\text { Deposits }\end{array}$ & NSF \\
\hline 33. & J.C. Laul & Battelle NW & Lunar Chemical Characterization & $\begin{array}{l}\text { INAA for Chemical Study of Lunar and } \\
\text { Meteorite Samples }\end{array}$ & $\begin{array}{l}\text { ERDA prime contract } \\
\text { EY-76-C-06-1830, sp. } \\
\text { agreement } \mathrm{B}-29210-\mathrm{KF}\end{array}$ \\
\hline 34. & $\begin{array}{l}\text { G.G. Goles } \\
\text { MacCaskie }\end{array}$ & $\begin{array}{l}\text { Geology, Univ. } \\
\text { of Oregan }\end{array}$ & Bushveld Granites: Petrogenesis & $\begin{array}{l}\text { Study of Granites of the Bushveld } \\
\text { Complex. South Africa }\end{array}$ & $\begin{array}{l}\text { Geological Society of } \\
\text { America }\end{array}$ \\
\hline 35. & G.G. Goles & $\begin{array}{l}\text { Geology, Uniy. } \\
\text { of Oregon }\end{array}$ & Rockwell Hanford Analys is & $\begin{array}{l}\text { Determination of Compositions of } \\
\text { Columbia River Basalts. Purpose to } \\
\text { see if Safe Reservoirs for Disposal } \\
\text { of Radioactive Waste can be Found }\end{array}$ & DOE \\
\hline 36. & $\begin{array}{l}\text { G.G. Goles } \\
\text { G. Nixon }\end{array}$ & $\begin{array}{l}\text { University of } \\
\text { British Colurnbia } \\
\text { Through Univer- } \\
\text { sity of Oregon }\end{array}$ & WACK-I for Thes is (Ph.D) & $\begin{array}{l}\text { Dynamic Geochemistry of Iztacc ihuatl } \\
\text { (Snowy-Broad) }\end{array}$ & $\begin{array}{l}\text { University of Oregon } \\
\text { \& University of } \\
\text { British Columbia }\end{array}$ \\
\hline 37. & G.G. Goles & $\begin{array}{l}\text { Geology, Unis. } \\
\text { of Oregon }\end{array}$ & No Name & $\begin{array}{l}\text { Trace Element Analysis of Rock } \\
\text { Powders for Coastal Mining Co. }\end{array}$ & University of Oregon \\
\hline 38. & $\begin{array}{l}\text { G.G. Goles } \\
\text { Mr. Weill }\end{array}$ & $\begin{array}{l}\text { University of } \\
\text { Oregon }\end{array}$ & $\begin{array}{l}\text { Experimental Petrology of } \\
\text { Na-Glasses }\end{array}$ & Test of Exp. Glasses for $\mathrm{Na}$ & $\begin{array}{l}\text { University of Oregon } \\
\& \text { NSF }\end{array}$ \\
\hline
\end{tabular}




\section{Table IV-6 (continued)}

\begin{tabular}{|c|c|c|c|c|c|}
\hline $\begin{array}{l}\text { Listing } \\
\text { Number }\end{array}$ & $\begin{array}{l}\text { Nanie of Person(s) } \\
\text { Using Reactor }\end{array}$ & $\begin{array}{l}\text { Department and } \\
\text { Institution }\end{array}$ & Project Title & Description & Funding Agency \\
\hline 39. & $\begin{array}{l}\text { G.G. Goles, } \\
\text { Mr. Martin }\end{array}$ & $\begin{array}{l}\text { McGill Univ. \& } \\
\text { Univ. of Oregon }\end{array}$ & $\begin{array}{l}\text { INAA of Mutton Bay Syenitic Complex } \\
\text { \& Associated Rodingites }\end{array}$ & $\begin{array}{l}\text { Trace \& Rare Earth Element Deter- } \\
\text { mination of Syenites \& Rodingites }\end{array}$ & $\begin{array}{l}\text { University of Oregon } \\
\text { \& McGill University }\end{array}$ \\
\hline 40. & $\begin{array}{l}\text { G.G. Goles, } \\
\text { P. Robinson }\end{array}$ & $\begin{array}{l}\text { Univ. of Cal. } \\
\text { (Riverside) }\end{array}$ & $\begin{array}{l}\text { Investigation of Rocks of the John } \\
\text { Day Fm.. Oregon }\end{array}$ & $\begin{array}{l}\text { INAA of Selected Rock Samples for } \\
\text { Petrologie Interpretations }\end{array}$ & $\begin{array}{l}\text { University of Oregon } \\
\& \text { Univ. of Cal. } \\
\text { (Riverside) }\end{array}$ \\
\hline 41. & $\begin{array}{l}\text { G.G. Goles, } \\
\text { C. White }\end{array}$ & $\begin{array}{l}\text { Geology, Unil. } \\
\text { of Oregon } \\
\text {. }\end{array}$ & $\begin{array}{l}\text { Geological and Geochemical Survey } \\
\text { of Young Cascade Volcanisms for } \\
\text { Thes is (Ph.0) }\end{array}$ & $\begin{array}{l}\text { INAA of Selected Volcanic Specimens } \\
\text { from the Central Cascades (including } \\
\text { both Western Cascades and High Cas- } \\
\text { cades) of Oregon, Especially Mt. } \\
\text { Hood }\end{array}$ & $\begin{array}{l}\text { O.0.G.M.I. State of } \\
\text { Oregon }\end{array}$ \\
\hline 42. & $\begin{array}{l}\text { G.G. Goles, } \\
\text { H.R. Naslund }\end{array}$ & $\begin{array}{l}\text { Geology, Unib. } \\
\text { of Oregan }\end{array}$ & $\begin{array}{l}\text { Petrology of the Upper Border Group } \\
\text { of the Skaergaard Intrusion }\end{array}$ & $\begin{array}{l}\text { INAA Trace Element Analysis to } \\
\text { Correiate Upper Border Group } \\
\text { to Major Element Data }\end{array}$ & NSF \\
\hline 43. & $\begin{array}{l}\text { G.G. Goles, } \\
\text { N.I. Bishop, } \\
\text { J. Metz }\end{array}$ & $\begin{array}{l}\text { University of } \\
\text { Oregon }\end{array}$ & $\begin{array}{l}\text { A Study of Photosynthetic Apparatus } \\
\text { in Green Algae }\end{array}$ & $\begin{array}{l}\text { Determination of Manganese Levels } \\
\text { in Photosynthetic Membranes of Hild } \\
\text { Type \& Mutant Algae }\end{array}$ & NSF \\
\hline 44. & $\begin{array}{l}\text { G.G. Goles, } \\
\text { Mr. Stormer, } \\
\text { Mr. Roberts }\end{array}$ & $\begin{array}{l}\text { Geology, Unis. } \\
\text { of Oregon } \\
\text { Through Univ. } \\
\text { of Georgia }\end{array}$ & $\begin{array}{l}\text { INAA of Granite Rocks for Thesis } \\
\text { Work }\end{array}$ & $\begin{array}{l}\text { INAA of Ore Samples Related to } \\
\text { Mr. Roberts Thesis }\end{array}$ & $\begin{array}{l}\text { NSF Through the Univ. } \\
\text { of Georgia }\end{array}$ \\
\hline 45. & $\begin{array}{l}\text { G.G. Goles, } \\
\text { Mr. Loeschke }\end{array}$ & $\begin{array}{l}\text { University or } \\
\text { Tubigen } \\
\text { (Germany) } \\
\text { Through Univ. } \\
\text { of Oregon }\end{array}$ & $\begin{array}{l}\text { Investigation of Oregon Basalts in } \\
\text { Relation to Their Tectonic Setting }\end{array}$ & $\begin{array}{l}\text { INAA of Selected Geological Basalts } \\
\text { of the Pacific Northwest }\end{array}$ & University of Oregon \\
\hline 46. & $\begin{array}{l}\text { V. Trommsdorf, } \\
\text { 8. Evans, } \\
\text { G.G. Goles }\end{array}$ & $\begin{array}{l}\text { Geology, Unit. } \\
\text { of Oregon } \\
\text { Through Univ. } \\
\text { of Washingtor }\end{array}$ & $\begin{array}{l}\text { Regional \& Contact Metamorphism, } \\
\text { Swiss Alps }\end{array}$ & $\begin{array}{l}\text { Petrogenesis of Metamorphic Rocks } \\
\text { in the Swiss Alps }\end{array}$ & University of Oregon \\
\hline 47. & $\begin{array}{l}\text { G.G. Goles, } \\
\text { Mr. Crawford }\end{array}$ & $\begin{array}{l}\text { Geology, } \\
\text { University or } \\
\text { Oregon }\end{array}$ & INAA of Metavolcanics From Penn. & $\begin{array}{l}\text { To Determine Meta Somatic Changes } \\
\text { Between Anphibolite \& Granulite } \\
\text { Facres Using Trace \& Rare Earths }\end{array}$ & University of Oregon \\
\hline 48. & $\begin{array}{l}\text { G.G. Goles, } \\
\text { S. Goldberg }\end{array}$ & $\begin{array}{l}\text { Geology, Unit. } \\
\text { of Oregon }\end{array}$ & $\begin{array}{l}\text { Anorthosites of the Adirondachs } \\
\text { Thesis (Ph.D) }\end{array}$ & $\begin{array}{l}\text { INAA of Selected Geological Samples } \\
\text { From Adirondachs, New York }\end{array}$ & University of Oregon \\
\hline 49. & $\begin{array}{l}\text { G.G. Goles, } \\
\text { C. Bow }\end{array}$ & $\begin{array}{l}\text { Geology, Univ. } \\
\text { of Oregon }\end{array}$ & $\begin{array}{l}\text { Geochemistry and Petrogenes is } \\
\text { of Galapagos Lavas for Thesis } \\
\text { (Ph.D) }\end{array}$ & $\begin{array}{l}\text { INAA of Selected Rock Samples for } \\
\text { Trace El einent Analys is }\end{array}$ & University of Oregon \\
\hline
\end{tabular}


Table IV -6 (continued)

\begin{tabular}{|c|c|c|c|c|c|}
\hline $\begin{array}{l}\text { Listing } \\
\text { Number }\end{array}$ & $\begin{array}{l}\text { Name of Person(s) } \\
\text { Using Reactor }\end{array}$ & $\begin{array}{l}\text { Department and } \\
\text { Institution }\end{array}$ & Project Title & Description & Funding Agency \\
\hline 50 . & $\begin{array}{l}\text { G.G. 3oles, } \\
\text { Mr. Luhr }\end{array}$ & $\begin{array}{l}\text { Geology, Univ. } \\
\text { of Oregon }\end{array}$ & $\begin{array}{l}\text { Siliccous Volcanics in the Mexican } \\
\text { Volcanic Belt }\end{array}$ & $\begin{array}{l}\text { NAA of Airfall Pumice \& Ash } \\
\text { Flow Deposits in the Mexican Belt }\end{array}$ & University of Oregon \\
\hline E1. & $\begin{array}{l}\text { G.G. Joles, } \\
\text { Mr. Herring }\end{array}$ & $\begin{array}{l}\text { Geology, Univ. } \\
\text { of Oregon }\end{array}$ & SE Oregon Volcanic Study & $\begin{array}{l}\text { NAA of Rock Samples to Determine } \\
\text { Petrologic History of the Volcanics }\end{array}$ & University of Oregon \\
\hline 52 . & $\begin{array}{l}\text { G.G. Goles, } \\
\text { B. Baker }\end{array}$ & $\begin{array}{l}\text { Geology, Univ. } \\
\text { of Oregon }\end{array}$ & $\begin{array}{l}\text { Study of Petrogenes is of Mount } \\
\text { Kenya Lavas }\end{array}$ & $\begin{array}{l}\text { INAA of Selected Geological Samples } \\
\text { on Mt. Kenya }\end{array}$ & University of Oregon \\
\hline
\end{tabular}


C. PUBLICATIONS RESULTING FROM OSTR OPERATIONS THAT WERE REPORTED TO THE RADIATION CENTER

1. Publications in Print

Ma M.-S. and R.A. Schmitt 1979. Genesis of the cumulate eucrites Serra de Mage and Moore County. Meteoritics, $14,81-90$.

Ma M.-S. and R.A. Schmitt 1979. A chemical review of the various types of lunar mare low $K$ basalts. In Lunar and Planetary Science $X$, Lunar and Planetary Science Institute, Houston, Texas, pp. 753-755.

Wentworth S., G.J. Taylor, R.D. Warner, K. Keil, M.-S. Ma and R.A. Schmitt.1979. The unique nature of Apol10 17 VLT mare basalts. In Lunar and $\mathrm{Pl}$ anetary Science $X$, Lunar and Planetary Science Institute, Houston, Texas, pp. 1332-1334.

Ma M.-S. and R.A. Schmitt 1979. Chemistry of a new type of Apol10 11 low-K mare basalt. In Lunar and Planetary Science $\underline{X}$, Lunar and Planetary Science Institute, Houston, Texas, pp. 759-861.

Ma M.-S., R.A. Schmitt, R.D. Harner, G.J. Taylor and K. Keil 1979. Composition, petrography, and genes is of Apollo 17 high-Ti mare basalts. In Lunar and Planetary Science $X$, Lunar and Planetary Science Institute, Houston, Texas, pp. 765-767.

Ma M.-S., R.A. Schmitt, R.L. Nielsen, R.D. Warner, G.J. Taylor, and K. Keil 1979. Luna 16 basalts and breccias: new chemical and petrologic data. In Lunar and Planetary Science $X$, Lunar and Planetary Science Institute, Houston, Texas, pp. 762-764.

Ma M.-S. and R.A. Schmitt 1979. Chemistry of Tithic fragments from the Apollo 17 drill core sections 70004 and 70005 . In Lunar and Planetary Science $X$, Lunar and Planetary Science Institu.te, Houston, Texas, pp. 756-758.

Gooding J.L., T. Fukuoka, K. Keil and R.A. Schmitt 1979. Refractory and siderophile element variations among chondrules: evidence for primary compositional differences. In Lunar and Planetary Science X, Lunar and Planetary Science Institute, Houston, Texas, pp. 443-445.

Scherpelz R.I. and S.E. Binney 1978. "A Review of the Delayed Fission Neutron Technique," Nuclear Instruments and Methods, 154, 413 (1978). 
2. Publications in Press

Ma M.-S., R.A. Schmitt, R.L. Nielsen, G.J. Taylor, and R.D. Warner 1979. Petrogenes is of Lunar 16 aluminous mare basalts. J. Geophys. Res. Letts. (submitted).

Warner R.D., G.J. Taylor, G.H. Conrad, H.R. Northrup, S. Barker, K. Keil, M.-S. Ma and R.A. Schmitt 1979. Apollo 17 high-Ti mare basalts: new bulk compositional data, magma types, and petrogenesis. Proc. Lunar and Planet. Sci. Conf. 10th, Geochim. Cosmochim. Acta. Supp7. 10 (in press).

Beaty D.W., S.M.R. Hi1l, A.L. Albee, M.-S. Ma and R.A. Schmitt 1979. The petrology and chemistry of basaltic fragments from the Apol10 11 soil, Part I. Proc. Lunar and Planet. Sci. Conf. 10th Geochim. Cosmochim. Acta Suppl. 10 (in press).

Fodor R.V., J.L. Berkley, K. Keil, J.W. Husler, M.-S. Ma and R.A. Schmitt 1979. Petrology and chemistry of basalt drilled from the Galapagos spreading center, DSDP Leg 54. Initial Reports of the Deep Sea Drilling Project $V$. Washington (U.S. Geol. Printing Office), (in press).

Curtis D.B. and R.A. Schmitt 1979. The petrogenesis of L-6 chondrites-insights from the chemistry of minerals. Geochim. Cosmochim. Acta (in press).

Tinsley I.J. and R.R. Lowry 1979. "Bromine Content of Lipids of Marine Organisms," Journal of American 0i] Chemists Society (in press).

3. Reports and Papers

J.P. Barton 1978. "Feasibility of Neutron Radiography for Large Bundles of Fast Reactor Fuel," IRT Corporation. Final Report \#6247-004, IRT Corp., Box 80817, San Diego, Californía, 92138 .

A.G. Johnson and R. Poeton 1979. "The Influence of Cadmium Ratio on Thermal Neutron Measurements with TLD-600 Lithium Fluoride Thermoluminescent Dosimeters," Radiation Center Project Report, Oregon State University.

G.G. Goles (Dept. of Geology, University of Oregon) 1978. Final Report of subcontract SA-911 of Prime Contract No. EY-77-C-06-1030 for: Rockwell International Corporation, Atorics International Division, Rockwell Hanford Operations, Richland, Washington 99352. 
NOTE: This report by Dr. Goles may be of interest to those that may be (or are) involved in underground high-level waste storage. His findings suggest sub-surface basalts, under and near the Hanford reservation, probably were affected by alternation processes. This condition may strongly suggest that the storage of nuclear wastes in deep chambers, hollowed out within basalts, may not be a simple matter, and may be undesirable as contaminants could conceivably be brought back to or near the surface environment.

D. COMMERCIAL OR NON-ACADEMIC UTILIZATION

None

E. PUBLIC RELATIONS

The continued interest of the general public in the TRIGA reactor is evident in the number of people who have toured the facility. In addition to several hundred visitors during university open house events and interested individuals who happened to be in the vicinity, an estimated 1,095 people were given pre-planned and scheduled tours this fiscal year. See Table IV-7 for scheduled visitor statistics.

F. PLANNED CHANGES IN UTILIZATION

One shift ( 40 hours per week) operation is the current OSTR utilization mode. This can and will increase, however, depending upon the demand for OSTR time. 


\section{Table IV-7 \\ RADIATIÓN CENTER SCHEDULED VISITORS \\ July 1,1978 - June 30, 1979}

DATE

NAME

NO. OF

VISITORS

$\begin{array}{ll}10-06-78 & \text { Willamina High School } \\ 10-12-78 & \text { American Nuclear Society } \\ 11-21-78 & \text { American Society for Metals } \\ 11-30-78 & \text { Oakridge High School } \\ 12-02-78 & \text { American Nuclear Society Student Chapter } \\ 12-18-78 & \text { NET Workshop } \\ 1-27-79 & \text { Beaver Open House } \\ 1-29-79 & \text { NE 102x } \\ 2-02-79 & \text { Oregon House Committee on Energy \& Environment } \\ 3-05-79 & \text { Cub Scouts } \\ 3-19-79 & \text { NET Workshop } \\ 3-28-79 & \text { Japanese Peace Rally Team } \\ 4-04-79 & \text { Youth Energy Awareness Day } \\ 4-05-79 & \text { LBCC } \\ 4-10-79 & \text { ESPREE Day } \\ 4-12-79 & \text { OSU - English Language Institute } \\ 4-18-79 & \text { Salem Academy } \\ 4-20-79 & \text { Vernonia High School } \\ 4-23-79 & \text { LBCC } \\ 4-24-79 & \text { LBCC } \\ 4-25-79 & \text { LBCC } \\ 4-27-79 & \text { Oregon Elementary School Teachers } \\ 5-04-79 & \text { Mom's Weekend } \\ 5-08-79 & \text { OSU - Chemical Engineering 351 } \\ 5-10-79 & \text { OSU - Industrial Arts } \\ 5-11-79 & \text { Hidden Valley High School } \\ 5-11-79 & \text { Grants Pass High School } \\ 5-15-79 & \text { OSU - English Language Institute } \\ 5-18-79 & \text { OSU - Chemistry 206 } \\ 5-18-79 & \text { Monroe Union High School } \\ 5-22-79 & \text { Chemeketa } \\ 5-24-79 & \text { Gardner Junior High School } \\ 5-30-79 & \text { Western View Junior High School } \\ 6-26-79 & \text { Pacific Power \& Light Company } \\ & \end{array}$

15

38

17

7

11

10

200

20

12

15

10

20

180

15

80

10

25

10

21

20

20

30

70

82

12

20

20

12

10

15

6

30

25

7

TO TAL $\quad 1,095$ 


\section{Environmental and Radiation Protection Data; JULY 1, 1978 - JUNE 30, 1979}


TABLE OF CONTENTS

$\underline{\text { Page }}$

V. Environmental and Radiation Protection Data; JULY 1, 1978 - JUNE 30, 1979 . . . . . . . . . . V-1

A. INTRODUCTION .......................

B. A SUMMARY OF THE NATURE AND AMOUNT OF RADIOACTIVE EFFLUENTS RELEASED OR DISCHARGED TO THE ENVIRONS BEYOND THE EFFECTIVE CONTROL OF THE LICENSEE AS MEASURED AT OR PRIOR TO THE POINT OF SUCH RELEASE OR DISCHARGE ........... .1

1. Liquid Waste (summarized on a monthly basis)..... V-1

(a) The radioactivity discharged during the reporting period .......... V-

(1) The total estimated quantity of radioactivity released (in curies) .... . . V V-1

(2) The detectable radionuclides present in this waste.............. V-2

(3) An estimate of the specific activity for each detectable radionuclide present if the specific activity of the released material after dilution was greater than $1 \times 10^{-7}$ microcuries/cubic centimeter.

(4) A summary of the total release (in curies) for each radionuclide determined in (2) above for the reporting period, based on representative isotopic analysis....

(5) The estimated average concentration of the released radioactive material at the point of release for the reporting period (in terms of microcuries/cubic centimeter) and the fraction of the applicable MPC value..........

(b) The total volume (in gallons) of effluent water (including diluent) released during each period of release 
2. Gaseous Waste (summarized on a monthiy basis) . . . V-2

(a) The radioactivity discharged during the

reporting period............. . V-2

(1) The total estimated quantity of radioactivity released (in curies). determined by an appropriate sampling and counting method

(2) The detectable radionuclides present in this waste............

(3) The total estimated quantity of Argon-41 released (in curies) during the reporting period based on data from an appropriate monitoring system . . . . .

(4) The estimated average atmospheric diluted concentration of Argon-41 released during the reporting period (in terms of microcuries/cubic centimeter) and the fraction of the applicable MPC value...............

(5) The total estimated quantity of radioactivity in particulate form with half-lives greater than eight days (in curies) released during the reporting period, as determined by an appropriate particulate monitoring system. ...............

(6) The average concentration of radioactive particulales with half-lives greater than eight days (in microcuries/cubic centimeter) released during the reporting

(7) An estimate of the average concentration of other significant radionuclides present in the gaseous waste discharge (in terms of microcuries/cubic centimeter) and the fraction of the applicable MPC value for the reporting period, if the estimated release was greater than $20 \%$ of the applicable MPC ....... 
Page

3. Solid Haste (summarized on an annual basis).... V-4

(a) The radioactivity discharged during the reporting period ........ $v-4$

(1) The total amount of solid waste packaged (in cubic feet) ..... . V-4

(2) The detectable radionuclides present in this waste........ $V-4$

(3) The total radioactivity in the solid waste (in curies)........ V-4

(b) The dates of shipment and disposition (if shipped off-site)......... $v-4$

C. AN ANNUAL SUMMARY OF THE RADIATION EXPOSURE RECEIVED BY FACILITY PERSONNEL AND BY VISITORS IN TERMS OF THE AVERAGE RADIATION EXPOSURE PER INDIVIDUAL AND THE GREATEST EXPOSURE PER INDIVIDUAL FOR EACH OF THE TWO GROUPS

D. AN ANNUAL SUMMARY OF THE RADIATION LEVELS AND THE LEVELS OF CONTAMINATION OBSERVED DURING ROUTINE SURVEYS PERFORMED AT THE FACILITY IN TERMS OF THE AVERAGE AND THE HIGHEST LEVELS .............. . . . . V 5

E. THE LOCATION AND MAGNITUDE OF 'THE MAXIMUM MEASURED OR CALCULATED DIRECT RADIATION LEVEL IN UNRESTRICTED AREAS DUE TO DIRECT RADIATION FROM THE FACILITY, AND DIRECT RADIATION FROM FACILITY EFFLUENTS : . . . . V V -5

1. The Maximum Direct Radiation Level in Unrestricted Areas Due to Direct Radiation From the Facility................ V-5

2. The Maximum Direct Radiation [evel in Unrestricted Areas Due to Direct Radiation From Facility Effluents

F. AN ANNUAL SUMMARY OF THE GENERAL METHODS AND THE RESULTS OF ENVIRONMENTAL SURVEYS PERFORMED OUTSIDE THE FACILITY

1. The Onsite Environmental Monitoring Systems . . V-16

2. The Offsite Environmental Monitoring Systems . . V-21 


\section{LIST OF TABLES AND FIGURES}

Table or

Figure \# Title

Table V-1 Monthly Summary of Liquid Waste Discharges for the Year July 1, 1978 through June 30,

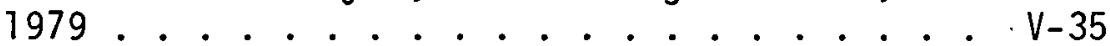

Table V-2 Monthly Summary of Gaseous Waste Discharges

for the Year July 1, 1978 through June 30,

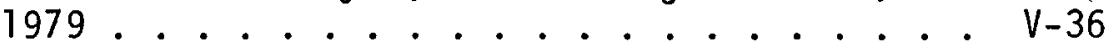

Table V-3 Annual Summary of Solid Waste Discharges for the Year July 1, 1978 through June 30, 1979 . V-37

Table V-4 Annual Summary of Radiation Exposure Received by Facility Personnel and Visitors for the Year July 1, 1978 through June 30,1979 . . V-38

Table V-5 Annual Summary of Radiation Levels and Contamination Levels Observed During Routine Radiation Surveys for the Year July 1, 1978 through June 30,1979 .......... . V-39

Fig. V-1 Operating-Area Film Badge Monitor Locations for the TRIGA Reactor .......... V-40

Fig. V-2 Area Radiation Monitor Locations for the TRIGA and AGN Reactors, and the TRIGA Reactor Area Fence........... V-4T

Table V-6 Total Dose Equivalent Recorded on OperatingArea Film Badge Monitors Located Inside the TRIGA Reactor Facility for the Year July 1. 1978 through June 30,1979

Table V-7 Total Dose Equivalent at the TRIGA Reactor Area Fence for the Year July 1, 1978 through June 30,1979

Fig. V-3 Monitoring Stations for the OSU TRIGA Reactor, January 6, 1976 through June 30,1979 ... V V44

Table V-8 Annual Average Concentrations of Gross Beta Radioactivity for Offsite Environmental Soil, Water, and Vegetation Samples for the Year July 7,1978 through June 30,1979

Table V-9 Annual Totals for Offsite Airborne Gamma Monitoring Stations for the Year July 1, 1978 through June 30,1979 .......... 
V. Environmental and Radiation Protection Data; July 1, 1978 THROUGH JUNE 30, 1979

A. INTRODUCTION

The data contained in this section have been prepared to comply with the requirements of Nuclear Regulatory Commission (NRC) Facility License No. R-106 (Docket No. 50-243) and the Technical Specifications contained in Appendix $A$ to that 1 icense, dated July 21,1976 . The material has also been prepared in compliance with Oregon Department of Energy Rule No. 345-30-010, which requires an annual report of environmental effects due to research reactor operations.

Within the scope of this program, all releases of radioactivity to the unrestricted environment and all occupational exposures to radiation and radioactive materials are consistently maintained "as low as reasonably achievable.".

B. A SUMMARY OF THE NATURE AND AMOUNT OF RADIOACTIVE EFFLUENTS RELEASED OR DISCHARGED TO THE ENVIRONS BEYOND THE EFFECTIVE CONTROL OF THE LICENSEE AS MEASURED AT OR PRIOR. TO THE POINT OF. SUCH RELEASE OR DISCHARGE

1. Liquid Waste (summarized on a monthly basis)

(a) The radioactivity in 1 iquid waste discharged during the applicable reporting period has been summarized according to the following items. All liquid waste data pertaining to these items are contained in Table V-1.

(1) The total estimated quantity of radioactivity released (in curies). 
(2) The detectable radionuclides present in this waste.

(3) An estimate of the specific activity for each detectable radionuclide present if the specific activity of the released material after dilution was greater than $1 \times 10^{-7}$ microcuries/cubic centimeter.

(4) A summary of the total release (in curies) for each radionuclide determined in (2) above for the reporting period, based on representative isotopic analysis.

(5) The estimated average concentration of the released radioactive material at the point of release for the reporting period (in terms of microcuries/cubic centimeter) and the fraction of the applicable MPC value.

(b) The total volume (in gallons) of effluent water (including diluent) released during each period when liquid waste was released is also summarized in Table $V-1$.

2. Gaseous Waste (summarized on a monthly basis)

(a) The radioactivity in gaseous waste discharged during the applicable reporting period has been summarized according to the following items. All gaseous waste data pertaining to these items are contained in Table V-2. 
(1) The total estimated quantity of radioactivity released (in curies) determined by an appropriate sampling and counting method.

(2) The detectable radionuclides present in this waste.

(3) The total estimated quantity of Argon-41 released (in curies) during the reporting period based on data from an appropriate monitoring sys.tem.

(4) The estimated average atmospheric diluted concentration of Argon-41 released during the reporting period (in terms of microcuries/ cubic centimeter) and the fraction of the applicable MPC value.

(5) The total estimated quantity of radioactivity in particulate form with half-lives greater than eight days (in curies) released during the reporting period, as determined by an appropriate particulate monitoring system.

(6) The average concentration of radioactive particulates with half-lives greater than eight days (in microcuries/cubic centimeter) released during the reporting period. 
(7) An estimate of the average concentration of other significant radionuclides present in the gaseous waste discharge (in terms of microcuries/cubic centimeter) and the fraction of the applicable MPC value for the reporting period, if the estimated release was greater than $20 \%$ of the applicabie MPC.

3. Solid Waste (summarized on an annual basis)

(a) The radioactivity in solid waste discharged during the applicable reporting period has been summarized according to the following items. All solid waste data pertaining to these items are contained in Table V-3.

(1) The total amount of solid waste packaged (in cubic feet).

(2) The detectable radionuclides present in this waste.

(3) The total radioactivity in the solid waste (in curies).

(b) The dates of shipment and disposition of solid wastes (if shipped off-site) are also contained in Table $V-3$.

C. AN ANNUAL SUMMARY OF THE RADIATION EXPOSURE RECEIVED BY FACILITY PERSONNEL AND BY VISITORS IN TERMS OF THE AVERAGE RADIATION EX-

$\therefore$ POSURE PER INDIVIDUAL AND THE GREATEST EXPOSURE PER INDIVIDUAL FOR EACH OF THE TWO GROUPS

The annual summary of the radiation exposure received by facility personnel and visitors for the applicable reporting period is contained in Table $V-4$. 
D. AN ANNUAL SUMMARY OF THE RADIATION LEVELS AND THE. LEVELS OF CONTAMINATION OBSERVED DURING ROUTINE SURVEYS PERFORMED. AT THE FACILITY IN TERMS OF THE AVERAGE AND THE HIGHEST LEVELS

The annual summary of radiation and contamination levels observed during routine facility surveys for the applicable reporting period is presented in Table $\mathrm{V}-5$.

E. THE LOCATION AND MAGNITUDE OF THE :IAXIMUM MEASURED OR CALCULATED DIRECT RADIATION LEVEL IN UNRESTRICTED AREAS DUE TO DIRECT RADIATION FROM THE FACILITY, AND DIRECT RADIATION FROM FACILITY EFFLUENTS

1. The Maximum Direct Radiation Level in Unrestricted Areas Due to Direct Radiation From the Facility

The location and magnitude of the maximum (measured and calculated) direct radiation level in the unrestricted area due to direct radiation from the facility can best be understood by referencing Figures $V-1$ and $V-2$, and Tables $V-6$ and V-7.

Early in the operating history of the OSU TRIGA reactor, two potential sources of direct radiation from the TRIGA facility were identified. These were the demineralizer tank for the reactor primary water system, and the graphite-natural uranium subcritical pile located in the main reactor room (see Figure $V-1)$.

The demineralizer tank was removed from its original position as indicated in Figure $V-1$ to location " $A$ " in Figure V-1 on January 3, 1972, and henceforth ceased to be a major contributor to the direct radiation from the facility. On February 23, 1972, the east side (the exterior wall side) 
of the subcritical pile and the entire demineralizer tank were conservatively shielded with concrete and lead, further limiting any small direct radiation contribution from the demineralizer tank, and effectively reducing the direct radiation to unrestricted areas from the subcritical pile and the demineralizer tank to essentially zero millirem per year.

With the elimination of the preceding two sources of direct radiation from the facility, two additional sources of lesser magnitude became apparent. One of these was the particulate filter for the reactor primary water system, which is located on the demineralizer platform. (see Figure $V-1)$, and the second is best collectively termed "normal use of reactor experimental facilities and operating areas for research and teaching."

The particulate filter was completely shielded by July 10, 1972, and the new shield el iminated any further radiation contribution to the unrestricted area from this source. The secund sunree, relating to normal use of the OSU research reactor, takes into consideration the routine handling of radioactive materials within the facility as a whole, and the need for relatively frequent access into reactor experimental and irradiation facilities. Both of . these latter activities create a small potential for low levels of direct radiation exposure of reactor facility origin in immediately adjacent. unrestricted areas. 
Direct radiation levels in unrestricted areas (which potentially may arise from the TRIGA facility) are evaluated on the basis of three different types of radiation measurements. First, direct radiation levels are measured and analyzed as part of our routine radiation survey program. Second, data from area monitoring film badges installed at strategic locations within the TRIGA reactor operating-area are routinely documented and utilized to indicate locations where direct radiation from the facility might be entering unrestricted areas. The film badge data are corrected, as appropriate, to reflect radiation attenuation in the reactor facility walls. Finally, assessment of the direct radiation levels in unrestricted areas is conducted on the basis of area monitoring data collected through our thermoluminescent dosimetry (TLD) program.

The locations of pertinent vendor supplied (the vendor being Radiation Detection Co. [R.D. Co.], Mt. View, California) beta-gamma-neutron area monitoring film badges inside the restricted operating-area at the OSU TRIGA facility are shown in detail in Figure $\mathrm{V}-1$, and are again shown as part of an overall area diagram in Figure $V-2$. Figure $V-2$ also shows the locations of R.D. Co., $\mathrm{CaSO}_{4}$ TLD area monitors, (started during the $1977-78$ reporting period, replacing the beta-gamma-neutron film packs used previously on the reactor area fence) plus OSU supplied and processed TLD area monitors 
(normaliy 3 Harshaw LiF TLD-700 chips per monitor). Both types of TLD area monitors are positioned on the fence surrounding the TRIGA reactor facility. This fence was originally installed in September 1972. Figure V-2 also shows the location of three R.D. Co. beta-gamma-neutron area monitoring film badges used in conjunction with the University's AGN reactor. The AGN reactor and its monitors are not part of this report.

With the addition of the fence around the reactor area, area monitoring film badge data from inside the TRIGA facility (contained in Table $V-6$ ) no longer have a high degree of correlation to direct radiation levels in surrounding unrestricted areas. Nevertheless, we believe the data from inside the facility reflect the general character of our operation and therefore plan to continue including it in all reports of this type.

In Figure $V-1$ and $V-2$, film badge locations within the TRIGA reactor facility are abbreviated to indicate their position on a north, south, east or west wall of the main reactor bay, or their location in the reaclur's adjacent heat exchanger room. For example, MRCTSE is interpreted as Monitor Radiation Center IRIGA, South badge, East wall of the main reactor bay building. Similarly, MRCTHXS is the badge for the adjacent Heat Exchanger room, South wall. Monitoring locations on the fence are simply designated MRCFE-1 through MRCFE-9, and imply Monitor Radiation Center Fence Environmental (TLD position number). 
After the addition of the previously described shielding and the reactor area fence, direct radiation levels in unrestricted areas due to the TRIGA facility dropped to essentially background levels. Data presented in Table $\dot{V}-6$ show the extremely low annual doses recorded inside the reactor facility's operating-area. Table V-7 provides verification. of the essentially normal annual radiation levels measured in the unrestricted areas, as recorded by the area monitoring TLD's located on the reactor area fence, and as indicated by the direct microroentgen per hour exposures rates taken at each area monitoring station. See footnote (7) of Table V-7 for a further explanation of the $\mu R / h r$ data and its application. We are continuing our efforts to achieve closer agreement between R.D. Co. and OSU TLD data. At the present time, R.D. Co. uses a considerably higher background than OSU, and they may be reporting dose accumulated during periods when their TLD's are not in service at OSU (e.g., during transportation, etc.). Present control and $Q A$ procedures used by OSU for its outside dosimetry vendor w111 continue to be carefully scrutinized, and will be modified as deemed necessary during the next year in order to isolate and el iminate suspected sources of vendor error, should they exist.

As a final note on the fence monitoring stations, it should be reported that there is little or no occupancy of any specific point on the perimeter of the fence throughout the entire year. 
2. The Maximum Direct Radiation Level in Unrestricted Areas Due to Direct Radiation From the Facility Effluents

The location and magnitude of the maximum (measured and calculated) direct radiation level in unrestricted areas due to direct radiation from facility effluents will be reviewed in light of both liquid and gaseous releases.

As reported in Table $\mathrm{V}-1$, the total annual quantity of radioactivity released in liquid effluents has been quite small. The microcurie quantity for the reporting period in even a few hundred cubic centimeters of solution would not normally present a significant direct radiation potential, particularly when the radionuclide composition of the radioactivity is examined. In our particular operation, the majority of the liquid radioactive effluent is now normally associated with a single annual demineralizer resin change. When released from the reactor facility, this liquid is mixed with up to 3000 gallons of waste water from the Radiation Center laboratories on a batch basis before final discharge into the unrestricted area (the sanitary sewer system).

The annual average concentration for total reactor facility radioactivity in liquid effluents entering the unrestricted area equaled $2.32 \times 10^{-6} \mathrm{\mu Ci} / \mathrm{cc}$ for the year July 1, 1978 through June 30, 1979. With respect to this value and the total radioactivity released in the liquid effluent, recall that no city water background radioactivity 
has been subtracted. Also, note that the main contributor to the microcuries released is tritium ( $22.4 \mu \mathrm{C} i$ ). Even though nearly all of the liquid effluent volume from the reactor facility now originates during the changing of demineralizer resins, which occurs about every 12 months, it appears that little, if any, of the tritium is of reactor origin. Our routine analysis of city water indicates a normal tritium background concentration within a range of $3.42 \times 10^{-5} \mu \mathrm{Ci} / \mathrm{CC}$ to $1.53 \times 10^{-6} \mu \mathrm{Ci} / \mathrm{CC}$ for the year Ju1y 1 , 1978 through June 30, 1979. Our annual average concentration for tritium based on all liquids released to the unrestricted area from the reactor facility is within this background range at $2.26 \times 10^{-6} \mu \mathrm{Ci} / \mathrm{CC}$ for the year July 1,1978 through June 30 , 1979. If the tritium is omitted from the total radioactivity released in the reactor's liquid effluent and a calculation performed using the remaining radioactivity $(\sim 0.55 \mu \mathrm{C} i)$, some of which is also city water background, the annual average concentration for reactor facility radioactivity entering the unrestricted area becomes $5.56 \times 10^{-8} \mu \mathrm{Ci} / \mathrm{cc}$ for the year July 1, 1978 through June 30, 1979.

In view of the radionuclides present, and the relative abundance of each, it can be easily determined (as shown in Table $V-1$ ) that the annual average concentration of total reactor facility radioactivity in 1 iquid effluents represents but a small fraction $(0.174 \%)$ of the appropriate unrestricted 
area maximum permissible concentration. In addition, the average concentration DOES NOT take into consideration the additional mixing with approximately 95,000 to 115,000 gallons per year of liquids and sewage normally discharged by the Radiation Center complex into the sanitary sewer system. For these reasons, we have concluded that the direct radiation to unrestricted areas due to radioactivity in reactor 1 iquid effluents has been negligible.

On pages 4-53 through 4-58 of the Safety Analysis Report (SAR) for the OSU TRIGA Research Reactor, dated August 1968, consideration is given to routine discharge and atmospheric dilution of gaseous effluents from the reactor facility. This particular analysis in the 1968 SAR was conducted using the original TRIGA facility stack height of 55 feet above ground level. On page 4-57 of this report, it is specified that the activity discharge rate assumed for the purpose of calculation was 100 MPC,

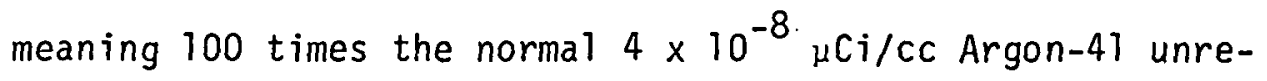
stricted area maximum permissible concentration, or a value of $4 \times 10^{-6} \mu \mathrm{Ci} / \mathrm{Cc}$. On page $4-58$ (Table 4.11 of the Safety Analysis Report) it is concluded that under the most unfavorable atmospheric conditions (with the 55 foot stack) a person standing for a full year at the point of maximum concentration would be exposed to less than $9 \%(8.53 \%)$ of the normal unrestricted area MPC for Argon-41. As a result, a person could stand at that point continuously for one 
year under the most unfavorable atmospheric conditions, while the reactor operated continuously at $1000 \mathrm{~kW}$, (and continuousiy discharged an assumed worst case concentration of $4 \times 10^{-6} \mu \mathrm{Ci} / \mathrm{cc}$ of Argon-41) and receive a whole body gamma dose from Argon-41 of 1 ess than 45 mrem (42.6 mrem) integrated over an entire year's occupancy.

Since the OSU TRIGA does not operate on a 24-hour per day basis, does not operate continuously at $1000 \mathrm{~kW}$ while it is operating, and does not discharge Argon-41 at $4 \times 10^{-6} \mu \mathrm{Ci} / \mathrm{CC}$ while operating at $1000 \mathrm{~kW}$, the annual average Argon-41 concentration, as measured by the facility stack monitor, has always been much less than the assumed calculational value of $4 \times 10^{-6} \mu \mathrm{Ci} / \mathrm{cc}$. Consequentiy, the maximum annual dose to the unrestricted area due to direct radiation from gaseous effluents has also been significantly less than the nominal 45 mrem per year value projected in the 1968 Safety Analys is Report.

As indicated in OSU's May 16, 1973 report of 10 CFR 50.59 items to the former USAEC Division of Reactor Licensing, (a copy of which also went to the former oregon Nuclear and Thermal Energy Council) on February 23, 1972 the TRIGA facility stack height was increased from its original 55 feet above the ground to 65 feet, 10 inches above ground level. As a result of the new stack height, new atmospheric dispersion calculations were necessary in order to evaluate the atmospheric dilution of gaseous effluents from the 
reactor facility. The results of the original 1968 calculations and the first evaluation following the stack change were included in Table 2 of OSU's May 16, 1973 report to the USAEC, and indicated a slightly lower concentration at the point of maximum concentration using the higher stack. Additional plume studies during 1973 and 1974, and again during 1978 using USNRC Regulatory Guide 1.111 , evaluated the influence of the new stack height on gaseous effluent dispersion, and essentially confirmed earlier data. Only a slight change is introduced if the most unfavorable values from the expanded 1973-74 and. newer 1978 study are used.

Using the same basic assumptions employed for the shorter stack, and in particular a continuous Argon-4l discharge rate of $100 \mathrm{MPC}$, the 1973-74 results indicate that for atmospheric conditions giving the highest ground concentration (i.e., the worst atmospheric conditions) a person standing at the point of maximum concentration would encounter approximately $3.018 \%$ (as opposed to $2.85 \%$ in the 1972 report) of the unrestricted area MPC for Argon-41. Furthermore, the 1978 study produced a nearly identical value of $3.005 \%$ of the unrestricted area Argon-41 MPC. As a result, a person could stand at this point of maximum concentration (currently projected to be 130 meters from the stack as opposed to 150 meters in the 1973-74 calculation, and 135 meters in 
the 1972 report) continuously for one year under the worst atmospheric conditions, while the reactor continuousty discharged 100 times the Argon-41 MPC, $\left(4 \times 10^{-6} \mu \mathrm{Ci} / \mathrm{CC}\right)$ and receive a whole body gamma dose from Argon-4l of 15 (15.03) mrem integrated over an entire year's occupancy. As we have indicated, the OSU TRIGA does not operate on a 24-hour per day basis, nor does it operate continuously at $1000 \mathrm{~kW}$. Also, the facility's annual average Argon-41 concentration is always much lower than the $4 \times 10^{-6} \mu \mathrm{Ci} / \mathrm{cc}$ value used for purposes of calculation. As a result, the maximum annual dose in the unrestricted area due to direct radiation from gaseous effluents consistently remains much less than the nominal $15 \mathrm{mrem}$ per year projected using the new stack height and the 1978 plume dispersion data.

In order to evaluate the maximum dose in the unrestricted area from gaseous effluents during the reporting period, one should assume continuous annual occupancy at the point of maximum concentration. Furthermore, it will be necessary to assume the existence of the most unfavorable meteorological conditions for a full year in order to achieve the maximum concentration at the specified point for one entire year. If these conservative assumptions are applied in conjunction with the reported annual average Argon-41 concentration, $\left(5.97 \times 10^{-8} \mu \mathrm{Ci} / \mathrm{CC}\right)$ as derived 
from actual measurements at the point of release with the facility's continuous stack monitor (see Table $\dot{V}-2$ ), then the maximum annual dose in the unrestricted area (at 130 meters from the stack under the most unfavorable atmospheric conditions) would be approximately $0.224 \mathrm{mrem}$ for the year July 1, 1978 through June 30, 1979.

F. AN ANNUAL SUIMARY OF THE GENERAL METHODS AND THE RESULTS OF ENVIRONMENTAL SURVEYS PERFORMIED OUTSIDE THE FACILITY

The environmental radiation monitoring program will be categorized according to onsite and offsite environmental monitoring systems. A description of the two categories follows.

1. The Onsite Environmental Monitoring Systems

Onsite radiation monitoring programs which we believe qualify as environmental radiation monitoring systems include the facility radioactivity stack monitor, onsite area monitoring film badges, TLD's and 0-200 mrem gamma-sensitive integrating ionization chambers (self-reading pocket dosimeter type), and the monitoring procedures associated with the analysis of radioactivity in liquid effluents from the reactor facility. Also, routine (daily, weekly, biweekly and monthly) direct radiation surveys conducted by the OSU TRIGA Radiation Protection Staff provide a weal th of essential information on existing radiation conditions throughout the various onsite areas. 
The reactor facility radioactivity stack monitoring system consists of a continuous moving-filter-paper particulate monitor, followed by a separate chamber which functions as a gas monitor. The system is consistently placed in operation before the reactor is started up, remains in operation at all times while the reactor is in use, and is kept operable after reactor shutdown until both detection channels reach normal background. The system is equipped with an isokinetic sampling head which draws its sample near the point of discharge in the reactor building stack. The system is calibrated at least annually with standardized particulate samples of appropriate types and energies, and with known quantities of Argon-41 gas. The system reads out continuously in both the particulate and gaseous channels, with each channel having its own count rate meter and recorder. A count integrating scaler is also attached to the gas channel to increase the accuracy of determining Argon-41 released. The system is equipped with alarm circuits which will automatically shut off the facility ventilation system and close dampers on the intake and exhaust lines in the event preset airborne radioactivity concentration limits are reached. One of the most valuable applications of this system from the standpoint of environmental monitoring is the data derived from its operation which 
can be applied to determining potential exposures in unrestricted areas from gaseous radioactive effluents. Onsite area monitoring film badges consist of standard personnel-type beta-gamma-neutron film packs, located at strategic positions inside the reactor facility operating-area (see figures $V-1$ and $V-2$ ). The films within the facility are changed once per month.

Onsite area monitoring using TLD's now consists of two different types of dosimeters, both located at identical positions on the reactor area fence (see Figure $(-2)$. One type of TLD monitor is supplied and interpreted by our vendor, Radiation Detection Company (R.D. Co.), Mt. View, California. The vendor supplied system utilizes $\mathrm{CaSO}_{4}$ TLD's prepackaged by R.D. Co., and exchanged on a quarterly basis. These dosimeters replace the R.D. Co: beta-gamma-neutron film packs previously used on the reactor area fence. The R.D. Co. TLD's are located in the same thin sheet metal boxes previously used to house the film packs, and are accompanied at each 10cation by the second TLD monitoring package which is prepared and interpreted by OSU. Each OSU TLD monitoring device normally consists of three lithium fluoride chips, presently Harshaw TLD-7.00's, exchanged on a quarterly basis. 
Prior to Apri1 1976, each onsite group of three OSU TLD chips was packaged first in a plastic mount which was then placed inside an outer container consisting of a thin walled copper tube. The copper tube was subsequently taped to the reactor area fence. The plastic mount and copper container were essentially identical to those presently being used by the Oregon Radiation Control Section in their TLD program. In April 1976, the copper tube outer containers were discontinued for the OSU supplied. TLD's on the reactor area fence, and the remaining inner plastic mounts were placed inside thin sheet metal boxes located at each of the reactor area fence monitoring stations. This was done to reduce data loss due to increasing theft of the small copper tube TLD packs. OSU and R.D. Co. TLD packs are currentiy located at each of the nine reactor area fence positions identified in Figure $V-2$.

In addition to the above monitoring devices, each of the nine reactor area fence monitoring positions is presently equipped with two $0-200 \mathrm{mrem}$ gamma-sensitive integrating ionization chambers (self-reading pocket dosimeter type). These dosimeters are located inside the thin sheet metal box at each fence monitoring station, which also contains the two different TLD monitoring packets. The ionization chamber dosimeters are read every two weeks and are used as backup monitors for each station. 
For the July 1,1978 through June 30,1979 reporting period, an additional onsite environmental monitoring program was conducted. This program involved the biweek1y (every 2 weeks) measurement of the direct radiation exposure rate in terms of microroentgens per hour $(\mu R / h r)$ at each reactor fence monitoring station. Measurements were taken with an Eberline Instrument Co. micro-R per hour rate meter containing a $1 " \times 1 " \mathrm{NaI}$ detector. The 26 annual readings were then averaged and ultimately converted to an expected (calculated) annual mrem dose equivalent for each location.

In terms of environmental monitoring, onsite area monitoring films, TLD's, integrating ionization chambers, and direct radiation exposure rate measurements at appropriate locations may be used to estimate maximum potential doses in nearby unrestricted areas due to direct radiation from the reactor facility. Normally, these estimates are made to reflect the annual dose equivalent which could be delivered in the unrestricted area assuming continuous occupancy, al though occupancy of unrestricted areas adjacent to the reactor facility is virtually zero throughout the year.

The routine analysis of gross radioactivity in liquid effluents (with isotopic identification as appropriate) prior to discharge into the unrestricted 
area allows evaluation of the reactor facility contribution to potential radiation exposures to the general public from this sourcè.

2. The Offsite Environmental Monitoring Systems

Offsite environmental monitoring systems useful as indicators of potential radiation dose in unrestricted areas due to reactor operations include a soil, water, and vegetation monitoring program, and an airborne gamma monitoring program.

The soil, water, and vegetation monitoring program centers around the collection of a 1 imited number of samples in each category on a quarterly basis. It is operated in conjunction with the reactor facility and the OSU Radiation Center, and considered useful for indicating general trends in gross radioactivity concentrations for the substances sampled. See Figure V-3 for the location of sampling positions for G-Grass, S-Soil, W-Water, and RW-Rain Water.

The airborne gamma monitoring program is generally described on pages 4-59 and 4-60 of the August 1968 Safety Analysis Report for the OSU TRIGA Reactor. As of January 1, 1975, nine additional offsite airborne gamma monitoring stations were implemented to increase the total number of these stations now in use to nineteen. See Figure $V-3$ for the location of the nineteen airborne gamma monitoring stations. 
As of January 1, 1975, the coding technique used to designate each specific offsite monitoring station was modified slightly to indicate the radiation monitoring devices present at a particular station. Under the new coding system, stations which contain only a standard OSU TLD monitoring pack (described previously in this report) will have an "L" after the station number. For example, MRCTE-2L is interpreted as Monitor Radiation Center IRIGA Environmental Station number 2 with a standard OSU TLD pack in a copper tube being the only monitoring device at this station. (NOTE: The copper tube outer container is still used for all OSU TLD packs employed in the offsite environmental monitoring program. They were discontinued only for the OSU TLD's used on the reactor area fence). At offsite stations where only an OSU TLD monitor is used, the copper tube containing the TLD's is taped directly onto a mounting post or other permanent object used to identify the monitoring station. Stations which have no "L" after the station number consist of a thin weather-tight aluminum box mounted on a post about four feet off the ground. Each of these stations include one R.D. Co. TLD pack, one standard OSU copper tube TLD monitoring pack identical to those previously described, and two 0-200 mrem gamma-sensitive integrating ionization chambers (self-reading pocket dosimeter type) as backup monitors. At these stations, 
the OSU TLD's are not enciosed inside the aruminum box, but instead the copper tube is taped directiy onto the box mounting post at the station. A11 TLD monitors in the offsite airborne gamma environmental monitoring program are exchanged on a quarterly interval beginning January 1 of each year. The ionization chamber (dosimeters) are read once every 2 weeks throughout the year. For the July 1, 1978 through June 30, 1979 reporting period, the previously described program for biweekly measurements of the direct radiation exposure rate in $\mu R / h r$ at each reactor fence monitoring station was extended to include each of the nineteen airborne gamma monitoring stations. The data was handled in the same manner as already mentioned and the objective was to derive an expected (calculated) annual mrem dose equivalent for each location based on an annual average $\mu R / h r$ exposure rate.

A summary of the environmental monitoring results for the year July 1, 1978 through June 30, 1979 is given below, and includes, as appropriate for the measurement under consideration:

(a) The number of sampling locations.

(b) The total number of samples per year. 
(c) The annual average concentration of gross radioactivity, and in some cases, concentrations of specific radionuclides in the medium being assayed.

(d) The total annual millirem of external radiation dose for a particular location as well as a general description of that location.

The data from the environmental monitoring systems will be arranged to correspond to the specific individual systems identified previously in conjunction with onsite and offsite programs.

Reactor Facility Stack Monitor, (onsite):

(a) The system has one sampling location as indicated previously.

(b) Samples are continuous; (i.e., prior to, during, and after reactor operation). It is normal for the stack monitor to begin operation as one of the first systems in the morning and to cease operation as one of the last systems at the end of a normal operating day.

(c) The annual average concentration of gross radioactivity based on the facility stack monitor is given in Table V-2. As indicated in this table, the only gaseous component identified has been Argon-41, 
and only naturally occurring particulate activity (radon daughter products) has been detected by the particulate channel: The normal concentration for the naturally occurring particulate daughters during the reporting period remained about the same as in previous years, and was within a range of $3.76 \times 10^{-10} \mu \mathrm{Ci} / \mathrm{cc}$ to $8.60 \times 10^{-12} \mu \mathrm{Ci} / \mathrm{cc}$. Reactor Facility Area Monitoring Film Badges, Reactor Fence TLD's, Integrating Ionization Chambers and Direct Radiation Measurements (onsite):

(a) There are presently eight applicable area monitoring film badges within the TRIGA reactor facility operating-area. There are also nine vendor (R.D. Co.) supplied $\mathrm{CaSO}_{4}$ TLD monitors plus nine standard OSU TLD monitoring packs and eighteen (2 per station) 0-200 mrem gamma-sensitive integrating ionizaliun chambers un lhe redilur: area fence. There are also nine specific locations (the fence monitoring stations) where routine biweekly $\mu \mathrm{R} / \mathrm{hr}$ measurements are made. All of these have application as onsite environmental monitors. 
(b) Since each film badge within the TRIGA facility is changed once per month, there is a total of 96 different samples of this type each year. Quarterly changes of the fence TLD monitors result in another. 36 vendor supplied TLD samples and 108 OSU TLD samples (9 stations $\times 3$ TLD chips per station $\times 4$ changes per year $=108$ samples) for these locations each year. The eighteen integrating ionization chambers are read once every two weeks and thus result in approximately 468 samples (readings) each year. There are a total of $26 \mu \mathrm{R} / \mathrm{hr}$ measurements made at each of the nine fence monitoring stations each year for a total of 234 such measurements annually.

(c) TRIGA internal sampling locations are identified in Figure $V-1$, with film badges being located on the inside of the indicated walls at approximately head height above the floor. Locations of the film badges are coded Monitor Radiation Center IRIGA, North badge, East wall (MRCTNE) and so on. Locations for the TRIGA internal film badges plus the 10cations of the fence monitors are shown in 
Figure $\mathrm{V}-2$. Fence monitoring locations are coded Monitor Radiation Center Fence Environmental-1 (MRCFE-1.) and so on through MRCFE-9. TLD monitors on the fence are in sealed moisture-resistant packages inside thin sheet metal mailboxes about four feet off the ground. The integrating ionization chambers are also contained in the metal boxes. Total annual levels of radiation exposure recorded at the area monitoring locations are given in Tables $V-6$ and $V-7$. Analysis of Reactor Contributed Radioactivity in Liquid Effluents, (onsite):

(a) TRIGA liquid effluent is analyzed before release to a collection point, and is anaryzed again in conjunction with other radioactivity prior to discharge from the collection point into the unrestricted area.

(b) The tuld l number of samples were as follows: July 1, 1978 through June 30, $1979=$ ? reactor liquid effluent sample before release to the collection point.; July 1, 1978 through June 30 , $1979=1$ reactor liquid effluent sample before release from the collection point to the unrestricted area. 
(c) The liquid effluent data for environmental. assessment have been summarized for the reporting period in Table $V-1$. Section $V-E-2$ of this report also addresses the estimated level of external radiation from radioactivity in liquid effluent.

Soil, Water and Vegetation Monitoring Program, (offsite):

(a) For this program there are now a total of 22 sampling locations: 4 soil locations, 4 water locations (when water is available), and 14 végetation locations.

(b) Samples (as available) are taken at each location on a quarterly basis. Samples have been collected as follows:

$$
\text { july } 1,1978 \text { through }
$$
June 30,1979

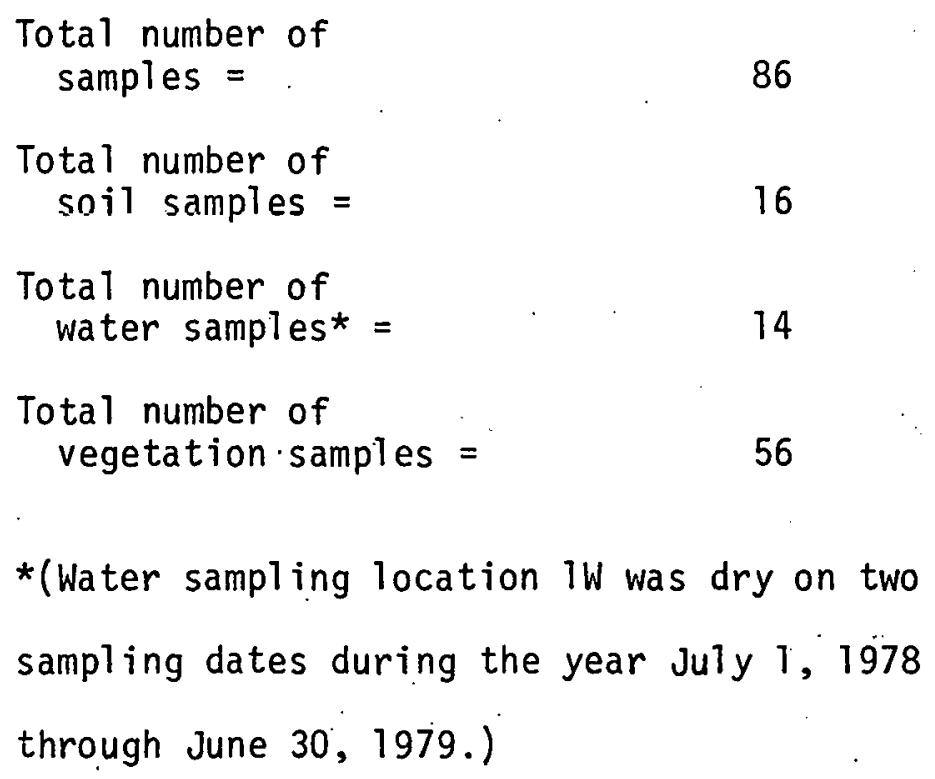


(c) The annual average concentration of gross beta radioactivity for the offsite environmental soil, water and vegetation samples is given in Table V-8. Identification of specific. radionuclides is not routinely carried out as part of this program, but would be conducted if unusual radioactivity levels above natural background were evident. Locations of sampling points relative to the reactor facility are given in Figure $V-3$, and as shown in this figure, most locations are within a 1000 foot radius of the reactor building. In general, samples are collected over a local area having a radius of about 10 feet at the positions indicated in Figure $V-3$. Airborne Gamma Monitoring Program, (offsite):

(a) The offsite airborne gamma monitoring program currently utilizes nineteen stations and each station is considered a sampling location. Presently, eleven stations have a vendor (R.D. Co.) supplied $\mathrm{CaSO}_{4}$ TLD monitor, plus a standard OSU TLD monitoring pack, and two 0-200 mrem gamma pocket dosimeters. Eight. stations have only a standard OSU TLD monitoring pack. In addition, each of the nineteen monitoring stations is included in the ongoing program for measurement of the $\mu R / h r$ exposure rate. 
(b) The TLD's at each airborne gamma monitoring station are changed once every calendar quarter for a total of 44 vendor TLD samples per year, and a total of 228 OSU TLD samples per year (19. stations $\times 3$ TLD chips per station $\times 4$ changes per year $=228$ samples). The two backup monitors (integrating ionization chamber dosimeters) are read every two weeks, which results in approximately 572 individual dosimeter readings each year. There are a total of $26 \mu \mathrm{R} / \mathrm{hr}$ measurements made at each of the nineteen airborne gamma monitoring stations each year for a total of 494 individual measurements annually.

(c) Locations of the nineteen airborne gamma monitoring stations are shown in Table $\mathrm{V}-3$. Like the soil, water, and vegetation sampling locations, most of the airborne gamma monitoring stations dre within a 1000 foot radius of the reactor building. These 10cations generally correspond to the atmosphere (plume) dispersion results mentioned earlier in this report.

The results reported for the airborne gamma monitoring stations are summarized in Table $\mathrm{V}-9$, and are based on the vendor supplied TLD data, the OSU TLD data, 
and results obtained from the $\mu \mathrm{R} / \mathrm{hr}$ measurements. See footnote (8) of Table V-9 for a further explanation of the $\mu R / h r$ data and its application.

This is the second complete year for the vendor supplied TLD monitors, which were substituted for the previous vendor supplied environmental film packs. As already indicated in the next to the last paragraph of section E-1 of this report, OSU is still somewhat reluctant to accept the R.D. Co. TLD data without greater confidence in their $Q A$ and control procedures. As mentioned, we plan to continue a careful assessment of our program in this area to ascertain whether our suspicions are real or not. Future reports will hopefully show closer agreement between the OSU and R.D. Co. TLD results, or will provide data allowing one to state more clearly the reasons for the differences.

Our in-house OSU TLD program was started in 1974 and we believe a number of improvements have been made in the program since that time. There are, however, a few aspects which we continue to improve and some which may still require added refinement. In particular, we are still continuing to study our reported TLD background for the airborne gamma monitoring stations, and still do not believe reported values are always representative of what most stations are experiencing. We increased the number of background stations during 1976, and 
between July 1, 1978 and June 30, 1979 we continued to make a series of direct background measurements with our $\mu \mathrm{R} / \mathrm{hr}$ monitoring equipment (started July 1, 1977) in order to obtain a better profile of the background variation. The results have increased our faith in our background values, but we plan to continue studying this variable.

From our viewpoint, the major purpose of the airborne gamma monitoring stations is to give an indication of general increases or trends in unrestricted area radiation levels which might be 1 inked to Argon-4l released from the OSU TRIGA. Past experience (over the last nine years) has shown that annual results per 10cation vary slightly from year to year. Although the data have not been included in this report, by following the mrem per year history for a single station and comparing the annual mrem total to the curies of Argon-41 emitted for the corresponding year, it becomes evident that there is no consistent pattern to the results, and that other factors must be responsible for the minor mrem per year variations. For example, such variations may be the result of small annual differences in cosmic or terrestrial background, fallout, etc. In any event, the small amount of Argon-41 released annually does not seem to be a significant factor in determining the total mrem per year reported for any particular monitoring 
station. A comparison of the data contained in Table V-9 to past results from these monitoring stations and to the values in footnote (8) of Table V-9 leads us to the conclusion that there has been no meaningful increase in the unrestricted area gamma radiation levels due to Argon-41 released by the OSU TRIGA during the defined reporting period. 


\section{References}

1. Eisenbud, Merril, Environmental Radioactivity, Second Edition, p. 190, Academic Press, New York, NY (1973).

2. U.S. Environmental Protection Agency, "Estimates of Ionizing Radiation Doses in the United States, 1960-2000," ORP/CSD 72-1, Office of Radiation Programs, Rockville, Maryland (1972).

3. U.S. Environmental Protection Agency, "Radiological Quality of the Environment in the United States, 1977," EPA 520/1-77-009, Office of Radiation Programs; Washington, D.C. 20460 (1977). 
Table $V-1$

MONTHLY SUMMARY OF LIQUID WASTE DISCHARGES

FOR THE YEAR JULY 1,1978 THROUGH JUNE $30,1979^{(1)}$

\begin{tabular}{|c|c|c|c|c|c|c|c|}
\hline $\begin{array}{l}\text { Date of } \\
\text { oischarge } \\
\text { (month) }\end{array}$ & $\begin{array}{l}\text { Total Quantity of } \\
\text { Radioactivity } \\
\text { Released (to } \\
\text { sanitary sewer) } \\
\text { (curies) }\end{array}$ & $\begin{array}{l}\text { Detectable } \\
\text { Radionucl ides } \\
\text { in the Waste }\end{array}$ & $\begin{array}{c}\text { Specific Activity for } \\
\text { Each Radioactive } \\
\text { Paterial in Waste } \\
\text { Discharge Where } \\
\text { Released Concentra- } \\
\text { tion After Dilution } \\
\text { was > } 1.0 \times 10^{-7} \mu \mathrm{C} i / \mathrm{cc} \\
\text { (IICi/CC) }\end{array}$ & $\begin{array}{l}\text { Total Curies of } \\
\text { Each Detectable } \\
\text { Radionuclide } \\
\text { Released tn the } \\
\text { Waste } \\
\text { (curies) }\end{array}$ & $\begin{array}{c}\text { Average Concentra- } \\
\text { tion of Released } \\
\text { Aadioactive Material } \\
\text { at Point of Release } \\
\text { (to sanitary sewer) } \\
(\mu \mathrm{C} i / \mathrm{CC})\end{array}$ & $\begin{array}{l}\text { Percent of } \\
\text { Applicable } \\
\text { MPC for } \\
\text { Released } \\
\text { Radioactive } \\
\text { Material } \\
\text { (\%) }\end{array}$ & $\begin{array}{l}\text { Total } \\
\text { Volume of } \\
\text { Effluent, } \\
\text { Including } \\
\text { Diluent } \\
\text { Released } \\
\text { (to sanitary } \\
\text { sewer) } \\
\text { (gallons) }\end{array}$ \\
\hline July-78 & NONE & NONE & NOT APPL. ICABLE. & NONE & NOT APPL ICABLE & NOT APPLICABLE & NONE \\
\hline August-78 & NONE & NONE & NOT APPLICABLE & NONE & NOT APPLICABLE & NOT APPLICABLE & NONE \\
\hline September -78 & NONE & NONE & NOT APPLICABLE & NONE & NOT APPL ICABLE & NOT APPLICABLE & NONE \\
\hline 0ctober-78 & NONE & NONE & NOT APPLICABLE & NONE & NOT APPL ICABLE & NOT APPLICABLE & NONE \\
\hline November-78 & NONE & NONE & NOT APPLICABLE & NONE & NOT APPLICABLE & NOT APPLICABLE & NONE \\
\hline December-78 & $2.30 \times 10^{-5}$ & $\begin{array}{l}{ }^{51} \mathrm{Cr} \\
{ }^{54} \mathrm{Mn} \\
{ }^{58} \mathrm{Co} \\
{ }^{60} \mathrm{Co}_{\mathrm{C}} \\
{ }^{3} \mathrm{H}\end{array}$ & $2.26 \times 10^{-6}$ & $\begin{array}{l}2.21 \times 10^{-8} \\
3.58 \times 10^{-8} \\
4.87 \times 10^{-8} \\
4.48 \times 10^{-7} \\
2.24 \times 10^{-5}\end{array}$ & $2.32 \times 10^{-6}$ & 0.174 & 2620 \\
\hline Jaruary-79 & NONE & NONE & NOT APPLICABLE & NONE & HOT APPL ICABLE & NOT APPLICABLE & NONE \\
\hline February-79 & NONE & NONE & NOT APPLICABLE & NONE & NOT APPLICABLE & NOT APPLICABLE & NONE \\
\hline March-79 & NONE & NONE & NOT APPLICABLE & NONE & NOT APPLICABLE & NOT APPLICABLE & NONE \\
\hline April-79 & NONE & NONE & NOT APPLICABLE & NONE & NOT APPLICABLE & NOT APPLICABLE & NONE \\
\hline May-79 & NONE & NONE & NOT APPLICABLE & NONE & NOT APPL ICABLE & NOT APPL ICABLE & NONE \\
\hline June -79 & NONE & NONE & NOT APPL ICABLE & NONE & NOT APPL ICABLE & NOT APPLICABLE & NONE \\
\hline $\begin{array}{l}\text { Annual } \\
\text { Value }\end{array}$ & $2.30 \times 10^{-5}$ & SEE ABOVE & NOT APPL ICABLE & $2.30 \times 10^{-5}$ & $2.32 \times 10^{-6}$ & 0.174 & $2620^{(2)}$ \\
\hline
\end{tabular}

(1) The OSU operational policy is to subtract only detector background from our water analys is data and not background radioactivity in the Corvalis city water.

(2) Total volume of effluent plus diluent does not take into consideration the additional mixing with approximately 95,000 to 115,000 gallons per year of liquids and sewage normally discharged by the Radiation Center complex into the same santtary sewer system. 
Table $V-\hat{\imath}$

MONTHLY SUMMARY OF GASEOUS WASTE DISCHARGES FOR THE YEAR

JULY 1,1978 THROUGH JUNE 30,1979

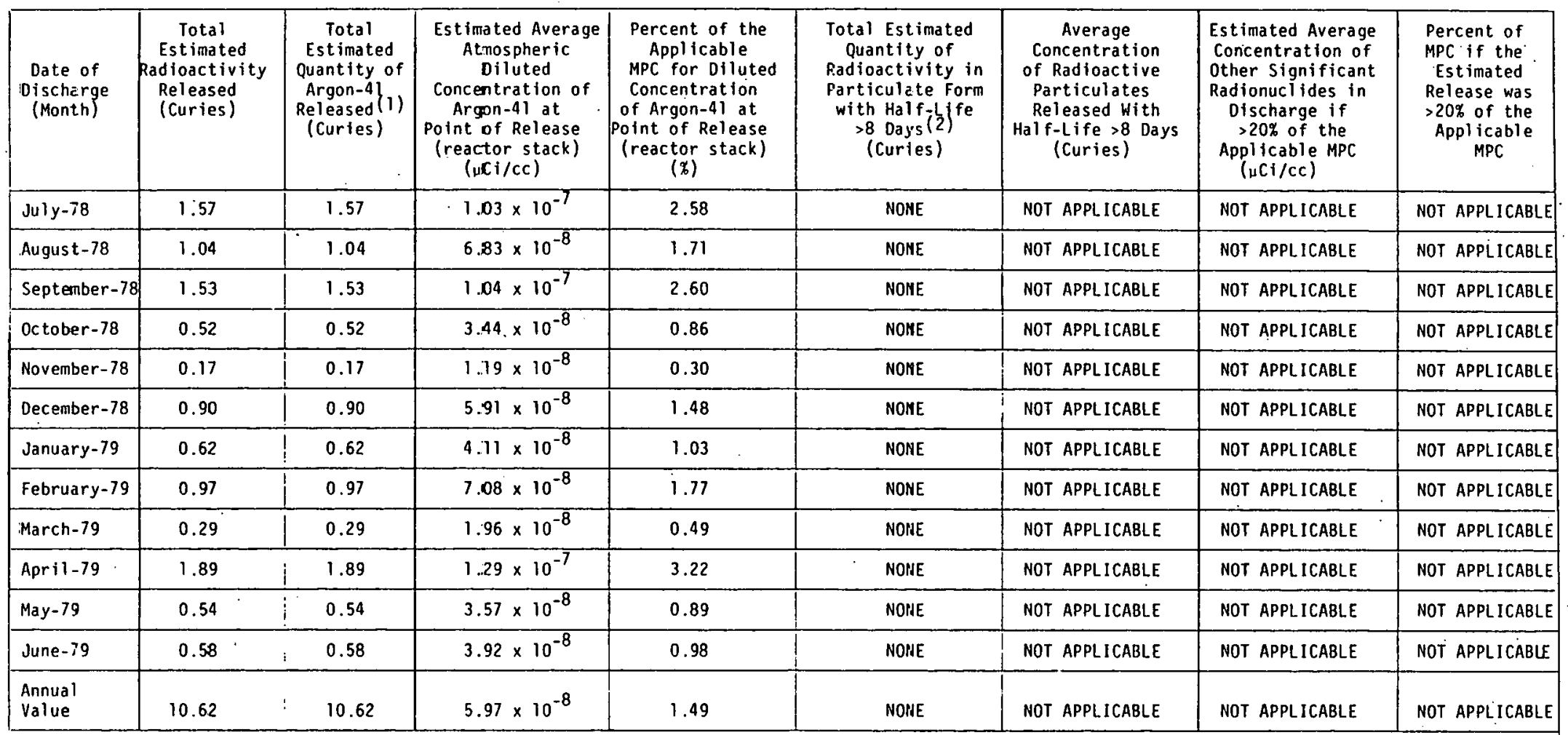

(1) Routine gamma spectroscopy evaluation of the gaseous radioactivity in the stack discharge indicated that it was virtually all Argon-4l.

(2) Evaiuation of the particulate radioactivity in the stack discharge confirmed its origin as naturally occurring radon daughter products, predominantly lead-214 and bismuth-214, not associated with reactor operations. 
Table V-3

ANNUAL SUMMARY OF SOLID WASTE DISCHARGES

FOR THE YEAR JULY 1, 1978 THROUGH JUNE 30, 1979

\begin{tabular}{|c|c|c|c|}
\hline $\begin{array}{c}\text { Total Amount } \\
\text { of Sol id Waste } \\
\text { Packaged } \\
\text { (cubic feet) }\end{array}$ & $\begin{array}{c}\text { Detectable } \\
\text { Radionuclides } \\
\text { in the Waste }\end{array}$ & $\begin{array}{c}\text { Total Quantity } \\
\text { of Radioactivity } \\
\text { in Sol id Waste } \\
\text { (curies) }\end{array}$ & $\begin{array}{c}\text { Dates of Shipment } \\
\text { and Disposition( } 7 \text { ) }\end{array}$ \\
\hline 9.50 & $\begin{array}{l}\text { Cobalt-60 } \\
\text { Iron-59 } \\
\text { Sodium-24 } \\
\text { Manganese-56 } \\
\text { Chromium-51 } \\
\text { Selenium-75 }\end{array}$ & $6.51 \times 10^{-4}$ & $\begin{array}{l}\text { December 12, 1978 } \\
\text { May 22, 1979 }\end{array}$ \\
\hline
\end{tabular}

(1) All solid waste is transferred to our waste disposal service vendor, Nuclear Engineering Company, for burial at their installation at Richland, Washington. Transfer takes place at Oregon State University, Radiation Center, Corvallis, Oregon. 
Table V-4

ANNUAL SUMMARY OF RADIATION EXPOSURE RECEIVED

BY FACILITY PERSONNEL AND VISITORS FOR THE

YEAR JULY 1, 1978 THROUGH JUNE 30, 1979

\begin{tabular}{|l|c|c|c|c|}
\hline \multirow{2}{*}{$\begin{array}{c}\text { Personnel Group } \\
.\end{array}$} & \multicolumn{2}{|c|}{$\begin{array}{c}\text { Average Annual Exposure } \\
\text { for Each Personnel Group }\end{array}$} & \multicolumn{2}{|c|}{$\begin{array}{c}\text { Greatest Individual } \\
\text { Exposure per Personnel Group }\end{array}$} \\
\cline { 2 - 5 } & $\begin{array}{c}\text { Whole Body } \\
\text { (mRem) }\end{array}$ & $\begin{array}{c}\text { Extremities } \\
\text { (mRem) }\end{array}$ & $\begin{array}{c}\text { Whole Body } \\
\text { (mRem) }\end{array}$ & $\begin{array}{c}\text { Extremities } \\
\text { (mRem) }\end{array}$ \\
\hline $\begin{array}{l}\text { Facility Operating } \\
\text { Personnel }\end{array}$ & 8.00 & 208.00 & 30.00 & 680.00 \\
\hline $\begin{array}{l}\text { Key Facility } \\
\text { Research Personnel }\end{array}$ & 0.00 & 82.00 & 0.00 & 450.00 \\
\hline $\begin{array}{l}\text { Facility Visitors: } \\
\text { Film Badges } \\
\text { Pocket Dosimeters }\end{array}$ & 0.00 & $(1)$ & 0.00 & \\
\hline
\end{tabular}

(1) OSU TRIGA reactor policy does not normally allow people in the visitor category to become actively involved in the use or handling of radiation or radioactive materials. Therefore, extremity dosimeters are not normally necessary and no visitor data are available for extremities. 
Table $V-5$

\begin{abstract}
ANNUAL SUMMARY OF RADIATION LEVELS AND
CONTAMINATION LEVELS OBSERVED DURING

ROUTINE RADIATION SURVEYS FOR THE
\end{abstract}

YEAR JULY 1, 1978 THROUGH JUNE 30, 1979

\begin{tabular}{|c|c|c|c|c|c|c|c|}
\hline \multirow{2}{*}{ Location } & \multicolumn{4}{|c|}{$\begin{array}{l}\text { Direct Radiation Levels } \\
\text { (mRem/hr) (Br+neutrons) }\end{array}$} & \multicolumn{3}{|c|}{$\begin{array}{l}\text { Contamination Levels } \\
\left(\mathrm{dpm} / 100 \mathrm{~cm}^{2}\right)(B \gamma)(1)\end{array}$} \\
\hline & \multicolumn{2}{|c|}{ Average } & \multicolumn{2}{|c|}{ Maximum } & \multicolumn{2}{|c|}{ Average } & Maximum \\
\hline Reactor Top & \multicolumn{2}{|c|}{$<1.00$} & \multicolumn{2}{|c|}{100.00} & \multicolumn{2}{|c|}{$\leq 370$} & $\leq 370$ \\
\hline $\begin{array}{l}\text { Sample Handling } \\
\text { Area }\end{array}$ & \multicolumn{2}{|c|}{$<1.00$} & \multicolumn{2}{|c|}{100.00} & \multicolumn{2}{|c|}{$\leq 370$} & $\leq 370$ \\
\hline Reactor Room Floor & \multicolumn{2}{|c|}{$<1.00$} & \multicolumn{2}{|c|}{50.00} & \multicolumn{2}{|c|}{$\leq 370$} & $\leq 370$ \\
\hline Beam Port Facilities & \multicolumn{2}{|c|}{$<1.00$} & \multicolumn{2}{|c|}{50.00} & \multicolumn{2}{|c|}{$\leq 370$} & $\leq 370$ \\
\hline \multirow[t]{3}{*}{ Demineralizer Tank } & \multicolumn{2}{|c|}{$\begin{array}{l}\text { Outside } \\
\text { Shield }\end{array}$} & \multicolumn{2}{|c|}{$\begin{array}{l}\text { Inside } \\
\text { Shield }\end{array}$} & \multicolumn{2}{|c|}{$\begin{array}{l}\text { Outside } \\
\text { Shield }\end{array}$} & $\begin{array}{l}\text { Inside } \\
\text { Shield }\end{array}$ \\
\hline & Avg. & Max. & Avg. & Max. & Avg. & Max. & Avg. Max. \\
\hline & $<1.00$ & 10.00 & $5 . \dot{00}$ & 75.00 & $(2)$ & (2) & $\leq 370 \mid \leq 370$ \\
\hline Class Experiments & \multicolumn{2}{|c|}{$\leq 1.00$} & \multicolumn{2}{|c|}{215.00} & \multicolumn{2}{|c|}{$\leq 370$} & $\leq 370$ \\
\hline
\end{tabular}

(1) No contamination was found at the designated locations during the entire reporting period. The $370 \mathrm{dpm} / 100 \mathrm{~cm}^{2}$ value used in this table is based on the normal beta efficiency and a net count rate equal to the normal background counting rate for the portable survey meters routinely used in the field to screen for radioactive contamination (i.e., field measurements would normally have to show a gross counting rate equal to twice the normal background counting rate before contamination would be considered present). However, in addition to normal field screening, smears suspected of containing removable radioactive contamination are routinely counted in a more sensitive radiation detection system. Based on usual counting times, a normal instrument counting efficiency and a normal background counting rate, during the current reporting period such a detection system typically provided a lower limit of detection (LLD) at $95 \%$ confidence of approximately 11-12 dpm for the radionuclides normally expected to be on the smears. Smearing efficiency for radioactivity removal is conservatively assumed to be $210 \%$, and positive smear results would usually be multiplied by 10 before final conversion to $\mathrm{dpm} / 100 \mathrm{~cm}^{2}$.

(2) Not an applicable measurement. 


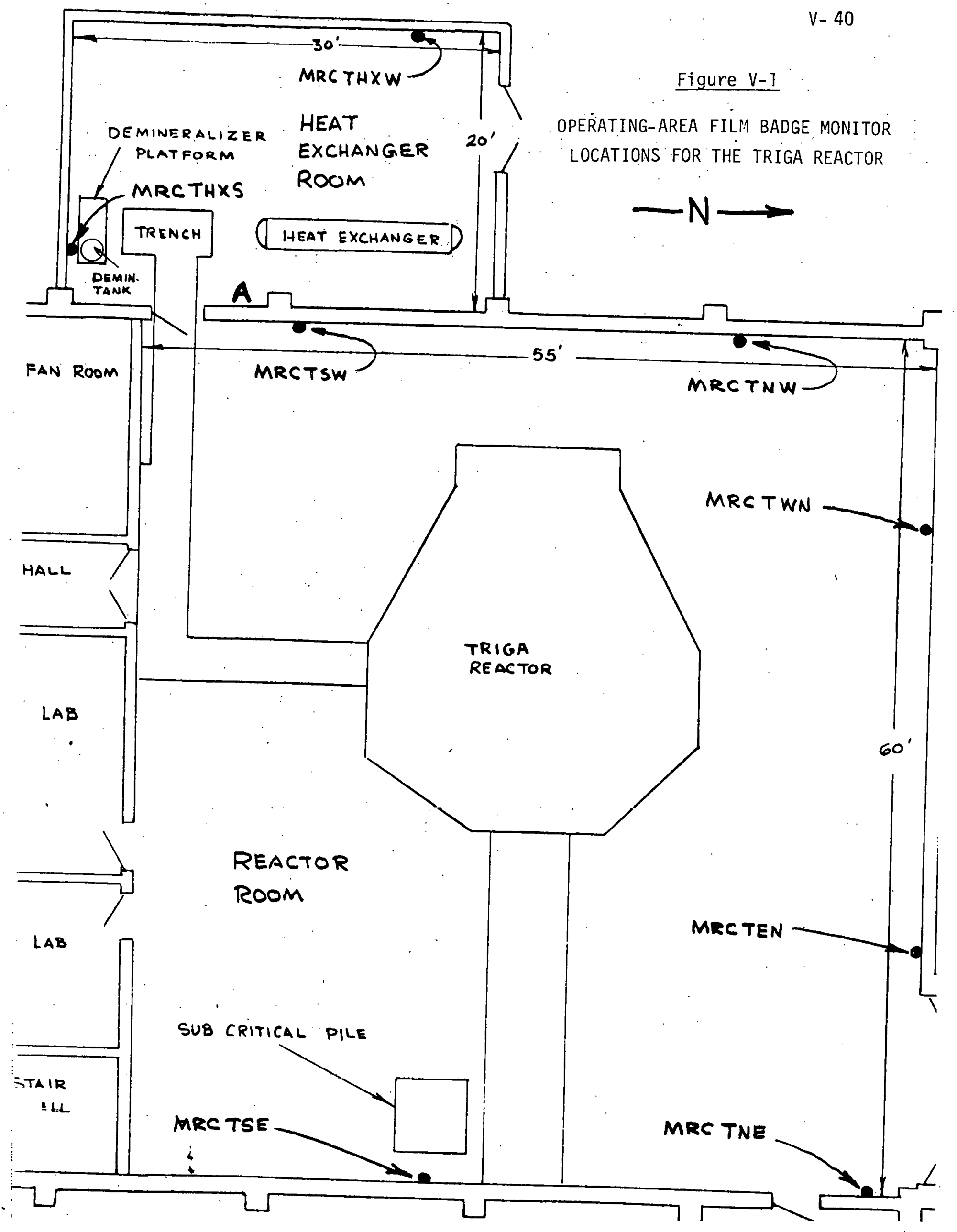


Figure $V-2$

AREA RADIATION MONITOR LOCATIONS FOR THE

TRIGA AND AGN REACTORS, AND THE TRIGA REACTOR AREA FENCE

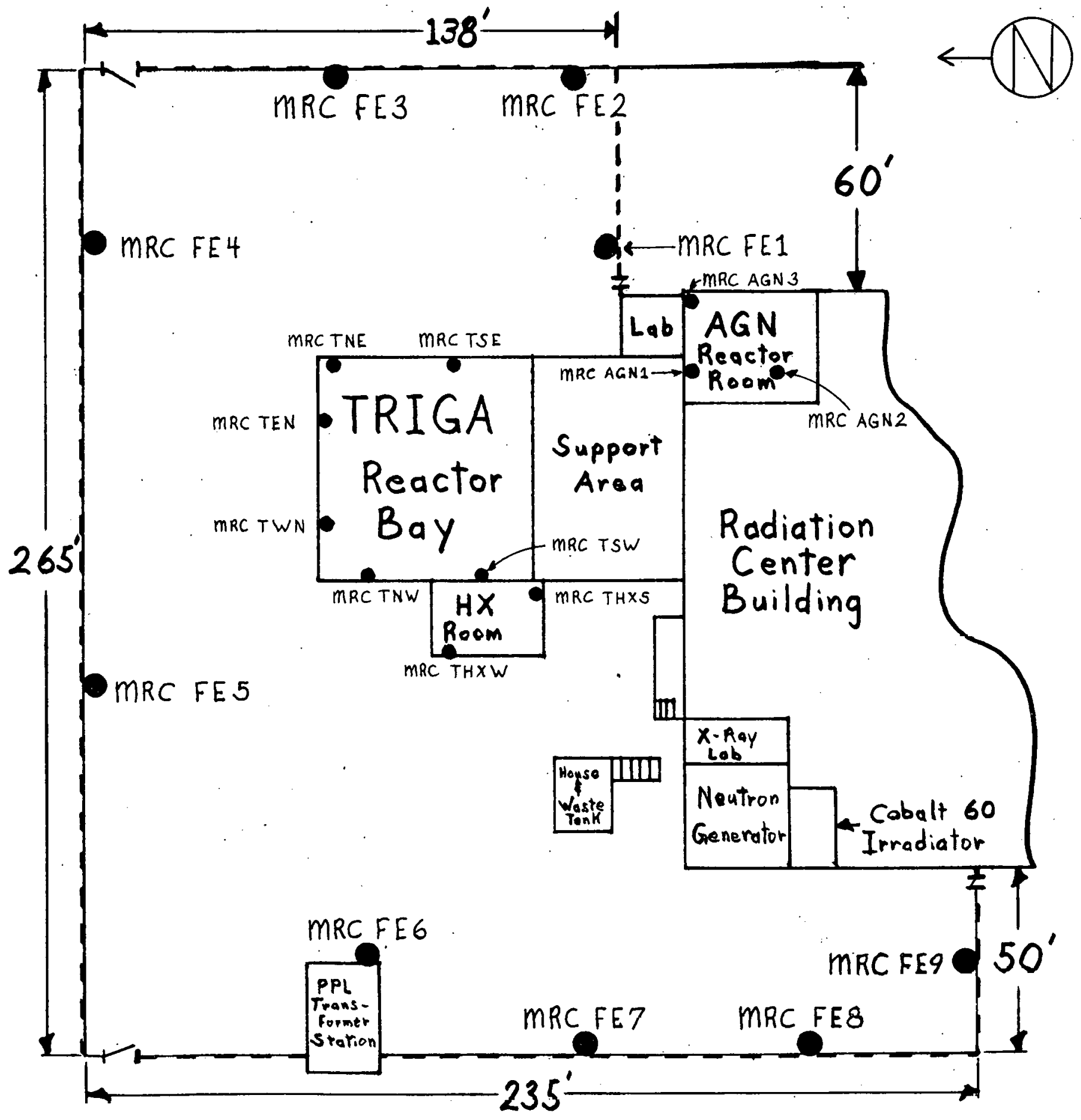


Table V-6

TOTAL DOSE EQUIVALENT RECORDED ON OPERATING-AREA FILM BADGE 'MONITORS LOCATED INSIDE THE TRIGA REACTOR FACILITY FOR THE YEAR JULY 1,1978 THROUGH JUNE 30,1979

Location(1)

MRCTNE

MRCTSE

MRCTSW

MRCTNW

MRCTWN

MRCTEN

MRCTHXS

MRCTHXW
Total Recorded mRem for the Year July 1, 1978 Through June $30,1979(2)(5)$
0

$0(3)$

0

15

0

0

$0(4)$

0

(1) These locations do not represent radiation exposure through an exterior wall directly into an unrestricted area.

(2) Totals do not include natural background contribution.

(3) Film badge opposite subcritical pile. Shield for subcritical pile completed February 23, 1972 .

(4) Film badge opposite particulate filter for reactor primary water cleanup system. Shield around this filter was completed July 10, 1972.

(5) These area film badge monitors are exchanged on a monthly interval, and the total mRem value reflects the summation of results from 12 different film packets. 
Table V-7

TOTAL DOSE EQUIVALENT AT THE TZIGA REACTOR AREA FENCE FOR THE YEAR JULY 1,1978 THROUGH JUNE 30,1979

Total Recorded mRem for the Year July 1 , rg78 Through Jine 30

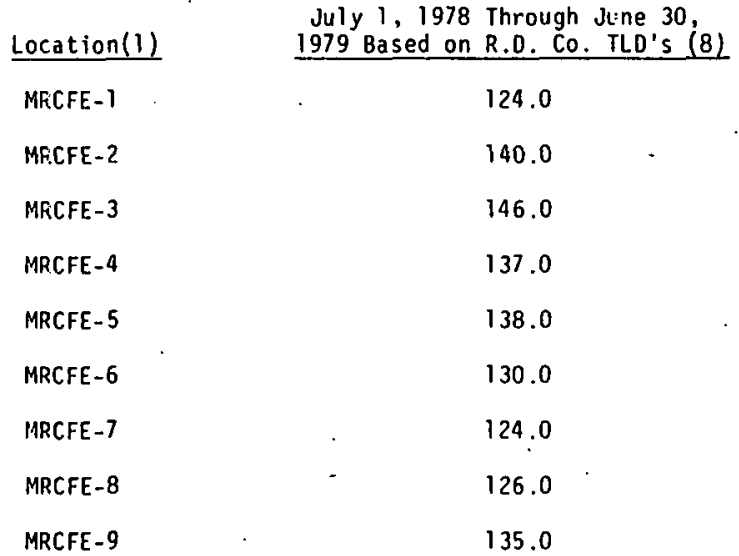

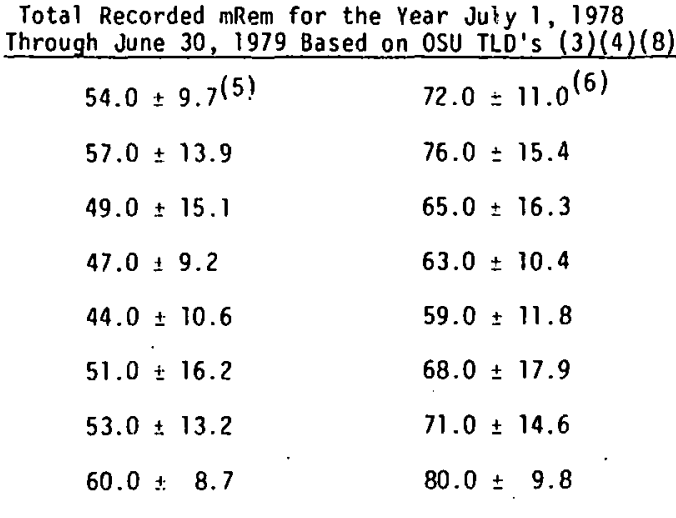

\begin{tabular}{l} 
Total Calculated mRem for the Year \\
July 1, 1978 Through June 30, \\
1979 Based on the Annual Average \\
uR/hr Exposure Rate Measured \\
at Each Location(4)(7) \\
\hline $71.0 \pm 20.0$ \\
$75.0 \pm 17.0$ \\
$74.0 \pm 20.0$ \\
$77.0 \pm 22.0$ \\
$62.0 \pm 22.0$ \\
$63.0 \pm 28.0$ \\
$68.0 \pm 23.0$ \\
$63.0 \pm 14.0$ \\
$64.0 \pm 15.0$
\end{tabular}

(1) The TRIGA reactor area fence was installed September 15, 1972.

(2) Radiation Detection Company (R.D. Co.), Mt. View, California, TLD totals include an annual natural background contribution of 115.0 mRem for the reporting period.

(3) 0 SU fence TLD totals include a measured three calendar quarter natural background contribution of $52.0 \pm 13.1$ mRem for data in the left column (see footnote 5), and a calculated four calendar quarter annual natural background contribution of $70.0 \pm 14.9$ mRem for data in the right column (see footnotes 5 and 6 )

$(4)_{+}$values represent the standard deviation at the $95 \%$ confidence level.

(5) Total mRem values shown in this column are based on data from only three calendar quarters. During the 1978-79 reporting period, one quarter's data (the third quarter of 1978, which is the first quarter of the current reporting period) were completely invalidated due to TLO equipment mal function.

(6) Total mRem values shown in this column are estimated annual (four calendar quarter) values for each location. The-estimated values were derived by summing the three quarters of measured data and a fourth value obtained by averaging the three quarters of measured data. The latter value (the average of the three measured quarters) was used to represent the best estimate of the missing quarter's data for the $1978-79$ reporting period.

(7)

The annual average microroentgen ( 1 R R) per hour exposure rate for each location was determined by averaging 26 separate $\mu R / h r$ measurements taken at 2 week intervals throughout the year. The total mRem for the period was calculated by multiplying this average $u R / h r$ value by 8760 hours per year and then converting microroentgens to millirem. Normal $\mathrm{uR} / \mathrm{hr}$ values for the U.S. (terrestrial plus cosmic radiation) range between about 7.0 and $11.0 \mu \mathrm{R} / \mathrm{hr}$ (Ref. T) excluding areas of unusually high natural radioactivity). These exposure rates correspond to annual dose equivalent totals of about 59 to 93 mRem per year. The U.S. EPA (Ref. 2,3) estimates the total annual terrestrial plus

(8) cosmic dose equivalent for Oregon to be about 110 mRem per year. 
FIGURE V-3

MONITORING STATIONS FOR

THE OSU TRIGA REACTOR,

JANUARY 6,1976

THROUGH

JunE 30,1979

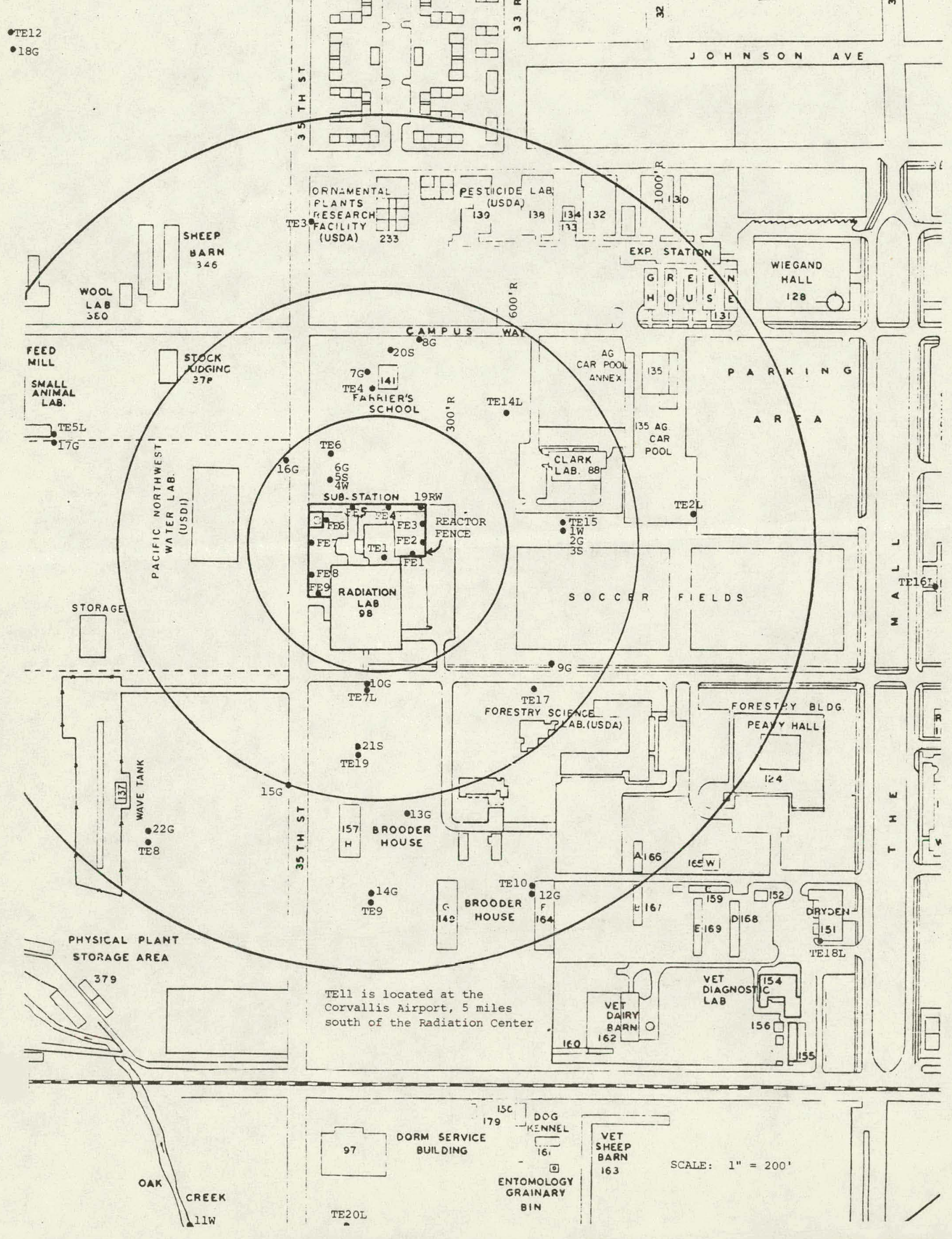


Table V-8

ANNUAL AVERAGE CONCENTRATIONS OF GROSS BETA RADIOACTIVITY

FOR OFFSITE ENVIRONMENTAL SOIL, WATER, AND VEGETATION

SAMPLES FOR THE YEAR JULY 1,1978 THROUGH JUNE 30,1979

Sample Identification Number, Type \& Reporting Units

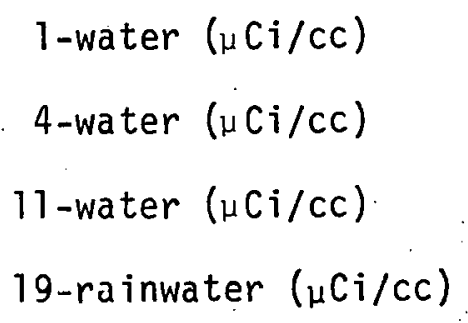

Annual Average Concentration of Gross Beta Radioactivity (minus $\left.{ }^{3} \mathrm{H}\right)(1)(2)(3)$

$5.01 \times 10^{-8} \pm 2.28 \times 10^{-8(4)}$

$1.12 \times 10^{-7} \pm 4.17 \times 10^{-8}$

$7.18 \times 10^{-8} \pm 1.67 \times 10^{-8}$

$6.27 \times 10^{-8} \pm 1.75 \times 10^{-8}$

$5.43 \times 10^{-5} \pm 2.33 \times 10^{-6}$

$4.44 \times 10^{-5} \pm 2.00 \times 10^{-6}$

$5.26 \times 10^{-5} \pm 2.15 \times 10^{-6}$

$6.90 \times 10^{-5} \pm 2.87 \times 10^{-6}$

$1.28 \times 10^{-4} \pm 2.72 \times 10^{-6}$

$9.31 \times 10^{-5} \pm 2.98 \times 10^{-6}$

$1.67 \times 10^{-4} \pm 2.86 \times 10^{-6}$ 
Sample Identification Number, Type \& Reporting Units

8-grass $\left(\frac{\mu C i}{\text { gram of dry ash }}\right)$

9-grass $\left(\frac{\mu \mathrm{Ci}}{\text { gram of dry ash }}\right)$

10-grass $\left(\frac{\mu C i}{\text { gram of dry ash }}\right)$

12-grass $\left(\frac{\mu C i}{\text { gram of dry ash }}\right)$

13-grass $\left(\frac{\mu C i}{\text { gram of dry ash }}\right)$

14-grass $\left(\frac{\mu C i}{\text { gram of dry ash }}\right)$

$15-$ grass $\left(\frac{\mu \mathrm{Cj}}{\text { gram of dry ash }}\right)$

16 -grass $\left(\frac{\mu \mathrm{Ci}}{\text { gram of dry ash }}\right)$

17 -grass $\left(\frac{\mu C i}{\text { gram of dry ash }}\right)$

18-grass $\left(\frac{\mu C i}{\text { gram of dry ash }}\right)$

22-grass $\left(\frac{\mu \mathrm{Ci}}{\text { gram of dry ash }}\right)$
Annual Average Concentration of Gross Beta Radioactivity (minus $\left.{ }^{3} \mathrm{H}\right)(1)(2)(3)$

$1.41 \times 10^{-4} \pm 2.75 \times 10^{-6}$

$1.20 \times 10^{-4} \pm 2.34 \times 10^{-6}$

$1.48 \times 10^{-4} \pm 3.15 \times 10^{-6}$

$1.49 \times 10^{-4} \pm 2.76 \times 10^{-6}$

$1.26 \times 10^{-4} \pm 2.92 \times 10^{-6}$

$9.59 \times 10^{-5} \pm 2.85 \times 10^{-6}$

$9.11 \times 10^{-5} \pm 2.38 \times 10^{-6}$

$9.03 \times 10^{-5} \pm 2.53 \times 10^{-6}$

$1.46 \times 10^{-4} \pm 2.88 \times 10^{-6}$

$1.57 \times 10^{-4} \pm 2.96 \times 10^{-6}$

$1.76 \times 10^{-4} \pm 3.29 \times 10^{-6}$

(1) \pm values represent the standard deviation at the $95 \%$ confidence level.

(2)Annual average concentrations were calculated using sample results which exceeded the lower limit of detection (LLD), except that sample results which were $\leq$ the LLD were averaged in at the corresponding LLD concentration. 
(3) For this report, the lower 1 imit of detection (LLD) has been defined as the smallest concentration of radioactive material in a sample that has a $95 \%$ probability of being detected ( 4.66 times the standard deviation of the average background value obtained with a blank sample, provided the relative standard deviation of the background [the coefficient of variation] is less than 25\%). For the year July 1, 1978 through June 30,1979 , the LLD for gross $\beta$ in water samples averaged $2.20 \times 10^{-8} \mu \mathrm{Ci} / \mathrm{CC}$ and ranged between $2.37 \times 10^{-8} \mu \mathrm{Ci} / \mathrm{CC}$ and $2.02 \times 10^{-8}$ $\mu \mathrm{C} i / c C$. For gross $B$ in vegetation samples the $L L D$ averaged $5.70 \times 10^{-6}$ $\mu \mathrm{Ci} / \mathrm{gm}$ and ranged between $1.12 \times 10^{-5} \mu \mathrm{Ci} / \mathrm{gm}$ and $8.97 \times 10^{-6} \mu \mathrm{Ci} / \mathrm{gm}$. For gross $\beta$ in soil samples the LLD averaged $5.77 \times 10^{-6} \mu \mathrm{Ci} / \mathrm{gm}$ and ranged between $1.20 \times 10^{-5} \mu \mathrm{Ci} / \mathrm{gm}$ and $6.13 \times 10^{-6} \mu \mathrm{Ci} / \mathrm{gm}$.

(4) This sample location was dry for two calendar quarters during the reporting period (the third quarter 1978 and the second quarter 1979). Therefore, no samples were collected for these intervals. 
Table $V-9$

ANNUAL TOTALS FOR OFFSITE AIRBORNE. GAMMA MONITORING STATIONS FOR

THE YEAR JULY 1, 1978 THROUGH JUNE 30, 1979

\begin{tabular}{|c|c|}
\hline Monitoring Station & $\begin{array}{l}\text { Total Recorded mRem for the Year } \\
\text { July } 1 \text {, } 1978 \text { Through June } 30,1979 \\
\text { Based on R.0. Co. TLD's(1)(9) } \\
\end{array}$ \\
\hline MRCTE-2L & $\ldots-(2)$ \\
\hline MRCTE-3 & $138.0(3)$ \\
\hline MRCTE-4 & 133.0 \\
\hline MRCTE-5L & $\ldots$ \\
\hline MRCTE- 6 & 150.0 \\
\hline MRCTE-7L & \\
\hline MRCTE-8 & 138.0 \\
\hline MRCTE-9 & 152.0 \\
\hline MRCTE-10 & 136.0 \\
\hline MRCTE-11 & 119.0 \\
\hline MRCTE-12 & 150.0 \\
\hline MRCTE-13L & $\cdots$ \\
\hline MRCTE-14L & -..... \\
\hline MRCTE-15 & 140.0 \\
\hline MRCTE-16L & \\
\hline MRCTE-17 & 145.0 \\
\hline MRCTE-18L & $\ldots$ \\
\hline MRCTE-19 & 156.0 \\
\hline MRCTE-20L & $\ldots$ \\
\hline
\end{tabular}

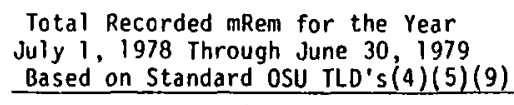

Based on Standard OSU TLD's (4)(5)(9)

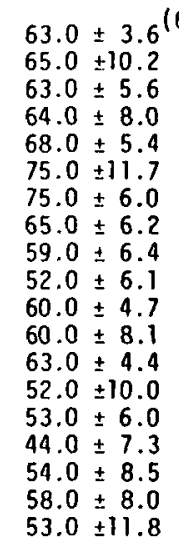

$84.0 \pm 4.1(7)$
$87.0 \pm 11.5$
$34.0 \pm 6.5$
$85.0 \pm 9.1$
$91.0 \pm 6.2$
$100.0 \pm 13.2$
$100.0 \pm 6.7$
$87.0 \pm 7.0$
$79.0 \pm 7.3$
$69.0 \pm 7.1$
$80.0 \pm 5.4$
$80.0 \pm 8.9$
$84.0 \pm 5.0$
$69.0 \pm 11.3$
$71.0 \pm 6.9$
$59.0 \pm 8.1$
$72.0 \pm 9.6$
$77.0 \pm 8.9$
$71.0 \pm 13.6$

Total Calculated mRem for the Year July 1 , 1978 Through June 30 ,

\begin{tabular}{l}
$\mu R /$ hr Exposure Rate Measured at \\
\hline
\end{tabular} R/hr Exposure Rate Measured Each Location(5)(8)

$$
\begin{aligned}
& 62.0 \pm 22.0 \\
& 76.0 \pm 12.0 \\
& 70.0 \pm 15.0 \\
& 73.0 \pm 18.0 \\
& 79.0 \pm 16.0 \\
& 75.0 \pm 16.0 \\
& 80.0 \pm 20.0 \\
& 86.0 \pm 29.0 \\
& 66.0 \pm 16.0 \\
& 60.0 \pm 16.0 \\
& 86.0 \pm 19.0 \\
& 70.0 \pm 17.0 \\
& 75.0 \pm 21.0 \\
& 82.0 \pm 15.0 \\
& 77.0 \pm 18.0 \\
& 68.0 \pm 13.0 \\
& 69.0 \pm 13.0 \\
& 83.0 \pm 14.0 \\
& 68.0 \pm 20.0
\end{aligned}
$$

(1) Radiation Detection Company (R.D. Co.), Mt. View, California, TLo totals irclude an annual natural background contribution of 115.0 mRem

(2) Monitoring stations coded with an "L" contain one standard OSU TLD monitoring pack only. (No. R.D. Co. TLD pack.)

(3) Monitoring stations not coded with an "L" contain one R.D. Co. TLD monitoring pack, two 0-200 mRem gamma pocket dosimeters and one standard OSU TLO monitoring pack.

(4) OSU offsite airborne gamma TLO totals include a measured three calendar quarter natural background contribution of $45.0 \pm 11.1 \mathrm{mRem}$ for data in the left column (see footnote 6), and a calculated four calendar quarter annual natural background contribution of $60.0 \pm 12.5 \mathrm{mRem}$ for data in the right column (see footnotes 6 and 7 ).

(5) \pm values represent the standard deviation at the $95 \%$ confidence level.

(6) Total mRem values shown in this column are based on data from only three calendar quarters. During the 1978-79 reporting period, one quarter's data (the third quarter of 1978, which is the first quarter of the current reporting period) were completely invalidated due to TLD equipment mal function.

(7) Total mRem values shown in this column are estimated annual (four calendar quarter) values for each location. The estimated values were derived by summing the three quarters of measured data and a fourth value obtained by averaging the three quarters of measured data. The latter value (the average of the three measured quarters) was used to represent the best estimate of missing quarter's data for the $1978-79$ reporting period.

(8) The annual average microroentgen ( $\mu R$ ) per hour exposure rate for each location was determined by averaging 26 separate $\mu R / h r$ measurements taken at 2 week intervals throughout the year. The total mRem for the period was calculated by multiplying this average $\mu R / h r$ value by 8760 hours per year and then converting microroentgens to millirem. Normal uR/hr values for the U.S. (terrestrial plus cosmic radiation) range between about 1.0 and $11.0 \mathrm{w} / \mathrm{hr}$ (Ref. to annual dose equivalent totals of about 59 to $93 \mathrm{mRem}$ per year. The U.S. EPA (Ref. 2,3) estimates the total annual terrestrial plus

(9) TLD monitoring packets are exchanged on a quarterly interval. 